\title{
Antibacterial nucleoside-analog inhibitor of bacterial RNA polymerase: pseudouridimycin
}

Sonia I. Maffioli ${ }^{1,2, *}$, Yu Zhang ${ }^{3, *}$, David Degen ${ }^{3, *}$, Thomas Carzaniga ${ }^{4}$, Giancarlo Del Gatto ${ }^{1}$, Stefania

Serina $^{1,2}$, Paolo Monciardini ${ }^{1,2}$, Carlo Mazzetti ${ }^{1}$, Paola Guglierame ${ }^{5}$, Gianpaolo Candiani ${ }^{2}$, Alina Iulia Chiriac $^{6}$, Giuseppe Facchetti ${ }^{2}$, Petra Kaltofen ${ }^{2}$, Hans-Georg Sahl ${ }^{6}$, Gianni Dehò ${ }^{4}$,

Stefano Donadio ${ }^{1,2, * *}$ and Richard H. Ebright ${ }^{3, * *}$

${ }^{1}$ NAICONS Srl, 20139 Milan, Italy

${ }^{2}$ Vicuron Pharmaceuticals, 21040, Gerenzano, Italy

${ }^{3}$ Waksman Institute and Department of Chemistry, Rutgers University, Piscataway NJ 08854, USA

${ }^{4}$ Department of Bioscience, University of Milan, 20122 Milan, Italy

${ }^{5}$ NeED Pharma Srl, 20139 Milan, Italy

${ }^{6}$ University of Bonn, D-53012 Bonn, Germany

*Contributed equally

**Corresponding authors: sdonadio@naicons.com; ebright@,waksman.rutgers.edu 
There is an urgent need for new antibacterial drugs effective against bacterial pathogens resistant to current drugs ${ }^{1-2}$. Nucleoside-analog inhibitors (NAIs) of viral nucleotide polymerases have had transformative impact in treatment of $\mathrm{HIV}^{3}$ and $\mathrm{HCV}^{4}$. NAIs of bacterial RNA polymerase (RNAP) potentially could have major impact on treatment of bacterial infection, particularly because functional constraints on substitution of RNAP nucleoside triphosphate (NTP) binding sites ${ }^{4-5}$ could limit resistance emergence ${ }^{4-5}$. Here we report the discovery, from microbial extract screening, of an NAI that inhibits bacterial RNAP and exhibits antibacterial activity against a broad spectrum of drug-sensitive and drug-resistant bacterial pathogens: pseudouridimycin (PUM). PUM is a novel microbial natural product consisting of a formamidinylated, N-hydroxylated Gly-Gln dipeptide conjugated to 6'-amino-pseudouridine. PUM potently and selectively inhibits bacterial RNAP in vitro, potently and selectively inhibits bacterial growth in culture, and potently clears infection in a mouse model of Streptococcus pyogenes peritonitis. PUM inhibits RNAP through a binding site on RNAP (the "i+1" NTP binding site) and mechanism (competition with UTP for occupancy of the "i+1" NTP binding site) that differ from those of the RNAP inhibitor and current antibacterial drug rifampin (Rif). PUM exhibits additive antibacterial activity when co-administered with Rif, exhibits no cross-resistance with Rif, and exhibits a spontaneous resistance rate an order-ofmagnitude lower than that of Rif. The results provide the first example of a selective NAI of bacterial RNAP, provide an advanced lead compound for antibacterial drug development, and provide structural information and synthetic routes that enable lead optimization for antibacterial drug development.

We screened a library of 3000 Actinobacterial $^{6}$ and fungal culture extracts for inhibition of RNAP, and we identified two extracts that inhibited bacterial RNAP (E. coli RNAP) but did not inhibit a structurally unrelated bacteriophage RNAP (SP6 RNAP) and did not contain a previously characterized inhibitor of bacterial RNAP (see Methods). Fractionation of the two extracts by reversed-phase chromatography and structure elucidation of active components by mass spectrometry and 
multidimensional NMR spectrometry revealed that the extracts contained the same novel active component: pseudouridimycin (PUM; Fig. 1a; Extended Data Figs. 1-2).

PUM selectively inhibits bacterial RNAP (IC50 =0.1 $\mu \mathrm{M}$; selectivity $>4$ - to $>500$-fold; Fig. $1 \mathrm{~b}$; Extended Data Table 1; Extended Data Fig. 3), selectively inhibits bacterial growth (IC50 = 2 to $16 \mu \mathrm{M}$; selectivity $>6$ - to $>60$-fold; Fig. 1c), and clears infection in vivo in a mouse Streptococcus pyogenes peritonitis model (ED50 = $9 \mathrm{mg} / \mathrm{kg}$; Fig. 1c; Extended Data Table 2). PUM exhibits antibacterial activity against both Gram-positive and Gram-negative bacteria and against both drug-sensitive and drug-resistant bacterial strains, including rifamycin-, $\beta$-lactam-, fluoroquinolone- macrolide-, tetracycline-, aminoglycoside-, lincosamide-, chloramphenicol-, oxazolidinone-, trimethoprim-, glycopeptide-, lipopeptide-, mupirocin-, and multi-drug-resistant strains (Fig. 1c).

PUM exhibits no cross-resistance with the classic RNAP inhibitor Rif (Figs. 1b-c,e), exhibits additive antibacterial activity when co-administered with Rif (Fig. 1f), and exhibits spontaneous resistance rates an order-of-magnitude lower than those of Rif (Fig. 2a), suggesting that PUM inhibits RNAP through a binding site and mechanism different from those of Rif.

Gene sequencing indicates that PUM-resistant mutants contain mutations in the rpoB gene (encodes RNAP $\beta$ subunit) or the $r p o C$ gene (encodes RNAP $\beta^{\prime}$ subunit), confirming that RNAP is the functional cellular target of PUM (Fig. 2b; Extended Data Fig. 4a-b). In the Gram-positive bacterium $S$. pyogenes, substitutions conferring $\geq 4 x$ PUM-resistance are obtained at four sites: $\beta$ residues 565, 681, and 684, and $\beta^{\prime}$ residue 786 (numbered as in E. coli RNAP; Fig. 2b). In the Gram-negative bacterium $E$. coli, substitutions conferring PUM-resistance are obtained at two sites: $\beta$ residues 565 and 681 (Extended Data Fig. 4a-b). The number of sites of substitutions conferring PUM-resistance is an order-of-magnitude lower than the number of sites of substitutions conferring Rif-resistance ( 2 to 4 vs. $25^{7-8}$ ), consistent with, and accounting for, the observation that spontaneous resistance rates for PUM are an order-of-magnitude lower than those for Rif (Fig. 2a). 
Mapping the sites of substitutions conferring PUM resistance onto the three-dimensional structure of bacterial RNAP shows that the sites form a single discrete cluster ("PUM target"; Fig. 2c; Extended Data Fig. 4d). The PUM target is located within the RNAP active-center region and overlaps the RNAP active-center i+1 NTP binding site (Fig. 2c; Extended Data Fig. 4d), suggesting that PUM inhibits RNAP by interfering with function of the $i+1$ site. The PUM target is different from, and does not overlap, the Rif target (Fig. 2d; Extended Data Fig. 4e) ${ }^{7-9}$, consistent with, and accounting for, the observation that PUM does not share cross-resistance with Rif (Figs. 1b-c,e, 2e; Extended Data Fig. 4f-g) and the observation that PUM and Rif exhibit additive antibacterial activity (Fig. 1f). The PUM target also is different from, and does not overlap, the targets of the RNAP inhibitors lipiarmycin (Lpm) ${ }^{10-11}$, myxopyronin $(\mathrm{Myx})^{11-13}$, streptolydigin $(\mathrm{Stl})^{14-15}, \mathrm{CBR} 703(\mathrm{CBR})^{16-17}$, and salinamide $(\mathrm{Sal})^{18}(\mathrm{Fig} .2 \mathrm{~d}$; Extended Data Fig. 4e), and, correspondingly, PUM does not exhibit cross-resistance with Lpm, Myx, Stl, CBR703, and Sal (Fig. 2e; Extended Data Fig. 4f,h-1). The PUM target partly overlaps the target for the RNAP inhibitor GE23077 (GE; Extended Data Fig. 4m) , and, correspondingly, PUM exhibits partial cross-resistance with GE (Extended Data Fig. 4n).

The observation that PUM is an NAI that has the same Watson-Crick base-pairing specificity as UTP (Fig. 1a) and the observation that the PUM target overlaps the RNAP i+1 NTP binding site (Fig. 2b; Extended Data Fig. 4a) suggest the hypothesis that PUM functions as an NAI that competes with UTP for occupancy of the RNAP i+1 NTP binding site. Five biochemical results support this hypothesis. First, PUM inhibits transcription by inhibiting nucleotide addition (Extended Data Fig. 5). Second, high concentrations of UTP--but not high concentrations of GTP, ATP, or CTP--overcome transcription inhibition by PUM (Fig. 3a). Third, PUM inhibits transcription only on templates that direct incorporation of U (Fig. 3b). Fourth, in single-nucleotide-addition transcription reactions, PUM inhibits incorporation of $\mathrm{U}$, but not G, A, or C (Fig. 3c). Fifth, in multiple-nucleotide-addition transcription reactions, PUM inhibits incorporation of U, but not G, A, or C (Fig. 3d). The results in Fig. 3c-d further establish that transcription inhibition by PUM not only requires a template position that directs incorporation of $U$, but also strongly prefers a preceding template position that directs incorporation of $\mathrm{G}, \mathrm{A}$, or $\mathrm{U}$. We conclude 
that PUM functions as an NAI that competes with UTP at positions that direct incorporation of U preceded by positions that direct incorporation of $\mathrm{G}, \mathrm{A}$, or $\mathrm{U}$.

To define the structural basis of transcription inhibition by PUM, we determined a crystal structure of a transcription initiation complex containing PUM (RPo-GpA-PUM; Fig. 4a) and, for comparison, a crystal structure of a corresponding transcription initiation complex containing CMPcPP (RPo-GpA-CMPcPP; Fig. 4b). The results establish that PUM is an NAI that competes for occupancy of the $\mathrm{i}+1$ site (Fig. 4). PUM binds to the $\mathrm{i}+1$ site (Fig. 4a). The PUM base makes Watson-Crick H-bonds with a DNA template-strand A in a manner equivalent to an NTP base; the PUM sugar moiety makes interactions with the $\mathrm{i}+1$ site in a manner nearly equivalent to an NTP sugar; the PUM glutamine moiety makes interactions that mimic interactions made by an NTP triphosphate; and the PUM N-hydroxy and guanidinyl moieties interact with the RNA nucleotide base-paired to the preceding template position (RNA 3'-nucleotide), with the N-hydroxy donating an H-bond to the 3'-OH of the RNA 3'-nucleotide, and the guanidinyl moiety donating one H-bond to the 5'-phosphate of the RNA 3'-nucleotide and another to the base of the RNA 3'-nucleotide (Fig. 4a).

The structure of the PUM-inhibited complex accounts for the observed specificity of inhibition for template positions that direct incorporation of $U$ preceded by template positions that direct incorporation of G, A, or U. The Watson-Crick base pair by the PUM base moiety provides absolute specificity for a position directing incorporation of U (Fig. 4a). The H-bond donated by the PUM guanidinyl moiety with the base of the RNA 3'-nucleotide confers specificity for a preceding position directing incorporation of $\mathrm{G}, \mathrm{A}$, or $\mathrm{U}$ (each of which contains an $\mathrm{H}$-bond acceptor at the appropriate position; Fig. 4a).

The structure also explains the selectivity of transcription inhibition by PUM. All RNAP residues contacted by PUM are highly conserved across Gram-positive and Gram-negative bacterial RNAP (Extended Data Fig. 6), accounting for the inhibition of both Gram-positive and Gram-negative bacterial RNAP. In contrast, four RNAP residues important for PUM are not conserved in human RNAP I, II, and 
III ( $\beta$ residues 677, 681, and 684, and $\beta^{\prime}$ residue 932; Extended Data Fig. 6), accounting for selectivity for bacterial RNAP over human RNAP I, II, and III.

The structure also explains the small size of the PUM resistance spectrum (four residues in S. pyogenes RNAP; two residues in E. coli RNAP; Fig. 2b; Extended Data Fig. 4a-b). PUM makes direct contacts with RNAP residues at which PUM-resistant substitutions are obtained (Extended Data Fig. 6). However, PUM also makes direct contacts with ten other RNAP residues that comprise functionally critical residues of the RNAP active center that cannot be substituted without compromising RNAP activity $^{5 ; 19-23}$, and thus which cannot be substituted to yield viable resistant mutants ${ }^{5}$ (Fig. 4a). We infer that PUM interacts with a "privileged target" for which most residues (10-12 of 14 residues) have functional constraints that limit substitution to yield viable resistant mutants. Similar results have been reported for the RNAP inhibitor GE, a non-nucleoside-analog inhibitor that binds to the RNAP $\mathrm{i}$ and $\mathrm{i}+1$ $\operatorname{sites}^{5}$ and that exhibits a small target-based resistance spectrum ${ }^{5}$ (but that, unlike PUM, exhibits high nontarget-based resistance, presumably at the level of uptake or efflux, precluding development as an antibacterial drug).

The structure enables structure-based design of novel PUM analogs with increased potency and increased selectivity. Initial lead-optimization efforts corroborate the importance of the PUM N-hydroxy, glutamine, and guanidinyl moieties and demonstrate that the PUM glutamine $\mathrm{C}(\mathrm{O}) \mathrm{NH}_{2}$ can be replaced by $\mathrm{C}(\mathrm{O})$ NHR while retaining RNAP inhibitory and antibacterial activity (Extended Data Fig. 7).

Our results provide a new class of antibiotic with activity against Gram-positive and Gram-negative bacteria in vitro and in vivo, no cross-resistance with current antibacterial drugs, and low rates of resistance emergence. Our discovery of a new class of antibiotic from conventional microbial extract screening indicates that, contrary to widespread belief ${ }^{1}$, conventional microbial extract screening has not been exhausted as a source of new antibacterial lead compounds.

Our results provide the first example of a selective NAI of bacterial RNAP. NAIs of viral nucleotide polymerases have been of immense importance for development of anti-HIV ${ }^{3}$ and anti-HCV drugs. NAIs of bacterial RNAP may show comparable promise for development of antibacterial drugs. 


\section{References}

1. Marston, H., Dixon, D., Knisely, J., Palmore, T. \& Fauci, A. Antimicrobial resistance. JAMA 316, 1193-1204 (2016).

2. Brown, E. \& Wright, G. Antibacterial drug discovery in the resistance era. Nature 529, 336-343 (2016).

3. Cihlar, T. \& Ray, A. Nucleoside and nucleotide HIV reverse transcriptase inhibitors: 25 years after zidovudine. Antiviral Res. 85, 39-58 (2010).

4. Summers, B., Beavers, J. \& Klibanov, O. Sofosbuvir [Solvadi], a novel nucleotide analogue inhibitor used for the treatment of hepatitis C virus. J. Pharm. Pharmacol. 66, 1653-1666 (2014).

5. Zhang, Y., Degen, D., Ho, M., Sineva, E., Ebright, K., Ebright, Y., Mekler, V., VahedianMovahed, H., Feng, Y., Yin, R., Tuske, S., Irschik, H., Jansen, R., Maffioli, S., Donadio, S., Arnold, E. \& Ebright, R.H. GE23077 binds to the RNA polymerase 'i' and 'i+1' sites and prevents the binding of initiating nucleotides. eLife 3, e02450 (2014).

6. Landwehr, W., Wolf, C. \& Wink, J. Actinobacteria and Myxobacteria: two of the most important bacterial resources for novel antibiotics. Curr. Top. Microbiol. Immunol. 398, 273-302 (2016).

7. Jin, D. J. \& Gross, C. Mapping and sequencing of mutations in the Escherichia coli rpoB gene that lead to rifampicin resistance. J. Mol. Biol. 202, 45-58 (1988).

8. Garibyan, L., Huang, T., Kim, M., Wolff, E., Nguyen, A., Nguyen, T., Diep, A., Hu, K., Iverson, A., Yang, H. \& Miller, J. Use of the $r p o B$ gene to determine the specificity of base substitution mutations on the Escherichia coli chromosome, DNA Repair 2, 593-608 (2003).

9. Campbell, E., Korzheva, N., Mustaev, A., Murakami, K., Nair, S., Goldfarb, A. \& Darst, S. Structural mechanism for rifampicin inhibition of bacterial RNA polymerase. Cell 104, 901-912 (2001).

10. Ebright, R. RNA exit channel--target and method for inhibition of bacterial RNA polymerase. WO/2005/001034 (2005). 
11. Srivastava, A., Talaue, M., Liu, S., Degen, D., Ebright, R.Y., Sineva, E., Chakraborty, A., Druzhinin, S., Chatterjee, S., Mukhopadhyay, J., Ebright, Y.., Zozula, A., Shen, J., Sengupta, S., Niedfeldt, R., Xin, C., Kaneko, T., Irschik, H., Jansen, R., Donadio, S., Connell, N. \& Ebright, R.H. New target for inhibition of bacterial RNA polymerase: "switch region". Curr. Opin. Microbiol. 14, 532-543 (2011).

12. Mukhopadhyay, J., Das, K., Ismail, S., Koppstein, D., Jang, M., Hudson, B., Sarafianos, S., Tuske, S., Patel, J., Jansen, R., Irschik, H., Arnold, E. \& Ebright, R.H. The RNA polymerase "switch region" is a target for inhibitors. Cell 135, 295-307 (2008).

13. Belogurov, G., Vassylyeva, M., Sevostyanova, A., Appleman, J., Xiang, A., Lira, R., Webber, S., Klyuyev, S., Nudler, E., Artsimovitch, I. \& Vassylyev, D. Transcription inactivation through local refolding of the RNA polymerase structure. Nature 45, 332-335. (2009).

14. Tuske, S., Sarafianos, S., Wang, X., Hudson, B., Sineva, E., Mukhopadhyay, J., Birktoft, J., Leroy, O., Ismail, S., Clark, A., Dharia, C., Napoli, A., Laptenko, O., Lee, J., Borukhov, S., Ebright, R.H. \& Arnold, E. Inhibition of bacterial RNA polymerase by streptolydigin: stabilization of a straight-bridge-helix active-center conformation. Cell 122, 541-552 (2005).

15. Temiakov, D., Zenkin, N., Vassylyeva, M., Perederina, A., Tahirov, T., Kaihatsu, K., Savkina, M., Zorov, S., Nikiforov, V., Igarashi, N., Matsugaki, N., Wakatsuki, S., Severinov, K. \& Vassylyev, D. Structural basis of transcription inhibition by antibiotic streptolydigin. Mol. Cell 19, 655-666 (2005).

16. Feng, Y., Degen, D., Wang, X., Gigliotti, M., Liu, S., Zhang, Y., Das, D., Michalchuk, T., Ebright, Y., Talaue, M., Connell, N. \& Ebright, R.H. Structural basis of transcription inhibition by CBR hydroxamidines and CBR pyrazoles. Structure 23, 1470-1481 (2015).

17. Bae, B., Nayak, D., Ray, A., Mustaev, A., Landick, R. \& Darst, S. CBR antimicrobials inhibit RNA polymerase via at least two bridge-helix cap-mediated effects on nucleotide addition. Proc. Natl. Acad. Sci. USA 112, E4178-E4187 (2015). 
18. Degen, D., Feng, Y., Zhang, Y., Ebright, K., Ebright, Y., Gigliotti, M., Vahedian-Movahed, H., Mandal, S., Talaue, M., Connell, N., Arnold, E., Fenical, W. \& Ebright, R.H. Transcription inhibition by the depsipeptide antibiotic salinamide A. eLife 3, e02451 (2014).

21. Sagitov, V., Nikiforov, V. \& Goldfarb, A. Dominant lethal mutations near the 5 ' substrate binding site affect RNA polymerase propagation. J. Biol. Chem. 268, 2195-2202. (1993).

22. Svetlov, V., Vassylyev, D. \& Artsimovitch, I. Discrimination against deoxyribonucleotide substrates by bacterial RNA polymerase. J. Biol. Chem. 279, 38087-38090 (2004).

21. Sosunov, V., Zorov, S., Sosunova, E., Nikolaev, A., Zakeyeva, I., Bass, I., Goldfarb, A., Nikiforov, V., Severinov, K. \& Mustaev, A. The involvement of the aspartate triad of the active center in all catalytic activities of multisubunit RNA polymerase. Nucl. Acids Res. 33, 4202-4211 (2005).

22. Jovanovic, M., Burrows, P., Bose, D., Cámara, B., Wiesler, S., Weinzierl, R., Zhang, X., Wigneshweraraj, S. \& Buck, M. An activity map of the Escherichia coli RNA polymerase bridge helix. J. Biol. Chem. 286, 14469-14479 (2011).

23. Yuzenkova, Y., Roghanian, M. \& Zenkin, N. Multiple active centers of multi-subunit RNA polymerases. Transcription 3, 115-118 (2012). 


\section{Acknowledgements}

Work was supported by NIH grants GM041376 and AI104660 to RHE and Italian Ministry of Research and Regione Lombardia grants to NAICONS. We thank former colleagues at Vicuron Pharmaceuticals for early characterization of PUM, S. Parapini for cytotoxicity assays, W. Fenical for Sal, A. Berk and I. Grummt for plasmids, NARSA and BEI Resources for strains, and the Cornell High Energy Synchrotron Source for beamline access.

\section{Data Availability}

Atomic coordinates and structure factors for reported crystal structures have been deposited with the Protein Data Bank under accession codes 5X21 (RPo-GpA-PUM) and 5X22 (RPo-GpA-CMPcPP).

\section{Author Contributions}

S.M. performed structure elucidation of PUM and semi-syntheses and syntheses of PUM derivatives. Y.Z. purified RNAP, assessed template-specificity of inhibition and determined crystal structures. D.D. purified RNAP, and assessed RNAP-inhibitory activities, antibacterial activities, resistance, and cross-resistance. T.C., S.S., and G.D. assessed RNAP-inhibitory activities. G.D.G. and C.M. purified PUM and participated in semi-syntheses and syntheses of PUM derivatives. P.M. performed characterization and fermentation of the PUM producer strain. P.G. and G.C. performed mouse infection studies. A.I.C. and H.-G.S. performed macromolecular synthesis assays. G.F. and P.K. performed microbial extract screening and dereplication. S.D. and R.H.E. designed the study, analyzed data, and wrote the paper.

\section{Author Information}

S.M., S.S, P.M., and S.D. are employees and/or shareholders of NAICONS. Y.Z., S.M., S.S., P.M., P.G., G.C., S.D., and R.H.E. have patent filings. The other authors declare that no competing interests exist. (Vicuron Pharmaceuticals no longer is operational.) Correspondence and requests for materials should be addressed to S.D. (시onadio@naicons.com) or R.H.E. (ebright@waksman.rutgers.edu). 
Figure Legends

Figure 1. Structure, RNAP-inhibitory activity, and antibacterial activity of PUM.

a, Structure of PUM. b, RNAP-inhibitory activity of PUM. c, Antibacterial activity of PUM in vitro. d, Antibacterial activity of PUM in vivo. Drug resistances are as follows: Ami. amikacin; Azi, azithromycin; Cip, ciprofloxacin; Ctr, ceftriaxone; Dap, daptomycin; Ery, erythromycin; Chl, chloramphenicol; Cli, clindamycin; Gen, gentamycin; Lin, linezolid; Met, methicillin; Mup, mupirocin; Pen, penicillin; Ox, oxacillin; Rif, rifampin; Tec, teicoplanin; Tet, tetracycline; Tri, trimethoprim; Van, vancomycin. e, Absence of cross-resistance between PUM and Rif (data for S. pyogenes Rif-resistant mutants; residues numbered as in S. pyogenes and, in parentheses, E. coli). f, Additive antibacterial activity of PUM and Rif.

\section{Figure 2. Target of PUM: RNAP i+1 NTP binding site.}

a, Spontaneous resistance rates for PUM and Rif. b, S. pyogenes spontaneous PUM-resistant mutants. c, Location of PUM target (blue) in three-dimensional structure of bacterial RNAP ${ }^{12}$ (gray; black circle for active-center region; violet sphere for active-center $\mathrm{Mg}^{2+}(\mathrm{I}) ; \beta^{\prime}$ non-conserved region and $\sigma$ omitted for clarity). d, Absence of overlap between PUM target (blue) and Rif (red), Lpm (cyan), Myx (pink), and Stl (yellow) targets. e, Absence of high-level cross-resistance for S. pyogenes PUM-resistant mutants to Rif, Lpm, Myx, and Stl.

Figure 3. Mechanism of PUM: competition with UTP for occupancy of RNAP i+1 NTP binding site. a, Suppression of inhibition by PUM by high [UTP], but not high [GTP], [ATP], or [CTP]. b, Inhibition by PUM of transcription directing incorporation of $\mathrm{U}+\mathrm{G}+\mathrm{A}+\mathrm{C}$, but not "U-less" transcription specifying incorporation of G+A+C. c, Single-nucleotide-addition reactions showing that inhibition by PUM requires template positions directing incorporation of $U$ (row 1) and prefers preceding template positions directing incorporation of G, A, or $\mathrm{U}$ (columns 1-3). d, Multiple-nucleotide-addition reactions showing 
that inhibition by PUM requires template positions directing incorporation of $U$ (red GU, AU, or UU, and pink $\mathrm{CU}$ ) and prefers preceding template positions directing incorporation of $\mathrm{G}, \mathrm{A}$, or $\mathrm{U}$ (red GU, AU, or UU).

\section{Figure 4. Structural basis of transcription inhibition by PUM}

Structures of transcription initiation complexes containing PUM (a) and CMPcPP (b). Top, crystallization and refinement statistics (left) and experimental electron density and fit (right). Green, PUM; pink, RNA and CMPcPP; red, DNA template strand; violet sphere between $\mathrm{i}$ and $\mathrm{i}+1$ sites, $\mathrm{Mg}^{2+}(\mathrm{I})$; violet sphere in $\mathrm{i}+1$ site, $\mathrm{Mg}^{2+}(\mathrm{II})$; gray; RNAP bridge helix; green mesh, $\mathrm{mF}_{\mathrm{o}}-\mathrm{DF}_{\mathrm{c}}$ omit map (contoured at $2.5 \sigma$ ). Middle, stereodiagram of interactions. Green, PUM carbon atoms; pink, RNA and CMPcPP carbon atoms; gray, RNAP carbon atoms; red, blue, yellow, and orange, oxygen, nitrogen, sulfur, and phosphorous atoms; dashed lines, H-bonds; other colors, as above. Bottom, summary of interactions. Red dashed lines, H-bonds; blue arcs, van der Waals interactions. Residues numbered as in T. thermophilus RNAP and, in parentheses, E. coli RNAP. 
bioRxiv preprint doi: https://doi.org/10.1101/106906; this version posted February 8, 2017. The copyright holder for this preprint (which was not certified by peer review) is the author/funder. All rights reserved. No reuse allowed without permission.

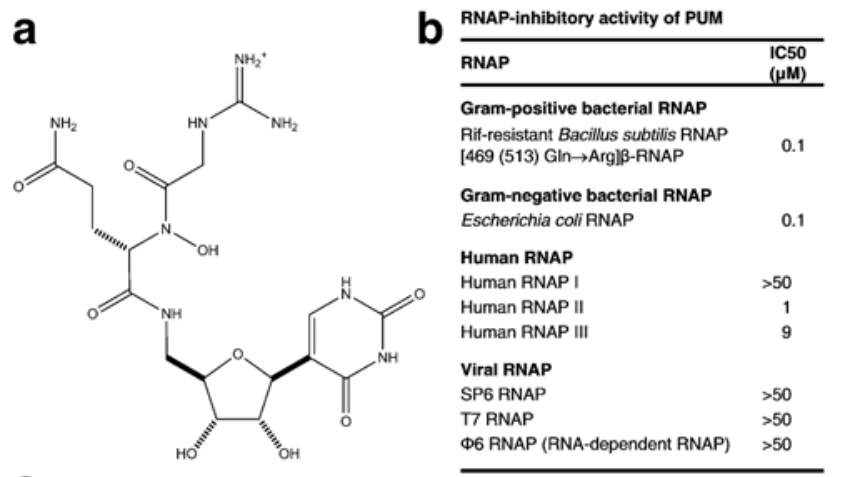

C

antibacterial activity of PUM in vitro

\begin{tabular}{lc}
\hline organism & $\begin{array}{c}\text { IC50 } \\
(\boldsymbol{M M})\end{array}$ \\
\hline Gram-positive bacteria & 4 \\
Streptococcus pyogenes L49 & 4 \\
Streptococcus pyogenes L49 in the presence of 30\% human serum & 4 \\
Streptococcus pneumoniae L44 & 4 \\
Streptococcus pneumoniae L44 in the presence of 30\% human serum & 6 \\
Streptococcus pneumoniae L899 (Rif-resistant) & 6 \\
Streptococcus pneumoniae L1407 (Azi-resistant) & 6 \\
Streptococcus pneumoniae ND061311 (Pen-Azi-resistant) & 4 \\
Streptococcus pneumoniae L3909 (Pen-Ery-Chl-Ctr-resistant) & 6 \\
Streptococcus pneumoniae L1542 (Ery-Cli-Ami-Gen-Tet-resistant) & 6 \\
Streptococcus pneumoniae L2868 (Met-Oxa-Ery-Cli-Ami-Gen-Tet-Tri-Chl-resistant) & 8 \\
Staphyiococcus aureus ATCC 12600 & 8 \\
Staphylococcus aureus ATCC 12600-S531L (Rif-resistant) & 4 \\
Staphylococcus aureus BAA-1707 (Met-resistant) & 8 \\
Staphylococcus aureus CB1616 (Met-Dap-resistant) & 16 \\
Staphylococcus aureus NRS120 (Met-Cip-Gen-Tet-Tri-Lin-resistant) & 16 \\
Staphylococcus aureus NRS1 (Rif-Met-Cip-Ery-Cli-Gen-Tet-Dap-resistant; Van-intermediate) & 8 \\
Staphylococcus aureus VRS1 (Rif-Met-Cip-Ery-Cli-Gen-Mup-Tec-Van-resistant) & 4 \\
Enterococcus faecium ATCC 19434 & \\
Gram-negative bacteria & 2 \\
Haemophilus influenzae L3296 & 2 \\
Moraxella catarmhalis L3294 & 2 \\
Human cells & $>100$ \\
Human macrovascular endothelial & $>100$ \\
Human monocyte &
\end{tabular}

d

antibacterial activity of PUM in vivo: mouse Streptococcus pyogenes peritonitis model \begin{tabular}{ll}
\hline organism & ED50 (total dose; $\mathrm{mg} / \mathrm{kg}$ ) \\
( $95 \%$ confidence interval)
\end{tabular}

intravenous (iv) administration, $10 \mathrm{~min}$ and $6 \mathrm{~h}$ post-infection $9(5-20)$

intravenous (iv) administration, 10 min post-infection $\quad 20(3-100)$

\begin{tabular}{ll} 
Intravenous (iv) administration, 10 min post-infection & $20(3-100)$ \\
subcutaneous (sc) administration, 10 min post-infection & $30(20-40)$ \\
\hline
\end{tabular}

sereng

e

absence of cross-resistance between PUM and Rif

\begin{tabular}{|c|c|c|}
\hline \multirow[t]{2}{*}{ amino acid substitution } & \multicolumn{2}{|c|}{ 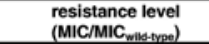 } \\
\hline & Rif & PUM \\
\hline \multicolumn{3}{|l|}{$r p o B$ (RNAP $\beta$ subunit) } \\
\hline 135 (146) Val $\rightarrow$ Phe & $>2048$ & 1 \\
\hline 472 (512) Ser $\rightarrow$ Pro & 64 & 1 \\
\hline $473(513)$ Gln $\rightarrow$ Arg & $>2048$ & 1 \\
\hline 473 (513) Gln $\rightarrow$ Lys & $>2048$ & 1 \\
\hline 476 (516) Asp $\rightarrow$ Asn & 32 & 1 \\
\hline 476 (516) Asp $\rightarrow$ Tyr & 256 & 1 \\
\hline 476 (516) Asp $\rightarrow$ Val & $>2048$ & 1 \\
\hline 482 (522) Ser $\rightarrow$ Leu & $>2048$ & 1 \\
\hline 486 (526) His $\rightarrow$ Tyr & $>2048$ & 1 \\
\hline 491 (531) Ser $\rightarrow$ Phe & $>2048$ & 1 \\
\hline 491 (531) Ser $\rightarrow$ Tyr & $>2048$ & 1 \\
\hline 494 (534) Gly $\rightarrow$ Val & 128 & 0.5 \\
\hline 524 (564) Pro $\rightarrow$ Leu & 512 & 4 \\
\hline
\end{tabular}

f

additive antibacterial activity of PUM and Rif

\begin{tabular}{lccc}
\hline organism & FICl $_{\min }$ & FICl $_{\max }$ & interaction type \\
\hline Streptococcus pyogenes L49 & 1.0 & 1.5 & additive \\
Streptococcus pneumoniae L44 & 1.0 & 1.6 & additive \\
\hline
\end{tabular}

Figure 1 
bioRxiv preprint doi: https://doi.org/10.1101/106906; this version posted February 8, 2017. The copyright holder for this preprint (which was not certified by peer review) is the author/funder. All rights reserved. No reuse allowed without permission.

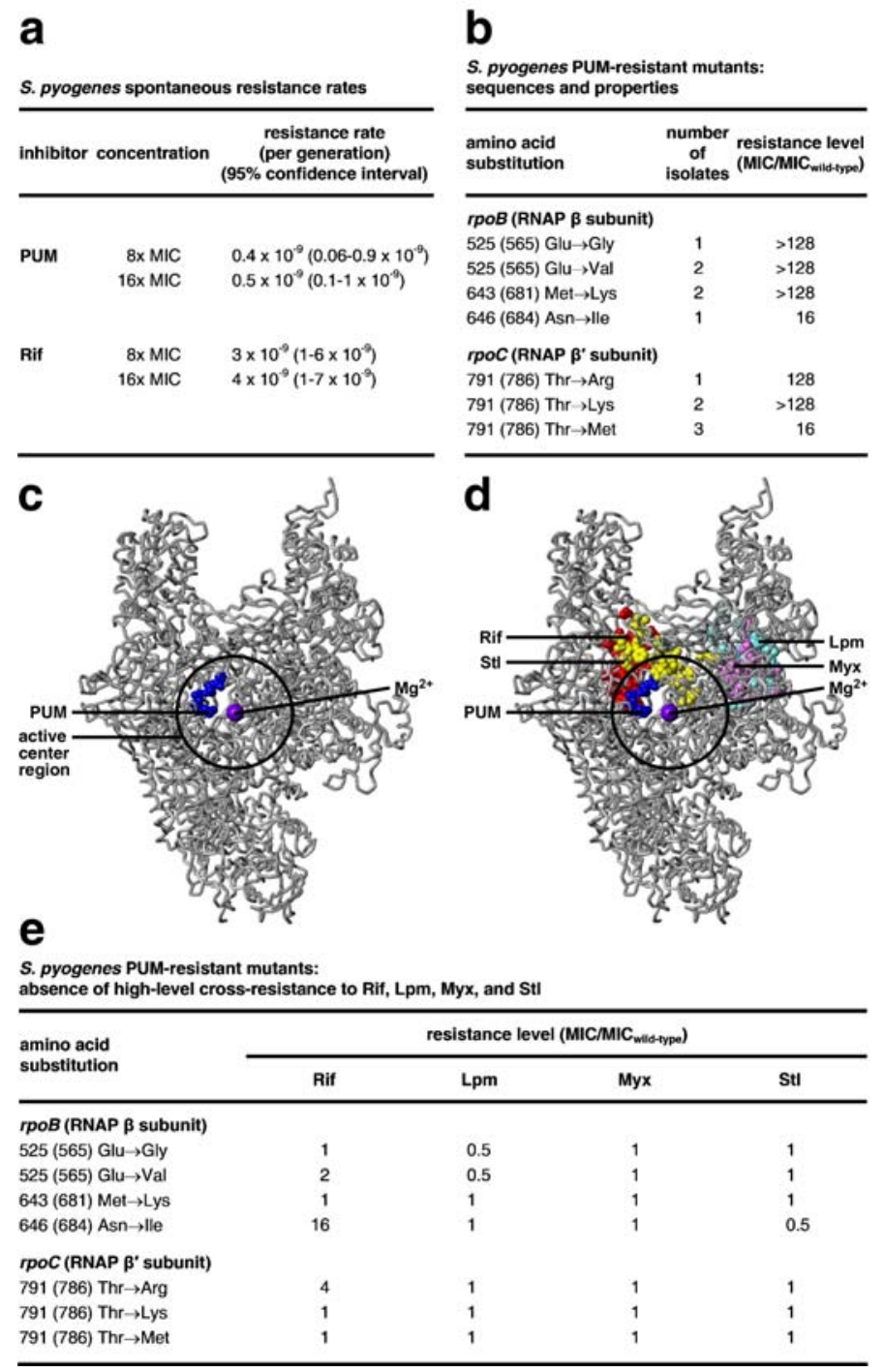

\section{Figure 2}



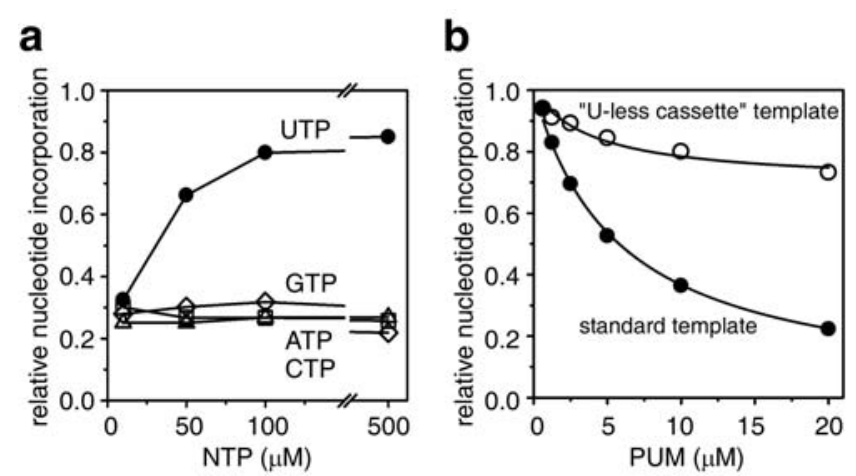

\section{d}

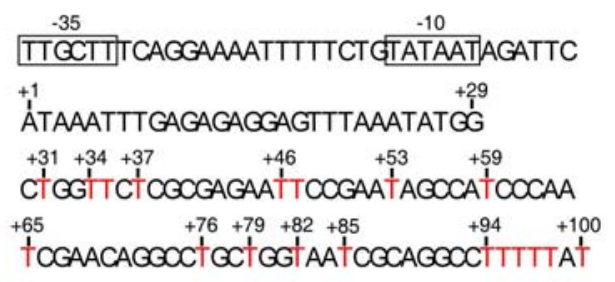

C

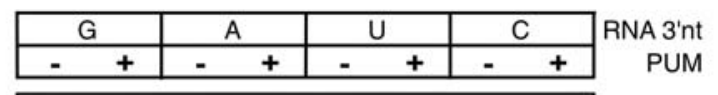

UTP

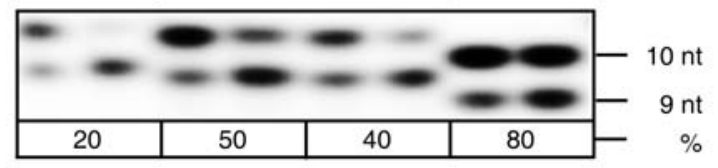

GTP
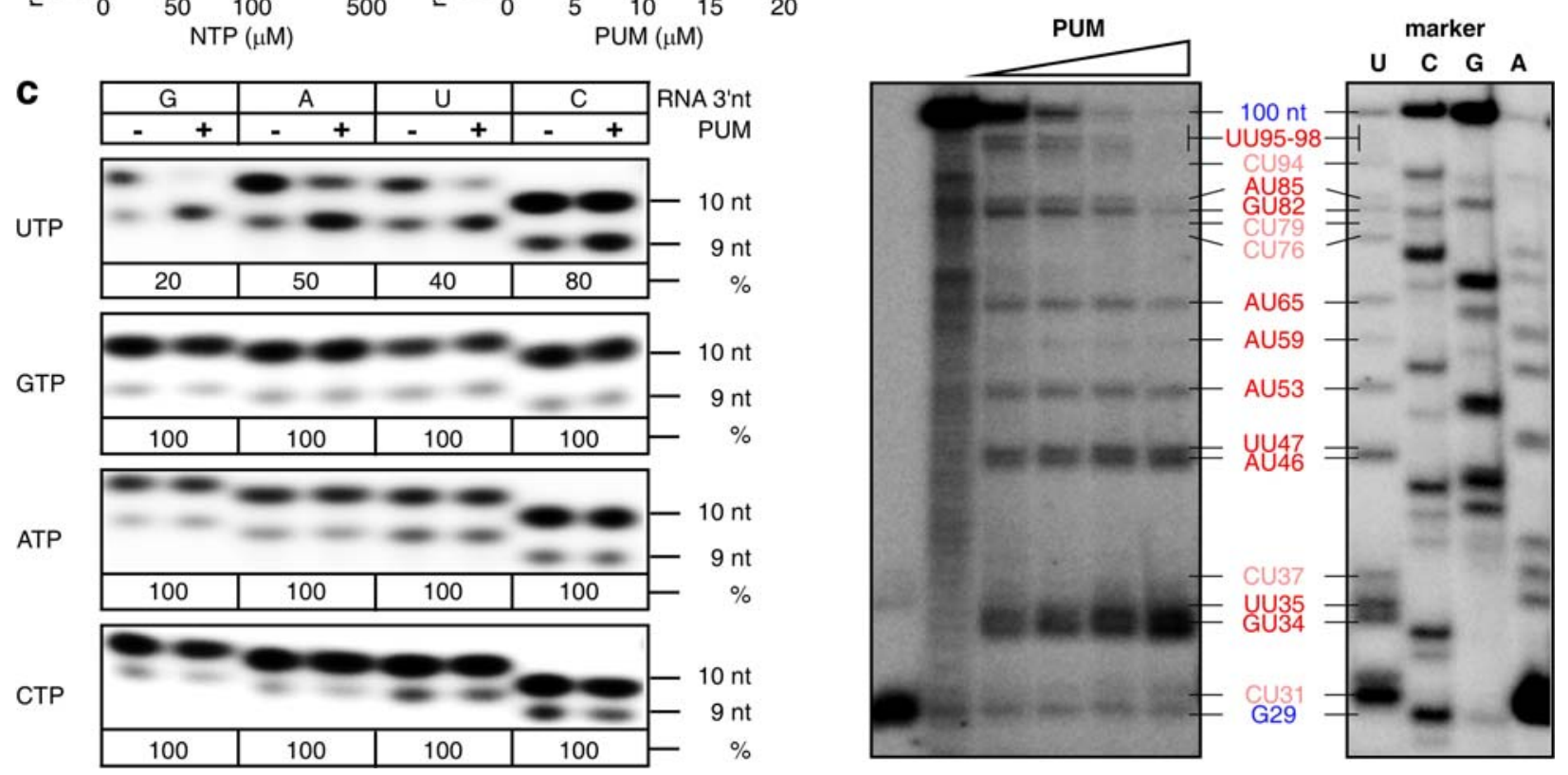

Figure 3 
a

\begin{tabular}{|c|c|}
\hline $\begin{array}{l}\text { dataset } \\
\text { beamline } \\
\text { space group } \\
\text { resolution range }(A) \\
\text { cell parameters }(A)\end{array}$ & $\begin{array}{l}\text { RPo-GpA-PUM } \\
\text { CHESS-F1 } \\
\text { C2 } \\
40.00-3.30(3.36-3.30) \\
a=186.8, b=103.1, c=296.2 \\
a=90.0^{\circ}, B=98.7^{\circ}, \quad=90.0^{\circ}\end{array}$ \\
\hline completeness (\%) & $\begin{array}{l}\alpha=90.0^{\circ}, \beta=98.7^{\prime}, \gamma=90 \\
0.920(0.874)\end{array}$ \\
\hline redundancy & $\begin{array}{l}3.4(3.4) \\
3.814)\end{array}$ \\
\hline mean $\mathrm{V} / \sigma$ & $8.4(1.7)$ \\
\hline Rimergo & $0.138(0.633)$ \\
\hline Rwork/Riree & $0.232 / 0.280$ \\
\hline B factor $\left(\bar{A}^{2}\right)$ & 61.6 \\
\hline bond-length RMSD ( $(\bar{A})$ & 0.002 \\
\hline bond-angle RMSD $\left({ }^{\circ}\right)$ & 0.542 \\
\hline PDB code & $5 \times 21$ \\
\hline
\end{tabular}
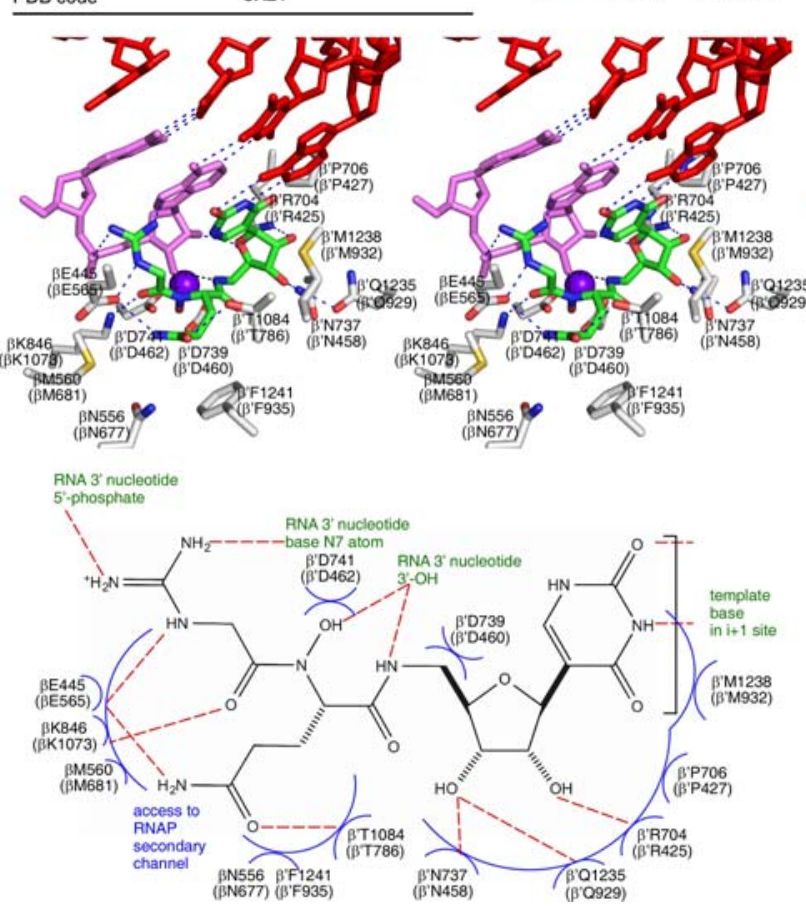

b

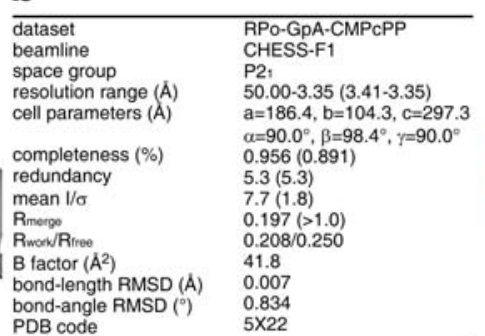
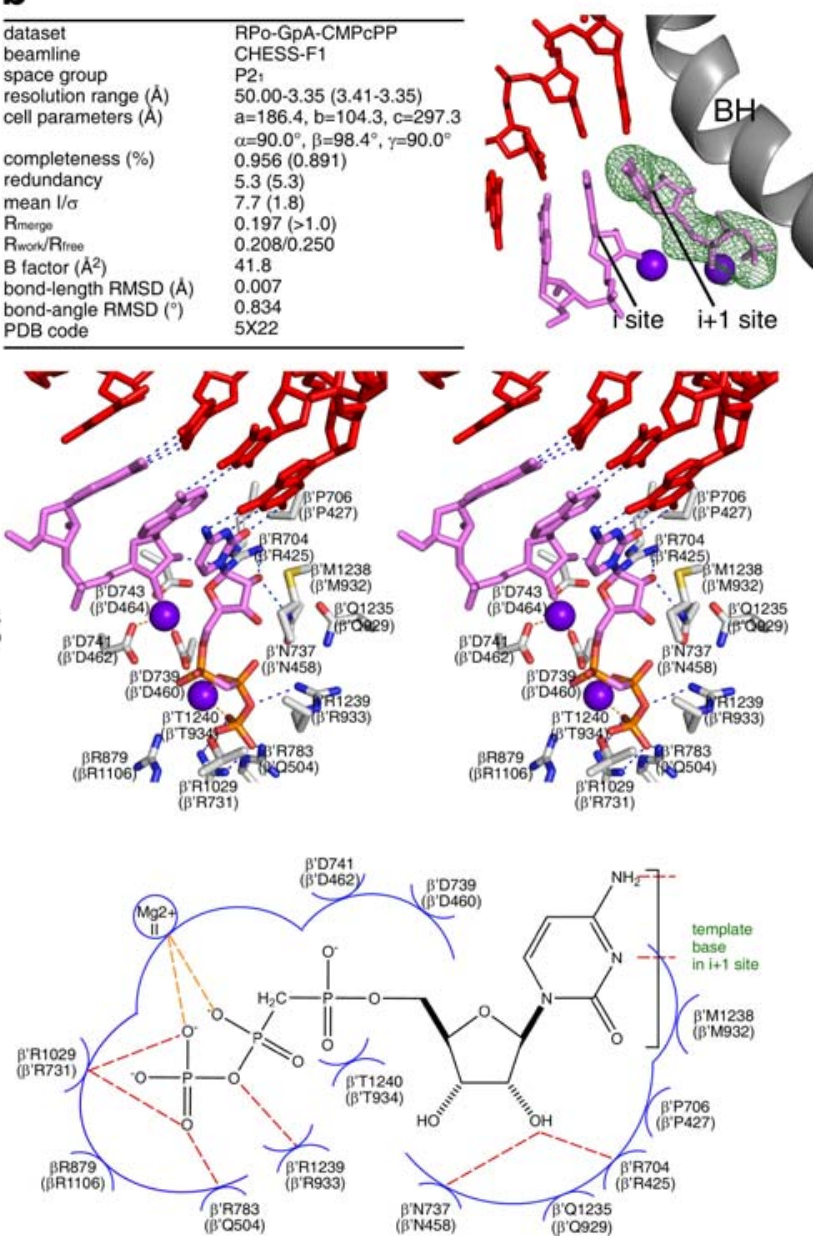

\section{Figure 4}




\section{METHODS}

\section{E. coli RNAP core enzyme}

For experiments in Fig. 3c, E. coli RNAP core enzyme was prepared from E. coli strain BL21(DE3) (Invitrogen) transformed with plasmids $\mathrm{pEcABC}-\mathrm{H} 6^{24}$ and $\mathrm{pCDF} \omega^{25}$, using procedures as described $^{26}$

For experiments assessing promoter-independent transcription in Extended Data Table 1, E. coli RNAP core enzyme was prepared from E. coli strain XE $54^{27}$ transformed with plasmid pRL $706^{28}$, using procedures as described ${ }^{29}$.

\section{E. coli RNAP $\sigma^{70}$ holoenzyme}

For experiments in Fig. 3d, E. coli RNAP $\sigma^{70}$ holoenzyme was prepared from E. coli strain $\mathrm{XE} 54^{26}$ transformed with plasmid pREII-NH $\alpha^{29}$, using procedures as described ${ }^{18}$.

For experiments in Extended Data Fig. $4 c$, E. coli RNAP $\sigma^{70}$ holoenzyme and $[565 \mathrm{Glu} \rightarrow \mathrm{Asp}] \beta$-RNAP $\sigma^{70}$ holoenzyme were prepared from $E$. coli strain XE54 ${ }^{26}$ transformed with plasmid pRL $706^{28}$ or pRL706-565D ${ }^{5}$, using procedures as described ${ }^{29}$.

\section{B. subtilis RNAP $\sigma^{\mathrm{A}}$ holoenzyme}

Rif-resistant $B$. subtilis [469 (513) Gln $\rightarrow$ Arg] $\beta$-RNAP $\sigma^{A}$ holoenzyme was prepared from $B$. subtilis strain MH5636-Q469R (spontaneous Rif-resistant mutant of B. subtilis strain MH5636 ${ }^{30}$; selected on LB agar containing $2 \mu \mathrm{g} / \mathrm{ml}$ Rif; confirmed by PCR amplification and sequencing of $r p o B$ ) using procedures essentially as described ${ }^{30}$.

\section{T. thermophilus RNAP $\sigma^{\mathrm{A}}$ holoenzyme}

T. thermophilus RNAP $\sigma^{\mathrm{A}}$ holoenzyme was prepared as described ${ }^{5}$.

\section{Microbial extract screening}

A sub-library of $\sim 3,000$ microbial extracts (prepared as described ${ }^{31}$ ) with growth-inhibitory activity against Staphylococcus aureus ATCC 6538 was screened for the ability to inhibit E. coli RNAP and bacteriophage SP6 RNAP (Promega). Screening was performed using 96-well microplates. Reactions contained ( $50 \mu \mathrm{l}$ ): $5 \mu \mathrm{l}$ extract (dissolved in 10\% DMSO), $0.2 \mathrm{U}$ E. coli RNAP $\sigma^{70}$ holoenzyme (SigmaAldrich) or 0.2 U SP6 RNAP (Promega), $0.2 \mathrm{nM}$ plasmid pUC18 (Clontech; for assays with E. coli RNAP) or $0.2 \mathrm{nM}$ plasmid pGEM-3Z (Promega; for assays with SP6 RNAP), $500 \mu \mathrm{M}$ ATP, $500 \mu \mathrm{M}$ GTP, $500 \mu \mathrm{M}$ CTP, and $2 \mu \mathrm{M}$ [ $\left.\alpha^{32} \mathrm{P}\right] \mathrm{UTP}$ (0.2 Bq/fmol; PerkinElmer), in $20 \mathrm{mM}$ Tris-acetate (pH 7.9), 50 $\mathrm{mM} \mathrm{KCl}, 4 \mathrm{mM}$ magnesium acetate, $0.1 \mathrm{mM}$ EDTA, $5 \mathrm{mM}$ dithiothreitol, and $100 \mu \mathrm{g} / \mathrm{ml}$ bovine serum albumin. Reaction components except DNA were pre-equilibrated $10 \mathrm{~min}$ at $22^{\circ} \mathrm{C}$. Reactions were initiated by addition of DNA, were allowed to proceed $1 \mathrm{~h}$ at $22^{\circ} \mathrm{C}$, and were terminated by addition of $150 \mu \mathrm{l}$ ice-cold $10 \%(\mathrm{w} / \mathrm{v})$ trichloroacetic acid (TCA). After $1 \mathrm{~h}$ at $4^{\circ} \mathrm{C}$, resulting TCA precipitates were collected on glass-fiber filters (UniFilter GF/B; PerkinElmer) using a 96-well harvester (Packard) and were washed once with water. Radioactivity was quantified using a TopCount scintillation counter (Packard), and \% inhibition was calculated as:

$\%$ inhibition $=100-\left[100\left(\mathrm{R}_{\text {sample }}-\mathrm{R}_{\text {neg }}\right) /\left(\mathrm{R}_{\text {pos }}-\mathrm{R}_{\text {neg }}\right)\right]$

where $\mathrm{R}_{\text {sample }}, \mathrm{R}_{\mathrm{pos}}$ and $\mathrm{R}_{\text {neg }}$ are observed radioactivity levels in a reaction, in a control reaction without extract, and in a control reaction without plasmid, respectively.

Two extracts that inhibited the reaction with E. coli RNAP by $\geq 80 \%$, that did not inhibit the reaction with SP6 RNAP, and that did not contain mass-spectrometry signals indicative of a previously characterized RNAP inhibitor, were designated as "hit extracts." 


\section{Characterization of producer strains}

The producer strains of the hit extracts were strains IDI38640 and IDI38673. ID38640 and ID38673 are Actinobacterial isolates from soil samples collected in Italy and France, respectively. ID38640 and ID38673 exhibit cell morphologies consistent with the genus Streptomyces and exhibit 16S rRNA gene sequences (determined as described ${ }^{32}$; GenBank accession numbers JQ929050 and JQ929051) that were $99.9 \%$ identical over $1.4 \mathrm{kB}$ to each other and were highly similar to those of a cluster of closely-related Streptomyces species (S. nigrescens, S. tubercidicus, S. rimosus subsp. rimosus, S. hygroscopicus subsp. angustmyceticus, and S. libani subsp. libani).

\section{Isolation and purification of PUM}

For each producer strain of a hit extract, the strain was cultured on a $55 \mathrm{~mm}$ BTT agar plate ${ }^{31} 4-7$ days at $30^{\circ} \mathrm{C}$, the mycelium was scraped from the plate and used to inoculate a $50 \mathrm{ml}$ Erlenmeyer flask containing $15 \mathrm{ml}$ of seed medium $(20 \mathrm{~g} / \mathrm{L}$ dextrose monohydrate, $2 \mathrm{~g} / \mathrm{L}$ yeast extract, $8 \mathrm{~g} / \mathrm{L}$ soybean meal, $1 \mathrm{~g} / \mathrm{L} \mathrm{NaCl}$, and $4 \mathrm{~g} / \mathrm{L} \mathrm{CaCO}_{3}, \mathrm{pH} 7.3$ ), and the resulting culture was incubated $48 \mathrm{~h}$ at $30^{\circ} \mathrm{C}$ on a rotary shaker (200 rpm agitation) for $48 \mathrm{~h}$. Following initial incubation, $5 \mathrm{ml}$ of the culture was used to inoculate $100 \mathrm{ml}$ of fresh seed medium in a 500-ml flask, and the resulting culture was incubated $72 \mathrm{~h}$ under the same conditions. A $5 \%(\mathrm{v} / \mathrm{v})$ inoculum was transferred into $2 \mathrm{~L}$ of production medium $(10 \mathrm{~g} / \mathrm{L}$ dextrose monohydrate, $24 \mathrm{~g} / \mathrm{L}$ maize dextrin, $8 \mathrm{~g} / \mathrm{L}$ soy peptone, $5 \mathrm{~g} / \mathrm{L}$ yeast extract, and $1 \mathrm{~g} / \mathrm{L} \mathrm{NaCl}, \mathrm{pH} 7.2)$ in a 3 -L vessel, and the resulting culture was grown in a BioFlo 115 Fermentor (Eppendorf) $96 \mathrm{~h}$ at $30^{\circ} \mathrm{C}$, with aeration at 0.5 volume air per volume medium per min stirring at $600 \mathrm{rpm}$. The culture was filtered through 10.25 in disc filter paper (Scienceware), and the resulting cleared broth was concentrated to $\sim 1 \mathrm{~L}$ in vacuo and loaded onto a column of $500 \mathrm{mg}$ of Dowex $50 \mathrm{~W}$ x 400 mesh (previously activated with two bed volumes of $5 \% \mathrm{HCl}$ and washed with $\mathrm{H}_{2} \mathrm{O}$ until neutralization). After washing with 5 bed volumes each of $20 \mathrm{mM}$ sodium acetate at $\mathrm{pH} 6$ and sodium acetate at $\mathrm{pH} 7$, PUM was eluted using six bed volumes of $100 \mathrm{mM} \mathrm{NH}_{4} \mathrm{OAc}$ at $\mathrm{pH}$ 9. PUM-containing fractions were desalted by reversed-phase medium-pressure liquid chromatography on Combiflash Rf (Teledyne Isco) using a $30 \mathrm{~g} \mathrm{C18} \mathrm{RediSep} \mathrm{Rf}$ column (Teledyne Isco) with linear gradient from 0 to $20 \%$ phase B in 20 min (phase A, $0.02 \%$ trifluoroacetic acid in $\mathrm{H}_{2} \mathrm{O}$; phase $\mathrm{B}$, acetonitrile) and flow rate of $35 \mathrm{ml} / \mathrm{min}$. PUM-containing fractions were pooled, concentrated, and lyophilized twice to yield $196 \mathrm{mg}$ of a white solid highly soluble in water, DMSO, and methanol.

\section{Structure elucidation of PUM}

Ion-trap ESI-MS (Bruker Esquire 3000 Plus showed a protonated molecular ion at $\mathrm{m} / \mathrm{z} 487$ $[\mathrm{M}+\mathrm{H}]^{+}$and a bimolecular ion at $973[2 \mathrm{M}+\mathrm{H}]^{+}$Extended Data Fig. 1). Ion-trap ESI--MS/MS (Bruker Esquire 3000 Plus ) showed major peaks at $\mathrm{m} / \mathrm{z} 334,353,371,389,452$, and $479[\mathrm{M}+\mathrm{H}]^{+}$. HR-MS (Thermo Fisher Exactive) showed an exact mass of 487.18865 , consistent with the molecular formula $\mathrm{C}_{17} \mathrm{H}_{26} \mathrm{~N}_{8} \mathrm{O}_{9}$.

Reversed-phase HPLC (Shimadzu Series 10 with SPD-M10A VP diode array detector; Waters Symmetry Shield RP8 $5 \mu \mathrm{m}, 250 \times 4.6 \mathrm{~mm}$, column; phase A $=2 \mathrm{mM}$ heptafluorobutyric acid in water; phase $\mathrm{B}=2 \mathrm{mM}$ heptafluorobutyric acid in acetonitrile; gradient $=0 \% \mathrm{~B}$ at $0 \mathrm{~min}, 10 \% \mathrm{~B}$ at $20 \mathrm{~min}, 95 \%$ $\mathrm{B}$ at $30 \mathrm{~min}$; flow rate $=1 \mathrm{ml} / \mathrm{min}$ ) showed a single peak with a retention time of 12 minutes. The UV-absorbance spectrum showed maxima at $200 \mathrm{~nm}$ and $262 \mathrm{~nm}$, consistent with the presence of a pyrimidine moiety ${ }^{33}$ (Extended Data Fig. 1).

The ${ }^{1} \mathrm{H}$ NMR spectrum $\left(600 \mathrm{MHz}\right.$ Bruker spectrometer in DMSO-d6 at $\left.25^{\circ} \mathrm{C}\right)$ revealed one

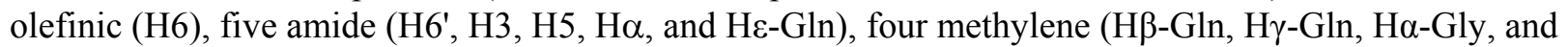
$\mathrm{H} 5^{\prime}$ ), and five methine (H1', H2', H3', H4', and $\mathrm{H} \alpha-\mathrm{Gln}$ ) signals (Extended Data Fig. 2a). The $2 \mathrm{D}{ }^{1} \mathrm{H}-{ }^{13} \mathrm{C}-$ HSQC and -HMBC NMR spectra (600 MHz Bruker spectrometer in DMSO-d6 at $\left.25^{\circ} \mathrm{C}\right)$ identified five carboxyl-amide groups $(\mathrm{C} 2, \mathrm{C} 4, \mathrm{C}=\mathrm{O} \mathrm{Gln}, \mathrm{C}=\mathrm{O}$ Gly, and $\mathrm{C} \delta$-Gln), two olefinic carbons $(\mathrm{C} 1$ and $\mathrm{C} 6)$, four methine carbons belonging to a sugar ring $\left(\mathrm{Cl}^{\prime}, \mathrm{C} 2{ }^{\prime}, \mathrm{C} 3^{\prime}\right.$, and $\left.\mathrm{C}^{\prime}\right)$, one other methine carbon $(\mathrm{C} \alpha-$ $\mathrm{Gln}$ ), and four methylene groups (C $\alpha-\mathrm{Gly}, \mathrm{C} \beta-\mathrm{Gln}, \mathrm{C} \gamma-\mathrm{Gln}$, and C5') (Extended Data Fig. 2b-c). 
The COSY NMR spectrum (600 MHz Bruker spectrometer in DMSO-d6 at $25^{\circ} \mathrm{C}$ ) identified correlations between the five sugar protons: $\mathrm{H} 1^{\prime}(\delta \mathrm{H} 4.35), \mathrm{H} 2^{\prime}(\delta \mathrm{H} 3.92), \mathrm{H} 3^{\prime}(\delta \mathrm{H} 3.65), \mathrm{H} 4{ }^{\prime}(\delta \mathrm{H} 3.65)$ and $\mathrm{H}^{\prime}$ ' ( $\left.\mathrm{\delta H}-\mathrm{A} 3.24 ; \mathrm{H}-\mathrm{B} 3.17\right)$. The chemical shift of $\mathrm{C}^{\prime}$ and ribose ${ }^{15} \mathrm{~N}-\mathrm{HSQC}$ correlations between $\mathrm{H}^{\prime}$ and $\mathrm{H} 5$ ' indicated the presence of 6 '-amino-ribose. Nitrogen signals N2 and N3 in the ${ }^{15} \mathrm{~N}$ HSQC spectrum, $\mathrm{HMBC}$ correlations of $\mathrm{H} 1$ ' to $\mathrm{C} 1, \mathrm{C} 2$ and $\mathrm{C} 6$, and $\mathrm{HMBC}$ correlations of $\mathrm{H} 6$ to $\mathrm{C} 1$ ', $\mathrm{C} 1, \mathrm{C} 2$, and $\mathrm{C} 6$, indicated the presence of uracil $\mathrm{C}$-linked to $\mathrm{C} 1$ ' of 6 '-amino-ribose. ${ }^{13} \mathrm{C}$-NMR spectra and COSY indicated the presence of a glutaminyl moiety, and HMBC correlations of H6' and the methine at $\delta_{\mathrm{H}} 4.72$ (H $\alpha$-Gln) to the carbonyl at $\delta_{\mathrm{c}} 169.5$ indicated linkage of the glutaminyl moiety to N6' of 6'-amino-ribose. $\mathrm{N} \varepsilon$ at $\delta 108.9$ was assigned by ${ }^{15} \mathrm{~N}$ HSQC. The absence of a glutaminyl $\mathrm{N} \alpha$ signal in the ${ }^{15} \mathrm{~N}$ HSQC spectrum suggested the possible presence of an hydroxamic acid, and this was confirmed by reduction of PUM with aqueous $\mathrm{TiCl}_{3}{ }^{34}$ to yield desoxy-PUM (1 in Extended Data Fig. 7a), exhibiting ion-trap ESIMS mass of $471[\mathrm{M}+\mathrm{H}]^{+}$, ion-trap ESI-MS/MS major peaks at $\mathrm{m} / \mathrm{z} 355$ and $372[\mathrm{M}+\mathrm{H}]^{+}$, and a new nitrogen peak at $\delta 117.7$ in the ${ }^{15} \mathrm{~N}$ HSQC spectrum assignable as glutaminyl $\mathrm{N \alpha}$, with corresponding $\mathrm{NH}$ at $\delta \mathrm{H} 8.34$ coupling with $\delta_{\mathrm{H}} 4.24(\mathrm{H} \alpha-\mathrm{Gln})$. The presence of two protons $(\mathrm{H} \alpha 1$ and $\mathrm{H} \beta 2)$ coupling to a $\mathrm{HN}\left(\delta_{\mathrm{N}} 75\right)$ in COSY, the HMBC correlations of $\mathrm{H} \alpha 1$ and $\mathrm{H} \beta 2$ to a carbonyl at $\delta_{\mathrm{c}} 157$, and a NOESY NMR spectrum $\left(600 \mathrm{MHz}\right.$ Bruker spectrometer in DMSO-d6 at $\left.25^{\circ} \mathrm{C}\right)$ of desoxy-PUM indicated the presence of glycine C-linked to glutamine $\mathrm{N} \alpha$. The chemical shift $\mathrm{HN}\left(\delta_{\mathrm{N}} 75\right)$ with corresponding $\delta_{\mathrm{H}}$ 7.43 indicated the presence of formamidine C-linked to glycine $\mathrm{N} \alpha$.

The stereochemistry of the glutamine residue was established to be (L) by total hydrolysis followed by chiral GC-MS (Hewlett-Packard HP5985B GC-MS; procedures as described ${ }^{35}$ ). The stereochemistry of the ribose sugar was inferred to be $\mathrm{D}$ by analogy to the natural product pseudouridine and was confirmed to be $\mathrm{D}$ by comparison of desoxy-PUM prepared by reduction of PUM with $\mathrm{TiCl}_{3}$ to desoxy-PUM prepared by total synthesis using a D-ribose precursor (Extended Data Fig. 7a-b).

\section{Effects of PUM on macromolecular synthesis}

Cultures of Staphylococcus simulans strain M22 in 0.5x Mueller Hinton II broth (BD Biosciences) were incubated at $37^{\circ} \mathrm{C}$ with shaking until $\mathrm{OD}_{600}=0.5$; diluted in the same medium to $\mathrm{OD}_{600}$ $=0.1-0.2$; supplemented with $6 \mathrm{kBq} / \mathrm{ml}\left[2{ }^{14} \mathrm{C}\right]$-thymidine (Hartmann Analytic), $40 \mathrm{kBq} / \mathrm{ml}\left[5-{ }^{3} \mathrm{H}\right]$-uridine (Hartman Analytic), or $6 \mathrm{kBq} / \mathrm{ml} \mathrm{L}-\left[{ }^{14} \mathrm{C}(\mathrm{U})\right]$-isoleucine (Hartman Analytic); and further incubated at $37^{\circ} \mathrm{C}$ with shaking. After $15 \mathrm{~min}$, cultures were divided into two equal aliquots, PUM was added to one aliquot to a final concentration of $100-200 \mu \mathrm{M}$, and cultures were further incubated at $37^{\circ} \mathrm{C}$ with shaking. At time points $0,10,20$, and $40 \mathrm{~min}$ following addition of PUM, $200 \mu \mathrm{l}$ aliquots were removed, mixed with $2 \mathrm{ml}$ ice-cold $10 \%$ TCA containing $1 \mathrm{M} \mathrm{NaCl}$, and incubated 30-60 min on ice. The resulting TCA precipitates were collected by filtration on glass-microfiber filters (GF/C; Whatman), and filters were washed with $5 \mathrm{ml} 2.5 \%$ TCA containing $1 \mathrm{M} \mathrm{NaCl}$, transferred to scintillation vials, and dried. Filtersafe scintillation fluid was added ( $2 \mathrm{ml}$; Zinnser Analytic), and radioactivity was quantified by scintillation counting (Tri-Carb 3110TR Liquid Scintillation Analyzer; PerkinElmer).

\section{RNAP-inhibitory activity in vitro}

For experiments in Fig. $1 \mathrm{~b}$ and Extended Data Table 1 assessing promoter-dependent transcription by $E$. coli RNAP, reaction mixtures contained $(25 \mu 1): 0-20 \mu \mathrm{M}$ PUM, 1 U E. coli RNAP $\sigma^{70}$ holoenzyme (Epicentre), $10 \mathrm{nM}$ DNA fragment carrying positions -112 to -1 of $E$. coli recA promoter ${ }^{36}$ followed by transcribed-region positions +1 to +363 of HeLaScribe Positive Control DNA (Promega; sequence at https://www.ncbi.nlm.nih.gov/pmc/articles/PMC4021065/bin/1471-2199-15-7-S1.docx; yields $363 \mathrm{nt}$ transcript), $20 \mu \mathrm{M}\left[\alpha^{32} \mathrm{P}\right] \mathrm{GTP}$ (0.3 Bq/fmol; PerkinElmer), $400 \mu \mathrm{M}$ ATP, $400 \mu \mathrm{M} \mathrm{CTP}$, and $6.25 \mu \mathrm{M}, 50 \mu \mathrm{M}$, or $250 \mu \mathrm{M}$ UTP, in $10 \mathrm{mM}$ Tris- $\mathrm{HCl}$ (pH. 7.8), $2 \mathrm{mM}$ HEPES-NaOH, $40 \mathrm{mM} \mathrm{KCl,} 3$ $\mathrm{mM} \mathrm{MgCl}$, $0.2 \mathrm{mM}$ dithiothreitol, $0.09 \mathrm{mM}$ EDTA, $0.2 \mathrm{mM}$ phenylmethylsulfonyl fluoride, and 10\% glycerol. Reaction components except RNAP were pre-equilibrated $10 \mathrm{~min}$ at $30^{\circ} \mathrm{C}$. Reactions were initiated by addition of RNAP, were allowed to proceed $15 \mathrm{~min}$ at $30^{\circ} \mathrm{C}$, and were terminated by addition of $175 \mu \mathrm{l} \mathrm{HeLa} \mathrm{Extract} \mathrm{Stop} \mathrm{Solution} \mathrm{(Promega).} \mathrm{Samples} \mathrm{were} \mathrm{phenol} \mathrm{extracted} \mathrm{and} \mathrm{ethanol} \mathrm{precipitated}$ 
(procedures as described $^{37}$ ), and pellets were resuspended in $10 \mu 147.5 \%$ formamide, $10 \mathrm{mM}$ EDTA, $0.025 \%$ bromophenol blue, and $0.01 \%$ xylene cyanol and heated $5 \mathrm{~min}$ at $95^{\circ} \mathrm{C}$. Products were applied to $6 \%$ polyacrylamide (19:1 acrylamide:bisacrylamide; $7 \mathrm{M}$ urea $)^{37}$ slab gels, and gels were electrophoresed in $\mathrm{TBE}^{37}$ at $10 \mathrm{~V} / \mathrm{cm}$ for $1.5 \mathrm{~h}$, dried using a gel dryer (BioRad) ${ }^{37}$, and analyzed by storage-phosphor imaging (Typhoon; GE Healthcare).

For experiments in Fig. 1b and Extended Data Table 1 assessing promoter-dependent transcription by human RNAP I, human RNAP II, and human RNAP III, reaction mixtures contained (25 $\mu 1): 0-80 \mu \mathrm{M}$ PUM, HeLa nuclear extract [ $3 \mu \mathrm{l} \mathrm{HeLa} \mathrm{nuclear} \mathrm{extract} \mathrm{prepared} \mathrm{as} \mathrm{described}{ }^{38}$, using $\sim 4 \times 10^{7} \mathrm{HeLa}$ cells grown to $70-80 \%$ confluence in DMEM, high glucose, $2 \mathrm{mM}$ L-glutamine medium containing 10\% fetal bovine serum (Gibco) and 1\% penicillin-streptomycin (Gibco) for assays of human RNAP I; or 6 U HeLaScribe Nuclear Extract (Promega) for assays of human RNAP II and human RNAP III], promoter DNA [ $4 \mathrm{nM}$ EcoRI-linearized plasmid $\mathrm{pHrP} 2 \mathrm{x}^{39}$ carrying human rDNA promoter for assays of human RNAP I (yields $379 \mathrm{nt}$ transcript; $20 \mathrm{nM}$ HeLaScribe Positive Control DNA (Promega) carrying cytomegalovirus immediate early promoter for assays of human RNAP II (yields $363 \mathrm{nt}$ transcript with same sequence as E.-coli-RNAP-dependent transcript of preceding paragraph); or $2 \mathrm{nM}$ plasmid $\mathrm{pVAI}^{40}$ carrying adenovirus VAI promoter for assays of human RNAP III (yields $160 \mathrm{nt}$ transcript)], $20 \mu \mathrm{M}\left[\alpha^{32} \mathrm{P}\right] \mathrm{GTP}(0.3 \mathrm{~Bq} /$ fmol: PerkinElmer $), 400 \mu \mathrm{M}$ ATP, $400 \mu \mathrm{M} \mathrm{CTP}$, and 6.25, 50, or $250 \mu \mathrm{M}$ UTP, in transcription buffer [12 mM HEPES-NaOH (pH 7.9), $75 \mathrm{mM} \mathrm{KCl,} 5 \mathrm{mM} \mathrm{MgCl} 2,10$ $\mathrm{mM}$ creatine phosphate, $0.5 \mathrm{mM}$ dithiothreitol, $0.1 \mathrm{mM}$ EDTA, and $12 \%$ glycerol, for assays with human RNAP I; 10 mM Tris- $\mathrm{HCl}$ (pH 7.8), $2 \mathrm{mM}$ HEPES-NaOH, $44 \mathrm{mM} \mathrm{KCl}, 3 \mathrm{mM} \mathrm{MgCl}, 0.2 \mathrm{mM}$ dithiothreitol, $0.09 \mathrm{mM}$ EDTA, $0.2 \mathrm{mM}$ phenylmethylsulfonyl fluoride, and $10 \%$ glycerol, for assays with human RNAP II and human RNAP III]. Procedures were as in the preceding paragraph.

For experiments in Fig. $1 \mathrm{~b}$ assessing transcription by B. subtilis RNAP, SP6 RNAP, and T7 RNAP, , reaction mixtures contained (50 $\mu \mathrm{l}): 0-200 \mu \mathrm{M}$ PUM, RNAP [0.2 U nM Rif-resistant B. subtilis [469 (513) Gln $\rightarrow$ Arg] $\beta$-RNAP $\sigma^{\mathrm{A}}$ holoenzyme (units defined as described ${ }^{30}$ ), 0.2 U SP6 RNAP (Promega), or 0.2 U T7 RNAP (Promega), DNA [0.2 nM plasmid pUC18 (Clontech; for assays with $B$. subtilis RNAP), or $0.2 \mathrm{nM}$ plasmid pGEM-3Z (Promega; for assays with SP6 RNAP and T7 RNAP)], 500 $\mu \mathrm{M}$ ATP, $500 \mu \mathrm{M}$ GTP, $500 \mu \mathrm{M}$ CTP, and $6.25 \mu \mathrm{M}\left[\alpha^{32} \mathrm{P}\right] \mathrm{UTP}(0.2 \mathrm{~Bq} / \mathrm{fmol}$; PerkinElmer; 6.25, 50, or $250 \mu \mathrm{M}$ for Extended Data Table 1), in $40 \mathrm{mM}$ Tris- $\mathrm{HCl}$ (pH 7.9), $6 \mathrm{mM} \mathrm{MgCl} 2,2 \mathrm{mM}$ spermidine, 10 $\mathrm{mM} \mathrm{NaCl}, 10 \mathrm{mM}$ dithiothreitol, and $10 \mu \mathrm{g} / \mathrm{ml}$ bovine serum albumin. Reaction components except DNA were pre-equilibrated $15 \mathrm{~min}$ at $37^{\circ} \mathrm{C}$. Reactions were initiated by addition of DNA, were allowed to proceed $15 \mathrm{~min}$ at $37^{\circ} \mathrm{C}$, and were terminated by addition of $150 \mu \mathrm{l}$ ice-cold $10 \%(\mathrm{w} / \mathrm{v}) \mathrm{TCA}$. After 30 min on ice, the resulting TCA precipitates were collected on glass-fiber filters (UniFilter GF/C; PerkinElmer) using a 96-well harvester (Packard). filters were washed once with water, and radioactivity was quantified using a TopCount scintillation counter (Packard).

For experiments in Fig. $1 \mathrm{~b}$ assessing transcription by $\phi 6$ RNA-dependent RNAP, reaction mixtures contained (20 $\mu$ l): 0-400 $\mu$ M PUM, 0.5 U $\phi 6$ RNAP (Thermo Fisher), $2 \mu$ g poly(A) ssRNA (GE Healthcare), $1 \mu \mathrm{M}$ poly(U-15) ssRNA primer (Sigma-Aldrich), $400 \mu \mathrm{M}$ ATP, $400 \mu \mathrm{M}$ GTP, $400 \mu \mathrm{M}$ $\mathrm{CTP}$, and $1.56 \mu \mathrm{M}\left[\alpha^{32} \mathrm{P}\right] \mathrm{UTP}(0.02 \mathrm{~Bq} / \mathrm{fmol}$; Perkin-Elmer) in $50 \mathrm{mM}$ Tris-acetate (pH 8.7), $50 \mathrm{mM}$ ammonium acetate, and $1.5 \mathrm{mM} \mathrm{MnCl}$. Reaction components other than RNA template, RNA primer, and NTPs were pre-incubated $10 \mathrm{~min}$ at $30^{\circ} \mathrm{C}$. Reactions were initiated by addition of RNA template, RNA primer, and NTPs, reactions were allowed to proceed $1 \mathrm{~h} \mathrm{~min}$ at $30^{\circ} \mathrm{C}$, and reactions were terminated by spotting on DE81 filter discs (Whatman; pre-wetted with water) and incubating $1 \mathrm{~min}$ at $22^{\circ} \mathrm{C}$. Filters were washed with $3 \times 3 \mathrm{ml} 0.5 \mathrm{M}$ sodium phosphate dibasic, $2 \times 3 \mathrm{ml}$ water, and $3 \mathrm{ml}$ ethanol using a filter manifold (Hoefer); filters were placed in scintillation vials containing $10 \mathrm{ml}$ Scintiverse BD Cocktail (Thermo Fisher); and radioactivity was quantified by scintillation counting (LS6500; BeckmanCoulter).

For experiments in Extended Data Table 1 assessing promoter-independent transcription by $E$. coli RNAP and HeLa nuclear extract (human RNAP I/II/II), reaction mixtures contained (20 $\mu 1): 0-100$ $\mu \mathrm{M}$ PUM, $100 \mathrm{nM}$ E. coli RNAP core enzyme or $8 \mathrm{U}$ HeLaScribe Nuclear Extract (Promega), $1 \mu \mathrm{g}$ 
human placental DNA (Sigma-Aldrich; catalog number D7011), $400 \mu \mathrm{M}$ ATP, $400 \mu \mathrm{M} \mathrm{GTP}$, and 400 $\mu \mathrm{M}$ CTP, and 1.56, 25, or $400 \mu \mathrm{M}\left[\alpha^{32} \mathrm{P}\right] \mathrm{UTP}(0.1-1 \mathrm{~Bq} / \mathrm{fmol}$; PerkinElmer), in $40 \mathrm{mM}$ Tris- $\mathrm{HCl}(\mathrm{pH}$ 8.0), $7 \mathrm{mM}$ HEPES-NaOH, $70 \mathrm{mM}$ ammonium sulfate, $30 \mathrm{mM} \mathrm{KCl}, 12 \mathrm{mM} \mathrm{MgCl}, 5 \mathrm{mM}$ dithiothreitol, $0.1 \mathrm{mM}$ EDTA, and $12 \%$ glycerol. Procedures were performed as described ${ }^{18}$.

For experiments in Extended Data Figs. 4c and 7c, fluorescence-detected transcription assays were performed essentially as described ${ }^{5}$.

Half-maximal inhibitory concentrations (IC50s) were calculated by non-linear regression in SigmaPlot (Systat Software).

\section{Antibacterial activity in vitro}

Antibacterial activities in vitro (Fig. 1c, rows 1-20; Extended Data Fig. 7d) were determined using broth-microdilution growth-curve assays ${ }^{41}$ (PUM degrades in phosphate-containing media with a half-life of $\sim 12 \mathrm{~h}$. Broth-microdilution endpoint assays ${ }^{42}$, which have a run time of 16-24 $\mathrm{h}^{42}$, which corresponds to 1.3 to 2 PUM half-lives, under-estimate absolute antibacterial activities of PUM. Broth-microdilution growth-curve assays ${ }^{41}$, which have shorter run times between assay start and assay signal, more accurately estimate absolute antibacterial activities of PUM.) Colonies of the indicated bacterial strains (5 to 10 per strain) were suspended in $3 \mathrm{ml}$ phosphate-buffered saline ${ }^{37}$, suspensions were diluted to $1 \times 10^{5} \mathrm{cfu} / \mathrm{ml}$ with growth medium [Todd Hewitt broth (BD Biosciences) for Streptococcus pyogenes and Streptococcus pneumoniae, aged Mueller Hinton II cation-adjusted broth (BD Biosciences; autoclaved and allowed to stand 2-12 months at room temperature before use) for Staphylococcus aureus and Enterococcus faecium, fresh Mueller Hinton II cation-adjusted broth (autoclaved and used immediately) for Moraxella catarrhalis, or fresh Mueller Hinton II cation-adjusted broth (BD Biosciences; autoclaved and used immediately) containing 0.4\% Haemophilus Test Medium ${ }^{43}$ and $0.5 \%$ yeast extract for Haemophilus influenzae], $50 \mu$ aliquots were dispensed into wells of a 96-well microplate containing $50 \mu \mathrm{l}$ of the same medium or $50 \mu \mathrm{l}$ of a 2-fold dilution series of PUM in the same medium (final concentrations $=0$ and $0.25-256 \mu \mathrm{M}$ ), plates were incubated at $37^{\circ} \mathrm{C}$ with shaking, and optical densities at $600 \mathrm{~nm}$ were recorded at least hourly using a Synergy 2 (BioTek) or GENios Pro (Tecan) microplate reader. For each dilution series, growth curves were plotted, areas under growth curves were calculated, and IC50 was extracted as the lowest tested concentration of PUM that reduced area under the growth curve to 50\% that in the absence of PUM (using only time points for rise phase of the growth curve in the absence of PUM).

Identical results were obtained in assays in the absence and presence of $30 \%$ human serum (Sigma-Aldrich; Fig. 1c, rows 1-4), indicating that PUM does not bind tightly to human serum proteins (unbound fraction $\sim 100 \%$ ).

Cytotoxicities for human macrovascular endothelial cells and human monocytes in culture (Fig. 1c, rows 21-22) were determined as described ${ }^{44}$.

\section{Antibacterial activity in vivo}

Antibacterial activity in vivo was assessed in a mouse $S$. pyogenes peritonitis model (Fig. 1d; Extended Data Table 2). Female ICR mice (weight $=23-25 \mathrm{~g}$; Harlan Laboratories Italy) were adapted to standardized environmental conditions (temperature $=23 \pm 2{ }^{\circ} \mathrm{C}$; humidity $=55 \% \pm 10 \%$ ) for one week prior to infection. Infection was induced by intraperitoneal injection of $0.5 \mathrm{ml}$ saline solution (supplemented with $1 \%$ peptone) containing $4 \times 10^{3} \mathrm{cfu}$ S. pyogenes $\mathrm{C} 203$ (an inoculum resulting in $\geq 95 \%$ mortality in untreated controls within 48 to $72 \mathrm{~h}$ after infection). Infected mice (eight mice per group; number determined by power calculations; assigned randomly to groups; unblinded) were treated with either: (i) $0.2 \mathrm{ml} \mathrm{5 \%}$ dextrose or $0.2 \mathrm{ml}$ of a 2.5 -fold dilution series of PUM in $5 \%$ dextrose, administered intravenously $10 \mathrm{~min}$ after infection and again $6 \mathrm{~h}$ after infection (total PUM dose $=0$ or $3.2-50 \mathrm{mg} / \mathrm{kg}$ ), (ii) $0.25 \mathrm{ml} 5 \%$ dextrose or $0.25 \mathrm{ml}$ of a 2.5 -fold dilution series of PUM in $5 \%$ dextrose, administered intravenously 10 min after infection (total PUM dose $=0$ or $1.024-40 \mathrm{mg} / \mathrm{kg}$ ), or (iii) or 0.25 $\mathrm{ml} \mathrm{5 \%}$ dextrose or $0.25 \mathrm{ml}$ of a 2.5 -fold dilution series of PUM in 5\% dextrose, administered 
subcutaneously $10 \mathrm{~min}$ after infection (total PUM dose $=0$ or $1.024-40 \mathrm{mg} / \mathrm{kg}$ ). Survival was monitored for 7 days after infection. Experiments were performed in compliance with vertebrate animal ethical regulations and with Institutional Animal Care and Use Committee (IACUC) approval.

ED50s (doses yielding 50\% survival at 7 days) and 95\% confidence limits were calculated using the trimmed Spearman-Karber method as implemented in the US EPA LC50 Model System (http://sdi.odu.edu/model/1c50.php) $)^{45}$.

\section{Checkerboard interaction assays}

Antibacterial activities of combinations of PUM and Rif were assessed in checkerboard interaction assays ${ }^{46-47}$ (Fig. 1e). Broth-macrodilution (assays procedures essentially as described ${ }^{42}$ ) were performed in checkerboard format, using S. pyogenes strain L49 or S. pneumoniae strain L44, and using Todd Hewitt broth (BD Biosciences) containing pairwise combinations of: (i) PUM at $1 \mathrm{x}, 0.5 \mathrm{x}, 0.25 \mathrm{x}$, $0.125 \mathrm{x}, 0.063 \mathrm{x}, 0.031 \mathrm{x}, 0.016 \mathrm{x}$, and $0.0078 \mathrm{x} \mathrm{MIC}_{\mathrm{PUM}}$ and (ii) Rif at $0.8 \mathrm{x}, 0.4 \mathrm{x}, 0.2 \mathrm{x}, 0.1 \mathrm{x}, 0.05 \mathrm{x}, 0.025 \mathrm{x}$, and $0.0125 \mathrm{x} \mathrm{MIC}_{\mathrm{Rif}}$. Fractional inhibitory concentrations (FICs), FIC indices (FICIs), and minimum and maximum FICIs $\left(\right.$ FICI $_{\min }$ and FICI $_{\max }$ ) were calculated as described ${ }^{47}$. FICI $\mathrm{Im}_{\min } \leq 0.5$ was deemed indicative of super-additivity (synergism), $\mathrm{FICI}_{\min }>0.5$ and $\mathrm{FICI}_{\max } \leq 4.0$ was deemed indicative of additivity, and FICI $_{\max }>4.0$ was deemed indicative of sub-additivity (antagonism) ${ }^{46-47}$.

\section{Spontaneous resistance rate assays}

Spontaneous resistance rates were determined in Luria-Delbrück fluctuation assays ${ }^{48}$ (Fig. 2a). S. pyogenes strain ATCC $12344\left(\sim 1 \times 10^{9} \mathrm{cfu} /\right.$ plate) was plated on Todd Hewitt agar [Todd Hewitt broth (BD Biosciences) supplemented with 1.5\% Bacto agar (BD Biosciences)] containing $64 \mu \mathrm{g} / \mathrm{ml}$ or 128 $\mu \mathrm{g} / \mathrm{ml}$ PUM (8x or 16x MIC under these conditions) or $1 \mu \mathrm{g} / \mathrm{ml}$ or $2 \mu \mathrm{g} / \mathrm{ml}$ Rif (8x or 16x MIC under these conditions), and numbers of colonies were counted after $24 \mathrm{~h}$ at $37^{\circ} \mathrm{C}$ (at least six independent determinations each). Resistance rates and 95\% confidence intervals were calculated using the MaSandri-Sarkar Maximum Likelihood Estimator ${ }^{49-50}$ as implemented on the Fluctuation Analysis Calculator (http://www.keshavsingh.org/protocols/FALCOR.html) ${ }^{51}$.

\section{Spontaneous PUM-resistant mutants, S. pyogenes.}

To isolate spontaneous PUM-resistant mutants of $S$. pyogenes (Fig. 2b), a single colony of $S$. pyogenes ATCC 12344 was inoculated into $5 \mathrm{ml}$ Todd Hewitt broth (BD Biosciences) and incubated $3 \mathrm{~h}$ at $37^{\circ} \mathrm{C}$ with shaking in a $7 \% \mathrm{CO}_{2} / 6 \% \mathrm{O}_{2} / 4 \% \mathrm{H}_{2} / 83 \% \mathrm{~N}_{2}$ atmosphere (atmosphere controlled using Anoxomat AN2CTS; Advanced Instruments), the culture was centrifuged, and the cell pellet $\left(\sim 1 \times 10^{9}\right.$ cells) was re-suspended in $50 \mu \mathrm{l}$ Todd Hewitt broth and plated on Todd Hewitt agar (BD Biosciences) containing 16-256 $\mu \mathrm{g} / \mathrm{ml}$ PUM (2-32x MIC under these conditions), and plates were incubated $120 \mathrm{~h}$ at $37^{\circ} \mathrm{C}$ in a $7 \% \mathrm{CO}_{2} / 6 \% \mathrm{O}_{2} / 4 \% \mathrm{H}_{2} / 83 \% \mathrm{~N}_{2}$ atmosphere. PUM-resistant mutants were identified by the ability to form colonies on these media, were confirmed to be PUM-resistant by re-streaking on the same media, and were confirmed to be $S$. pyogenes, (as opposed to contaminants) using Taxo A differentiation discs (BD Biosciences) and Pyrase strips (Fluka).

Genomic DNA was isolated using the Wizard Genomic DNA Purification Kit [Promega; procedures as specified by the manufacturer, but with cells lysed using $1 \mathrm{mg} / \mathrm{ml}$ lysozyme (Sigma-Aldrich)] and was quantified by measurement of UV-absorbance (procedures as described ${ }^{37}$ ). The rpoC gene and the $r p o B$ gene were PCR-amplified in reactions containing $0.2 \mu$ g genomic DNA, $0.4 \mu \mathrm{M}$ forward and reverse oligodeoxyribonucleotide primers (5'-GGGCAAATGATAACTTAGTTGCGATTTGCTG-3' and 5'-CCTTTCTGCCTTTGATGACTTTACCAGTTC-3' for rpoB; 5'-GCTCAAGAAACTCAAGAAGTTTCTGAAACAACTGAC-3' and 5'-GTCAATGCTTTTTACTGCCAACAAACTCAGAC-3' for $r p o C)$, $5 \mathrm{U}$ Taq DNA polymerase (Genscript), and $800 \mu \mathrm{M}$ dNTP mix $(200 \mu \mathrm{M}$ each dNTP; Agilent/Stratagene) (initial denaturation step of $3 \mathrm{~min}$ at $94^{\circ} \mathrm{C} ; 30$ cycles of $30 \mathrm{~s}$ at $94^{\circ} \mathrm{C}, 45 \mathrm{~s}$ at $53^{\circ} \mathrm{C}$, and $4 \mathrm{~min}$ at $68^{\circ} \mathrm{C}$; final extension step of $10 \mathrm{~min}$ 
at $\left.68^{\circ} \mathrm{C}\right)$. PCR products containing the $r p o C$ gene $(3.6 \mathrm{kB})$ or the rpoB gene $(3.6 \mathrm{kB})$ were isolated by electrophoresis on $0.8 \%$ agarose gels (procedures as described ${ }^{37}$ ), extracted from gel slices using a Gel/PCR DNA Fragments Extraction Kit (IBI Scientific; procedures as specified by the manufacturer), and sequenced (GENEWIZ; Sanger sequencing; seven sequencing primers per gene).

\section{Spontaneous PUM-resistant mutants, $E$. coli}

To isolate spontaneous PUM-resistant mutants of E. coli (Extended Data Fig. 4a), E. coli uptake-proficient, efflux-deficient strain D21f2tolC ${ }^{52}$ was cultured to saturation in $10 \mathrm{ml} \mathrm{LB}$ broth ${ }^{37}$ at $37^{\circ} \mathrm{C}$, cultures were centrifuged, cell pellets $\left(\sim 1 \times 10^{10}\right.$ cells) were re-suspended in $50 \mu \mathrm{LB}$ broth and plated on LB agar ${ }^{37}$ containing $800 \mu \mathrm{g} / \mathrm{ml}$ PUM ( $1 \mathrm{x}$ MIC under these conditions), and plates were incubated $96-120 \mathrm{~h}$ at $37^{\circ} \mathrm{C}$. PUM-resistant mutants were identified by the ability to form colonies on this medium.

Genomic DNA was isolated, and rpoB and rpoC genes were PCR-amplified and sequenced as described ${ }^{18}$.

\section{Resistance and cross-resistance levels}

Resistance levels of S. pyogenes and E. coli spontaneous PUM-resistant mutants (Fig. 2b

Extended Data Fig. 4b) were quantified in broth-microdilution assays. A single colony of a mutant strain or the isogenic wild-type parent strain was inoculated into $5 \mathrm{ml}$ Todd Hewitt broth (BD Biosciences; for S. pyogenes) or $\mathrm{LB}$ broth $^{37}$ (for E. coli) and incubated at $37^{\circ} \mathrm{C}$ with shaking in a $7 \% \mathrm{CO}_{2} / 6 \% \mathrm{O}_{2} / 4 \% \mathrm{H}_{2} / 83 \% \mathrm{~N}_{2}$ atmosphere (atmosphere controlled using Anoxomat AN2CTS; Advanced Instruments); for S. pyogenes) or in air (for E. coli) until $\mathrm{OD}_{600}=0.4-0.8$. Diluted aliquots $\left(\sim 2 \times 10^{5}\right.$ cells in $50 \mu \mathrm{l}$ same medium) were dispensed into wells of a 96 -well microplate containing $50 \mu \mathrm{l}$ of the same medium or $50 \mu \mathrm{l}$ of a 2-fold dilution series of PUM in the same medium (final PUM concentration $=0$ or $0.098-800 \mu \mathrm{g} / \mathrm{ml}$ ), and were incubated $16 \mathrm{~h}$ at $37^{\circ} \mathrm{C}$ with shaking in a $7 \% \mathrm{CO}_{2} / 6 \% \mathrm{O}_{2} / 4 \% \mathrm{H}_{2} / 83 \% \mathrm{~N}_{2}$ atmosphere (for S. pyogenes) or in air (for E. coli). MIC was defined as the lowest tested concentration of PUM that inhibited bacterial growth by $\geq 90 \%$. MIC/MIC $\mathrm{Mild}_{\text {-type }}$ was defined as the ratio of MIC for mutant to MIC for isogenic wild-type parent (S. pyogenes $\mathrm{MIC}_{\text {wild-type }}=6.25 \mu \mathrm{g} / \mathrm{ml}$ under these conditions; $E$. coli $\mathrm{MIC}_{\text {wild-type }}=400 \mu \mathrm{g} / \mathrm{ml}$ under these conditions).

Cross-resistance levels of $S$. pyogenes and E. coli spontaneous PUM-resistant mutants (Fig. 2e; Extended Data Fig. 4f) were determined as in the preceding paragraph, but using culture aliquots $\left(\sim 1 \times 10^{5}\right.$ cells) in $97 \mu \mathrm{l}$ growth medium supplemented with $3 \mu \mathrm{l}$ methanol or $3 \mu \mathrm{l}$ of a 2-fold dilution series of Rif (Sigma-Aldrich; S. pyogenes $\mathrm{MIC}_{\text {wild-type }}=0.098 \mu \mathrm{g} / \mathrm{ml} ;$ E. coli $\mathrm{MIC}_{\text {wild-type }}=0.20 \mu \mathrm{g} / \mathrm{ml}$ ), lipiarmycin A3 (Lpm; BioAustralis; S. pyogenes $\mathrm{MIC}_{\text {wild-type }}=6.25 \mu \mathrm{g} / \mathrm{ml} ;$ E. coli $\mathrm{MIC}_{\text {wild-type }}=1.56 \mu \mathrm{g} / \mathrm{ml}$ ), myxopyronin $\mathrm{B}$ (Myx; prepared as described ${ }^{53}$; S. pyogenes $\mathrm{MIC}_{\text {wild-type }}=6.25 \mu \mathrm{g} / \mathrm{ml} ;$ E. coli $\mathrm{MIC}_{\text {wild-type }}=0.20 \mu \mathrm{g} / \mathrm{ml}$ ), streptolydigin (Stl; Sourcon-Padena; S. pyogenes $\mathrm{MIC}_{\text {wild-type }}=3.13 \mu \mathrm{g} / \mathrm{ml} ;$ E. coli $\mathrm{MIC}_{\text {wild-type }}=3.13$ $\mu \mathrm{g} / \mathrm{ml}$ ), CBR703 (CBR; Maybridge; E. coli $\mathrm{MIC}_{\text {wild-type }}=6.25 \mu \mathrm{g} / \mathrm{ml}$ ), or salinamide A (Sal; W. Fenical, Scripps Institution of Oceanography; E. coli $\mathrm{MIC}_{\text {wild-type }}=0.049 \mu \mathrm{g} / \mathrm{ml}$ ) in methanol (final concentrations $=0$ and $0.006-50 \mu \mathrm{g} / \mathrm{ml})$, or using culture aliquots $\left(\sim 2 \times 10^{5}\right)$ cells in $50 \mu 1$ growth medium supplemented with $50 \mu$ l growth medium or $50 \mu 1$ of a 2 -fold dilution series of GE23077 (GE; prepared as described ${ }^{54}$; E. coli $\mathrm{MIC}_{\text {wild-type }}=500 \mu \mathrm{g} / \mathrm{ml}$ ) in growth medium (final concentrations $=0$ and $125-8000 \mu \mathrm{g} / \mathrm{ml}$ ).

Cross-resistance levels of $S$. pyogenes Rif-resistant mutants to PUM (Fig. 1e) were determined were determined as described for cross-resistance levels of S. pyogenes spontaneous PUM-resistant mutants, but analyzing a collection of 13 S. pyogenes spontaneous Rif-resistant mutants [isolated and sequenced using the same procedures used for isolation and sequencing of $S$. pyogenes PUM-resistant mutants (Methods, Spontaneous PUM-resistant mutants, S. pyogenes), but using Todd Hewitt agar containing 1-16x MIC Rif (0.1-2 $\mu \mathrm{g} / \mathrm{ml}$ under these conditions)] and the isogenic wild-type parent, and analyzing a 2-fold dilution series of PUM (final concentration $=0$ or $1.56-100 \mu \mathrm{g} / \mathrm{ml}$ ).

Cross-resistance levels of E. coli Rif-, Lpm-, Myx-, and Sal-resistant mutants to PUM (Extended Data Fig. 4g-i,l) were determined as described for resistance levels of $E$. coli spontaneous PUM-resistant mutants, but analyzing a collection of $E$. coli D21f2tolC derivatives ${ }^{18}$ comprising four chromosomal Rif- 
resistant mutants, five chromosomal Lpm-resistant mutants, five chromosomal Myx-resistant mutants, five chromosomal Sal-resistant mutants, and the isogenic wild-type parent, and analyzing a 2-fold dilution series of PUM (final concentration $=0$ or $25-1600 \mu \mathrm{g} / \mathrm{ml}$ ).

Cross-resistance levels of E. coli Stl-, CBR-, and GE-resistant mutants to PUM (Extended Data Fig. 4j-k,n) were determined analogously, analyzing a collection of E. coli D21f2tolC pRL706 and E. coli D21f2tolC pRL663 derivatives ${ }^{5,14,16}$ comprising five plasmid-based Stl-resistant mutants, five plasmidbased CBR-resistant mutants, six plasmid-based GE-resistant mutants, and plasmid-based wild-type isogenic parents. Single colonies were inoculated into $5 \mathrm{ml} \mathrm{LB}$ broth containing $200 \mu \mathrm{g} / \mathrm{ml}$ ampicillin (Sigma-Aldrich), incubated at $37^{\circ} \mathrm{C}$ with shaking until $\mathrm{OD}_{600}=0.4-0.8$, supplemented with IPTG (Gold Bio) to a final concentration of $1 \mathrm{mM}$, and further incubated $1 \mathrm{~h}$ at $37^{\circ} \mathrm{C}$ with shaking. Diluted aliquots $\left(\sim 2 \times 10^{5}\right.$ cells in $50 \mu \mathrm{LB}$ broth containing $200 \mu \mathrm{g} / \mathrm{ml}$ ampicillin and $1 \mathrm{mM}$ IPTG) were dispensed into wells of a 96-well microplate containing $50 \mu \mathrm{l}$ of the same medium or $50 \mu \mathrm{l}$ of a 2-fold dilution series of PUM in the same medium (final concentration $=0$ or $25-4000 \mu \mathrm{g} / \mathrm{ml}$ ), and were incubated $16 \mathrm{~h}$ at $37^{\circ} \mathrm{C}$ with shaking.

Amino-acid substitutions that confer PUM-resistance in the context of $S$. pyogenes RNAP were re-constructed and re-analyzed in the context of E. coli RNAP using an E. coli plasmid-based resistance assay (Extended Data Fig. 4b). Site-directed mutagenesis (QuikChange Site-Directed Mutagenesis Kit; Agilent) was used to construct plasmid pRL $706^{28}$ and pRL663 ${ }^{55}$ derivatives encoding E. coli RNAP $\beta$-subunit and $\beta$ '-subunit derivatives having amino-acid substitutions that confer PUM-resistance in $S$. pyogenes (sequences from Fig. $2 b$ ). The resulting plasmids were introduced by transformation into $E$. coli strain D21f2tolC ${ }^{52}$, and resistance levels of transformants were determined using the procedures of the preceding paragraph.

\section{Formation of RNAP-promoter open complex}

Experiments (Extended Data Fig. 4a) were performed essentially as described ${ }^{12}$. Reaction mixtures contained $(20 \mu \mathrm{l})$ : test compound ( 0 or $500 \mu \mathrm{M}$ PUM, $2 \mu \mathrm{M}$ Rif, or $100 \mu \mathrm{M} \mathrm{Lpm}), 40 \mathrm{nM}$ E. coli RNAP $\sigma^{70}$ holoenzyme, $10 \mathrm{nM}$ Cy5-labelled DNA fragment carrying positions -40 to +15 of lacUV5 promoter (lacUV5-[-40;+15]-Cy5 ${ }^{12}$ ), and $100 \mu \mathrm{g} / \mathrm{ml}$ heparin, in $50 \mathrm{mM}$ Tris- $\mathrm{HCl}$ (pH 8.0), $100 \mathrm{mM} \mathrm{KCl,}$ $10 \mathrm{mM} \mathrm{MgCl} 2,1 \mathrm{mM}$ dithiothreitol, $10 \mu \mathrm{g} / \mathrm{ml}$ bovine serum albumin, and 5\% glycerol. Reaction components other than DNA and heparin were incubated $10 \mathrm{~min}$ at $37^{\circ} \mathrm{C}$; DNA was added and reactions were incubated $15 \mathrm{~min}$ at $37^{\circ} \mathrm{C}$; and heparin was added and reactions were incubated 2 min at $37^{\circ} \mathrm{C}$. Products were applied to 5\% TBE-polyacrylamide slab gels (Bio-Rad), electrophoresed in $\mathrm{TBE}^{37}$, and analyzed by fluorescence scanning (Typhoon 9400).

\section{Nucleotide addition in transcription initiation.}

Experiments were performed essentially as described ${ }^{5}$, using reaction mixtures that contained no inhibitor, $500 \mu \mathrm{M}$ PUM, $2 \mu \mathrm{M}$ Rif, or $100 \mu \mathrm{M}$ Lpm, and using $5 \mu \mathrm{M}\left[\alpha^{32} \mathrm{P}\right] \mathrm{UTP}(3 \mathrm{~Bq} / \mathrm{fmol}$; PerkinElmer) (Extended Data Fig. 4b).

\section{Nucleotide addition in transcription elongation}

Experiments were performed essentially as described ${ }^{5}$, using reaction mixtures that contained no inhibitor, $500 \mu \mathrm{M}$ PUM, $2 \mu \mathrm{M}$ Rif, or $100 \mu \mathrm{M}$ Lpm (Extended Data Fig. 4c).

\section{Nucleotide addition at elevated NTP concentrations}

Experiments (Fig. 3a) were performed essentially as described above for assays of promoter-dependent transcription by $B$. subtilis RNAP (Methods, RNAP-inhibitory activity in vitro), using reaction mixtures $(50 \mu \mathrm{l})$ that contained 0 or $6 \mu \mathrm{M}$ PUM, $0.4 \mathrm{U}$ E. coli RNAP $\sigma^{70}$ holoenzyme (Epicentre), $0.4 \mathrm{nM}$ plasmid pUC19 Clontech), $80 \mathrm{mM}$ HEPES-KOH (pH 7.5), $80 \mathrm{mM} \mathrm{KCl,} 4 \mathrm{mM}$ $\mathrm{MgCl}_{2}, 0.1 \mathrm{mM}$ EDTA, $5 \mathrm{mM}$ dithiothreitol, $100 \mu \mathrm{g} / \mathrm{ml}$ bovine serum albumin, and either (i) $100 \mu \mathrm{M}$ ATP, $100 \mu \mathrm{M}\left[\alpha^{32} \mathrm{P}\right] \mathrm{CTP}(0.2 \mathrm{~Bq} /$ fmol; PerkinElmer), $100 \mu \mathrm{M}$ GTP, and 10-500 $\mu \mathrm{M}$ UTP; (ii) 10-500 
$\mu \mathrm{M}$ GTP, $100 \mu \mathrm{M}$ ATP, $100 \mu \mathrm{M}$ CTP, and $2 \mu \mathrm{M}\left[\alpha^{32} \mathrm{P}\right] \mathrm{UTP}$ (0.2 Bq/fmol; PerkinElmer); (iii) $100 \mu \mathrm{M}$ GTP, $10-500 \mu \mathrm{M}$ A, $100 \mu \mathrm{M}$ CTP, and $2 \mu \mathrm{M}\left[\alpha^{32} \mathrm{P}\right] \mathrm{UTP}(0.2 \mathrm{~Bq} / \mathrm{fmol})$; or (iv) $100 \mu \mathrm{M}$ GTP, $100 \mu \mathrm{M}$ ATP, $10-500 \mu \mathrm{M} \mathrm{CTP}$, and $2 \mu \mathrm{M}\left[\alpha^{32} \mathrm{P}\right] \mathrm{UTP}(0.2 \mathrm{~Bq} / \mathrm{fmol})$. The reaction time was $30 \mathrm{~min}$ at $37^{\circ} \mathrm{C}$. Relative nucleotide incorporation was defined as the ratio of nucleotide incorporation in the presence of PUM to nucleotide incorporation in the absence of PUM.

\section{Nucleotide addition on standard and "U-less cassette" templates}

Experiments (Fig. 3b) were performed essentially as described in the preceding section (Methods, Nucleotide addition at elevated NTP concentrations), using reaction mixtures (50 $\mu \mathrm{l})$ that contained 0-20 $\mu \mathrm{M}$ PUM, 0.4 U E. coli RNAP $\sigma^{70}$ holoenzyme (Epicentre), $2 \mu \mathrm{M}\left[\alpha^{32} \mathrm{P}\right] \mathrm{CTP}(0.2 \mathrm{~Bq} / \mathrm{fmol}$; PerkinElmer), $100 \mu \mathrm{M}$ ATP, $100 \mu \mathrm{M}$ GTP, and $5 \mu \mathrm{M}$ UTP, in $40 \mathrm{mM}$ Tris- $\mathrm{HCl}(\mathrm{pH} 7.5), 10 \mathrm{mM} \mathrm{MgCl} 2,5 \mathrm{mM}$ dithiothreitol, $15 \mathrm{mM} \mathrm{KCl}, 0.01 \%$ Triton X-100, and $100 \mu \mathrm{g} / \mathrm{ml}$ bovine serum albumin, and either (i) 50 nM DNA fragment carrying positions -112 to +8 of E. coli recA promoter ${ }^{36}$ followed by 5'-CAGGGACAAGTTAGTTCGTTCAGCGACACGCGGCAACAAG-3' (directs incorporation of U, G, $\mathrm{A}$, and C) or (ii) $50 \mathrm{nM}$ DNA fragment carrying positions -112 to +8 of E. coli recA promoter followed by 5'-CAGGGACAAGGAGACCAACGCAGCGACACGCGGCAACAAG-3' ("U-less cassette"; directs incorporation of $\mathrm{G}, \mathrm{A}$, and $\mathrm{C}$ ). ). The reaction time was $60 \mathrm{~min}$ at $37^{\circ} \mathrm{C}$. Relative nucleotide incorporation was defined as the ratio of nucleotide incorporation in the presence of PUM to nucleotide incorporation in the absence of PUM.

\section{Template-sequence specificity of inhibition by PUM: single-nucleotide-addition reactions}

Template-sequence specificity of inhibition by PUM was assessed in single-nucleotide-addition experiments (Fig. 3c) using E. coli RNAP transcription elongation complexes assembled on the following nucleic-acid scaffolds (black, DNA; red, RNA; asterisk, ${ }^{32} \mathrm{P}$ ):

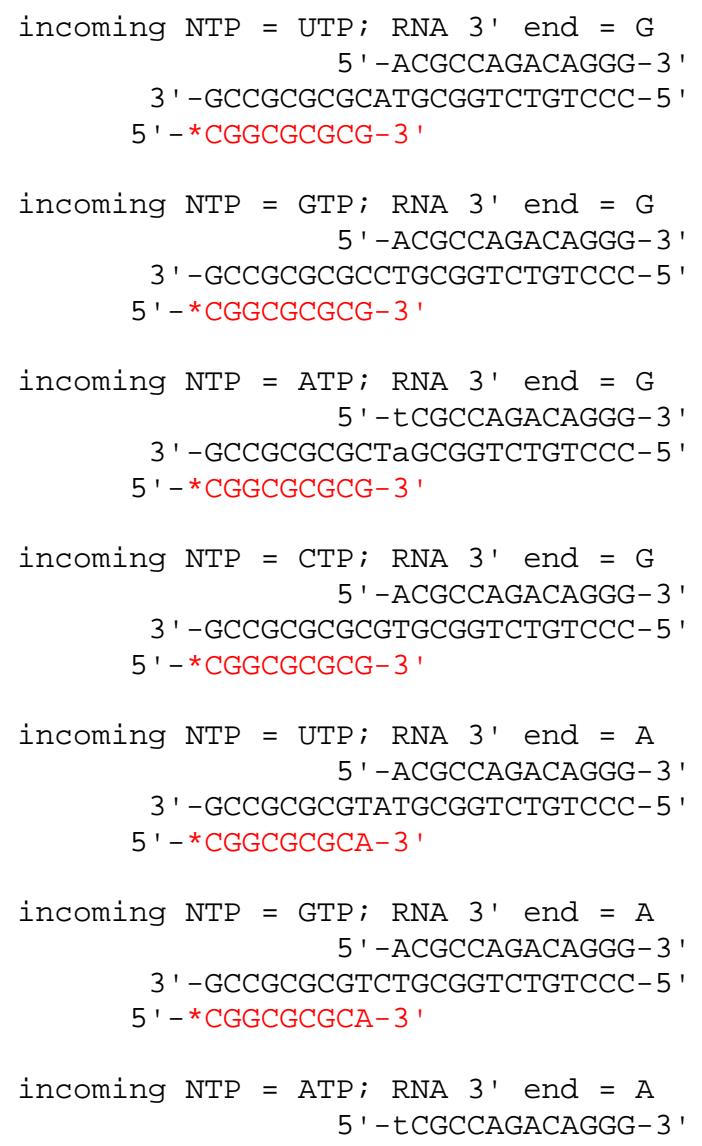




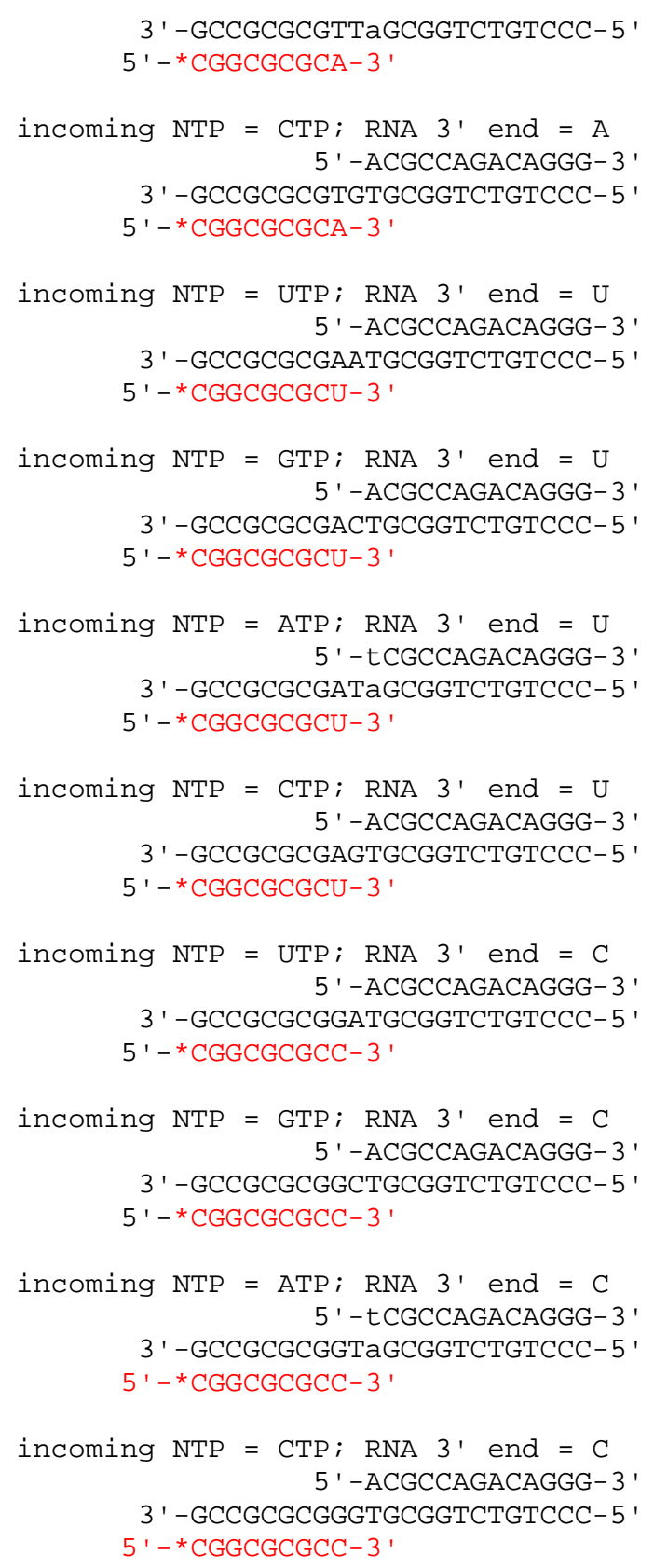

Nucleic-acid scaffolds for single-nucleotide-addition reactions were prepared as follows: $1 \mu \mathrm{M}$ nontemplate-strand oligodeoxyribonucleotide [5'-ACGCCAGACAGGG-3' or 5'-TCGCCAGACAGGG3'; IDT), $1 \mu \mathrm{M}$ template-strand oligodeoxyribonucleotide [5'-GCCGCGCG-(C or T or A or G)-(A or C or G)-TGCGGTCTGTCCC-5' or 5'-GCCGCGCG-(C or T or A or G)-(T)-AGCGGTCTGTCCC-5'; IDT], and $1 \mu \mathrm{M}{ }^{32} \mathrm{P}-5$ '-end-labeled oligoribonuceotide [5'-32 P-CGGCGCGC-(U or C or A or G)-3'; $90 \mathrm{~Bq} / \mathrm{fmol}$; prepared using T4 polynucleotide kinase (New England Biolabs), $\left[\gamma^{32} \mathrm{P}\right] \mathrm{ATP}(100 \mathrm{~Bq} / \mathrm{fmol}$; PerkinElmer), and corresponding unlabelled oligoribonuceotide (IDT); procedures as described $\left.{ }^{37}\right]$, in $5 \mathrm{mM}$ Tris-HCl (pH 7.7), $200 \mathrm{mM} \mathrm{NaCl}$, and $10 \mathrm{mM} \mathrm{MgCl}_{2}$, were heated $5 \mathrm{~min}$ at $95^{\circ} \mathrm{C}$, cooled to $4^{\circ} \mathrm{C}$ in $2^{\circ} \mathrm{C}$ steps with $1 \mathrm{~min} / \mathrm{step}$ using a thermal cycler (Applied Biosystems), and stored at $-20^{\circ} \mathrm{C}$. Reaction mixtures for single-nucleotide-addition reactions contained $(10 \mu \mathrm{l})$ : 0 or $25 \mu \mathrm{M}$ PUM, $40 \mathrm{nM}$ E. coli RNAP core enzyme, $10 \mathrm{nM}$ nucleic-acid scaffold, and $2.5 \mu \mathrm{M}$ ATP, GTP, CTP, or UTP, in $50 \mathrm{mM}$ Tris- $\mathrm{HCl}$ (pH 8.0), 
$100 \mathrm{mM} \mathrm{KCl}, 10 \mathrm{mM} \mathrm{MgCl} 2,1 \mathrm{mM}$ dithiothreitol, $10 \mu \mathrm{g} / \mathrm{ml} \mathrm{BSA}$, and 5\% glycerol. Reaction components except PUM and NTP were pre-incubated 10 min at $37^{\circ} \mathrm{C}$, PUM was added and reaction mixtures were incubated $5 \mathrm{~min}$ at $37^{\circ} \mathrm{C}$, and NTP was added and reaction mixtures were incubated 5 min at $37^{\circ} \mathrm{C}$. Reactions were terminated by addition of $5 \mu 180 \%$ formamide, $10 \mathrm{mM}$ EDTA, $0.04 \%$ bromophenol blue, $0.04 \%$ xylene cyanol, and $0.08 \%$ amaranth red, and heating $2 \mathrm{~min}$ at $95^{\circ} \mathrm{C}$. Samples were applied to denaturing $15 \%$ polyacrylamide (19:1 acrylamide:bisacrylamide, $7 \mathrm{M}$ urea) ${ }^{37}$ slab gels, electrophoresed in $\mathrm{TBE}^{37}$, and analyzed by storage-phosphor scanning (Typhoon 9400; GE Healthcare).

\section{Template-sequence specificity of inhibition by PUM: multiple-nucleotide-addition reactions}

Template-sequence specificity of inhibition by PUM was assessed in multiple-nucleotide-addition experiments (Fig. 3d), performed by adding PUM to transcription elongation complexes halted at position +29 of a 100 bp transcription unit by omission of CTP, re-starting transcription elongation complexes and allowing transcription of positions +30 to +100 of the transcription unit by addition of CTP, and identifying positions at which PUM inhibits transcription.

Halted transcription elongation complexes were prepared as described ${ }^{56}$. Reaction mixtures (20 $\mu$ ) contained: $40 \mathrm{nM}$ E. coli RNAP $\sigma^{70}$ holoenzyme, $10 \mathrm{nM}$ DNA fragment N25-100-tR2 ${ }^{56}, 100 \mu \mathrm{g} / \mathrm{ml}$ heparin, $5 \mu \mathrm{M}\left[\gamma^{32} \mathrm{P}\right] \mathrm{ATP}(6 \mathrm{~Bq} / \mathrm{fmol}$; PerkinElmer), $5 \mu \mathrm{M} \mathrm{UTP}$, and $5 \mu \mathrm{M} \mathrm{GTP}$, in $50 \mathrm{mM}$ Tris- $\mathrm{HCl}(\mathrm{pH}$ 8.0), $100 \mathrm{mM} \mathrm{KCl}, 10 \mathrm{mM} \mathrm{MgCl} 2,1 \mathrm{mM}$ dithiothreitol, $10 \mu \mathrm{g} / \mathrm{ml}$ bovine serum albumin, and $5 \%$ glycerol. Reaction components other than heparin and NTPs were pre-incubated $5 \mathrm{~min}$ at $30^{\circ} \mathrm{C}$; heparin was added and reaction mixtures were incubated $2 \mathrm{~min}$ at $30^{\circ} \mathrm{C}$; NTPs were added and reaction mixtures were incubated $3 \mathrm{~min}$ at $30^{\circ} \mathrm{C}$. Halted transcription elongation complexes were provided with PUM (1.25 $\mu 1125 \mu \mathrm{M}$ PUM, $1.25 \mu \mathrm{l} 250 \mu \mathrm{M}$ PUM, $1.25 \mu \mathrm{l} 500 \mu \mathrm{M}$ PUM, or $1.25 \mu 11 \mathrm{mM}$ PUM) or, to provide markers, chain-terminating 3'-O-methyl-NTPs (RiboMed; $1.25 \mu \mathrm{l} 400 \mu \mathrm{M}$ 3'-O-methyl-UTP, $1.25 \mu 1400$ $\mu \mathrm{M}$ 3'-O-methyl-CTP, $1.25 \mu \mathrm{l} 400 \mu \mathrm{M}$ 3'-O-methyl-GTP, or $1.25 \mu 1400 \mu \mathrm{M}$ 3'-O-methyl-ATP), were incubated $3 \mathrm{~min}$ at $30^{\circ} \mathrm{C}$, were re-started by addition of $0.625 \mu 1200 \mu \mathrm{M} \mathrm{UTP}, 1.25 \mu 1200 \mu \mathrm{M} \mathrm{CTP}$, $0.625 \mu \mathrm{l} 200 \mu \mathrm{M} \mathrm{GTP}$, and $0.625 \mu \mathrm{l} 200 \mu \mathrm{M} \mathrm{ATP}$, and were further incubated $10 \mathrm{~min}$ at $30^{\circ} \mathrm{C}$. Reactions were terminated by addition of $12.5 \mu 180 \%$ formamide, $10 \mathrm{mM}$ EDTA, $0.04 \%$ bromophenol blue, $0.04 \%$ xylene cyanol, and $0.08 \%$ amaranth red, and heating $4 \mathrm{~min}$ at $95^{\circ} \mathrm{C}$. Samples were applied to $10 \%$ polyacrylamide (19:1 acrylamide:bisacrylamide; $7 \mathrm{M}$ urea $)^{37}$ slab gels, electrophoresed in $\mathrm{TBE}^{37}$, and analyzed by storage-phosphor scanning (Typhoon 9400).

\section{Structure determination: RPo-GpA-PUM}

Crystals of T. thermophilus RPo-GpA were prepared as described ${ }^{26}$. Crystallization drops contained $1 \mu \mathrm{l} 18 \mu \mathrm{M}$ RPo (prepared from $T$. thermophilus RNAP $\sigma^{\mathrm{A}}$ holoenzyme and synthetic nucleic-

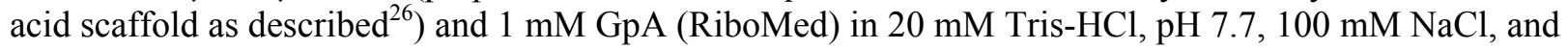
$1 \%$ glycerol, and $1 \mu \mathrm{l}$ reservoir buffer (RB; $100 \mathrm{mM}$ Tris- $\mathrm{HCl}, \mathrm{pH} 8.4,200 \mathrm{mM} \mathrm{KCl}, 50 \mathrm{mM} \mathrm{MgCl}{ }_{2}$, and $10 \%$ PEG4000), and were equilibrated against $400 \mu \mathrm{RB}$ in a vapor-diffusion hanging-drop tray (Hampton Research). Rod-like crystals appeared in 1 day, and grew to a final size of $0.1 \mathrm{~mm} \times 0.1 \mathrm{~mm} \times$ $0.3 \mathrm{~mm}$ in 5 days.

PUM was soaked into RPo-GpA crystals by adding $0.2 \mu 100 \mathrm{mM}$ PUM in RB to the crystallization drop and incubating $30 \mathrm{~min}$ at $22^{\circ} \mathrm{C}$. RPo-GpA-PUM crystals were transferred to reservoir solutions containing $2 \mathrm{mM}$ PUM in $17.5 \%$ (v/v) (2R,3R)-(-)-2,3-butanediol (Sigma-Aldrich) and were flash-cooled with liquid nitrogen.

Diffraction data for RPo-GpA-PUM were collected from cryo-cooled crystals at Cornell High Energy Synchrotron Source (CHESS) beamline F1. Data were integrated and scaled using HKL2000 ${ }^{57}$. Structure factors were converted using the French-Wilson algorithm in Phenix ${ }^{58}$ and were subjected to anisotropy correction using the UCLA MBI Diffraction Anisotropy server (http://services.mbi.ucla.edu/anisoscale/) ${ }^{59}$.

The structure of RPo-GpA-PUM was solved by molecular replacement in Molrep ${ }^{60}$, using one RNAP molecule from the structure of $T$. thermophilus RPo $\left(\mathrm{PDB} 4 \mathrm{G}_{7} \mathrm{H}^{26}\right.$ ) as the search model. 
Early-stage refinement included rigid-body refinement of each RNAP molecule, followed by rigid-body refinement of each subunit of each RNAP molecule. Cycles of iterative model building with $\operatorname{Coot}^{61}$ and refinement with Phenix ${ }^{62}$ were performed. Atomic models of the DNA nontemplate strand, the DNA template strand, and GpA were built into $\mathrm{mFo}-\mathrm{DFc}$ omit maps, and further refinement with Phenix was performed. The atomic model of PUM was built into the mFo-DFc omit map and was refined with Phenix. The final crystallographic model of RPo-GpA-PUM at $3.30 \AA$ resolution, refined to Rwork and Rfree of 0.232 and 0.280, has been deposited in the PDB with accession code 5X21 (Fig. 4a; Extended Data Table 3).

\section{Structure determination: RPo-GpA-CMPcPP}

Crystals of T. thermophilus RPo-GpA-CMPcPP were prepared by co-crystallization.

Crystallization drops contained $1 \mu 18 \mu \mathrm{M}$ RPo (prepared from T. thermophilus RNAP $\sigma^{\mathrm{A}}$ holoenzyme and synthetic nucleic-acid scaffold as described ${ }^{26}$ ), 1 mM GpA (RiboMed), and $10 \mathrm{mM} \mathrm{CMPcPP}$ (Jena Bioscience) in $20 \mathrm{mM}$ Tris- $\mathrm{HCl}, \mathrm{pH} 7.7,100 \mathrm{mM} \mathrm{NaCl}$, and $1 \%$ glycerol, and $1 \mu \mathrm{RB}$, and were equilibrated against $400 \mu \mathrm{RB}$ in a vapor-diffusion hanging-drop tray (Hampton Research). Rod-like crystals appeared in 1 day, and grew to a final size of $0.1 \mathrm{~mm} \times 0.1 \mathrm{~mm} \times 0.3 \mathrm{~mm}$ in 5 days. RPo-GpACMPcPP crystals were transferred to reservoir solutions containing $2 \mathrm{mM} \mathrm{CMPcPP}$ in $17.5 \%(\mathrm{v} / \mathrm{v})$ (2R,3R)-(-)-2,3-butanediol (Sigma-Aldrich), and were flash-cooled with liquid nitrogen.

Diffraction data for RPo-GpA-CMPcPP were collected from cryo-cooled crystals at CHESS beamline F1. Data were integrated and scaled, structure factors were converted and subjected to anisotropy correction, and the structure was solved and refined using procedures analogous to those in the preceding section. The final crystallographic model of RPo-GpA-CMPcPP at $3.35 \AA$ resolution, refined to Rwork and Rfree of 0.208 and 0.250 , has been deposited in the PDB with accession code 5 X22 (Fig. 4b; Extended Data Table 3).

\section{Semi-synthesis of PUM derivatives}

Semi-syntheses of PUM derivatives from PUM corroborate the inferred structure of PUM, provide routes for preparation of novel PUM derivatives, and provide initial structure-activity relationships (Extended Data Fig. 7a,c-d). Reactions were conducted starting from $1 \mathrm{mg}$ PUM, and products were identified by LC-MS (Agilent 1100 with flow split in 1:1 ratio between UV detector and ion-trap ESI-MS interface of Bruker Esquire 3000 Plus; Waters Atlantis $3 \mu \mathrm{m}, 50$ x $4.6 \mathrm{~mm}$, column; phase $\mathrm{A}=0.05 \%$ trifluoroacetic acid in water; phase $\mathrm{B}=$ acetonitrile; gradient $=5-95 \% \mathrm{~B}$ in $6 \mathrm{~min}$; flow rate $=1 \mathrm{ml} / \mathrm{min}$; run temperature $=40^{\circ} \mathrm{C} ; \mathrm{PUM}$ retention time $\left.=1.4 \mathrm{~min}\right)$.

Reaction of PUM with $\mathrm{TiCl}_{3}$ in $1 \mathrm{M}$ sodium acetate $(\mathrm{pH} 7.0)$ for $2 \mathrm{~h}$ at room temperature resulted in reduction of the N-hydroxy moiety, yielding desoxy-PUM $\left(1 ; m / z=471[\mathrm{M}+\mathrm{H}]^{+}\right)$. Reaction of PUM with $\mathrm{PdCl}_{2}{ }^{63}$ in 1:1 acetonitrile:water for $2 \mathrm{~h}$ at room temperature resulted in selective dehydration of the PUM glutamine sidechain amide -NH2, yielding nitrile analog $2\left(\mathrm{~m} / \mathrm{z}=469[\mathrm{M}+\mathrm{H}]^{+}\right)$. Reaction of PUM with $0.1 \%$ TFA in water for 3 days at room temperature resulted in hydrolysis of the glutamine sidechain amide, yielding carboxy analog $3\left(\mathrm{~m} / \mathrm{z}=488[\mathrm{M}+\mathrm{H}]^{+}\right)$. Reaction of 3 with benzylamine in DMF containing benzotriazol-1-yl-oxytripyrrolidinophosphonium hexafluorophosphate (PyBOP) for $30 \mathrm{~min}$ at room temperature yielded benzylamide analog $4\left(\mathrm{~m} / \mathrm{z}=577[\mathrm{M}+\mathrm{H}]^{+}\right)$. Reaction of PUM with 2,3butanedione $^{64}$ in $10 \mathrm{mM}$ ammonium acetate $(\mathrm{pH}$ 8.0) for $30 \mathrm{~min}$ at room temperature resulted in diolic intermediate $5\left(\mathrm{~m} / \mathrm{z}=573[\mathrm{M}+\mathrm{H}]^{+}\right)$, which subsequently was trapped by treatment with phenylboronic acid for $2 \mathrm{~h}$ at room temperature, yielding phenyl-dioxaborolan analog $6\left(\mathrm{~m} / \mathrm{z}=659[\mathrm{M}+\mathrm{H}]^{+}\right)$.

\section{Total synthesis of desoxy-PUM}

Total synthesis of desoxy-PUM provides a reference compound that corroborates the inferred stereochemistry of PUM [by comparison of desoxy-PUM prepared by total synthesis (1 in Extended Data Fig. 7b) to desoxy-PUM prepared by semi-synthesis from PUM (1 in Extended Data Fig. 7a] and provides an additional route to novel PUM derivatives. Desoxy-PUM was obtained in eight steps by 
convergent synthesis from commercially available $\beta$-D-pseudouridine and glycyl-L-glutamine, as follows (Extended data Fig. 7b):

Acetonide protection (reaction a in Extended Data Fig. 7b). To a solution of $\beta$-D-pseudouridine (Berry \& Associates; $400 \mathrm{mg}, 1.64 \mathrm{mmol}$ ) and 2,2-dimethoxypropane (Sigma-Aldrich; $12 \mathrm{ml}$ ) in dimethylformamide $(8 \mathrm{ml})$, concentrated $\mathrm{HCl}(80 \mu \mathrm{L})$ was added, and the reaction mixture was stirred $5 \mathrm{~h}$ at room temperature. After neutralization with $2.5 \mathrm{M} \mathrm{NaOH}$, solvent was removed under vacuum. ${ }^{1} \mathrm{H}-$ NMR (400 MHz, $\left.\mathrm{D}_{2} \mathrm{O}, \delta-\mathrm{H}\right): 1.35\left(\mathrm{~s}, 3 \mathrm{H}, \mathrm{CH}_{3}\right), 1.56\left(\mathrm{~s}, 3 \mathrm{H}, \mathrm{CH}_{3}\right), 3.67$ (dd, 1H, J = 12.2, $5.65 \mathrm{~Hz}, \mathrm{H}-5$ '), 3.75 (dd, 1H, J = 12.2, 3.75 Hz, H-5'), 4.11 (dd, 1H, H-4'), 4.75 (m, 2H), 4.86 (m, 1H), 7.62 (s, 1H, H-6).

Mesylation (reaction b in Extended Data Fig. 7b). To a solution of the crude product of the preceding step (419 mg, $1.47 \mathrm{mmol}$ ) in pyridine (Sigma-Aldrich; $4.7 \mathrm{ml}$ ), methanesulfonyl chloride (Sigma-Aldrich: $95 \mu \mathrm{L}, 1.23 \mathrm{mmol}$ ) was added with stirring at $0^{\circ} \mathrm{C}$. The reaction mixture was stirred at room temperature until completeness $(16 \mathrm{~h})$. Solvent was removed by rotary evaporation, and the raw material was purified by flash chromatography on Combiflash (Teledyne ISCO), yielding $475 \mathrm{mg}$ of a white powder (95\% yield). ${ }^{1} \mathrm{H}-\mathrm{NMR}\left(400 \mathrm{MHz}\right.$, acetonitrile- $\left.\mathrm{d}_{3}, \delta-\mathrm{H}\right): 1.32\left(\mathrm{~s}, 3 \mathrm{H}, \mathrm{CH}_{3}\right), 1.54(\mathrm{~s}, 3 \mathrm{H}$, $\left.\mathrm{CH}_{3}\right), 4.33\left(\mathrm{dd}, 1 \mathrm{H}, \mathrm{J}=11 \mathrm{~Hz}, \mathrm{H}-5^{\prime}\right), 4.46\left(\mathrm{dd}, 1 \mathrm{H}, \mathrm{J}=11 \mathrm{~Hz}, \mathrm{H}-5^{\prime}\right), 4.20$ (m, 1H), 4.72 (dd, 1H), 4.80 (m, 2H), 7.55 (s, 1H, H-6), 10.23 (sb, 1H, NH), 10.45 (sb, 1H, NH).

Azidation (reaction c in Extended Data Fig. 7b). To a solution of the product of the preceding step $(475 \mathrm{mg})$ in dimethylformamide $(24 \mathrm{ml})$, sodium azide (Sigma-Aldrich: $476 \mathrm{mg}$ ) was added, the reaction mixture was stirred $4 \mathrm{~h}$ at $100^{\circ} \mathrm{C}$, and solvent was removed by rotary evaporation. ${ }^{1} \mathrm{H}-\mathrm{NMR}$ (400 $\mathrm{MHz}$, acetonitrile- $\left.\mathrm{d}_{3}, \delta-\mathrm{H}\right): 1.30\left(\mathrm{~s}, 3 \mathrm{H}, \mathrm{CH}_{3}\right), 1.50\left(\mathrm{~s}, 3 \mathrm{H}, \mathrm{CH}_{3}\right), 3.52(\mathrm{~d}, 2 \mathrm{H}, \mathrm{J}=5.3 \mathrm{~Hz}, \mathrm{H}-5$ '), $4.04(\mathrm{~m}$, 1H, H-3'), 4.69 (dd, 1H, H-4'), 4.75 (d, 1H, J = 3.3 Hz, H-1'), 4.87 (dd, 1H, J = 3.3 Hz, H-2'), 7.58 (s, 1H, H-6).

Azide reduction (reaction d in Extended Data Fig. 7b). To a solution of the crude product of the preceding step $(193 \mathrm{mg})$ in tetrahydrofuran $(8.8 \mathrm{ml})$ and water $(1.8 \mathrm{ml}), 1 \mathrm{M}$ trimethylphosphine in tetrahydrofuran (Sigma-Aldrich; $0.74 \mathrm{ml}$ ) was added, the reaction mixture was stirred $2 \mathrm{~h}$ at room temperature, and solvent was removed by rotary evaporation. ${ }^{1} \mathrm{H}-\mathrm{NMR}\left(400 \mathrm{MHz}, \mathrm{D}_{2} \mathrm{O}, \delta-\mathrm{H}\right): 1.47$ (s, $\left.3 \mathrm{H}, \mathrm{CH}_{3}\right), 168\left(\mathrm{~s}, 3 \mathrm{H}, \mathrm{CH}_{3}\right), 3.40$ (dd, 1H, H-5'), 3.49 (dd, 1H, H-5'), 4.38 (m, 1H, H-4'), 4.90 (dd, 1H, H1'), 4.94 (d, 1H, H-3'), 5.05 (dd, 1H, H-2'), 7.76 (s, 1H, H-6).

Fmoc protection (reaction e in Extended Data Fig. 7b). To a solution of the crude product of the preceding step $(22 \mathrm{mg}, 0.11 \mathrm{mmol})$ in dioxane $(150 \mu \mathrm{L})$ and water $(250 \mu \mathrm{L})$ sodium carbonate $(26.5 \mathrm{mg})$ was added, followed by Fmoc chloride (Sigma-Aldrich; $31 \mathrm{mg}, 1.3 \mathrm{eq}$ ), and the reaction mixture stirred overnight at room temperature. After addition of water $(5 \mathrm{ml})$, the reaction was extracted with ethyl acetate $(3 \times 5 \mathrm{ml})$, the combined organic extracts were extracted with saturated sodium bicarbonate $(3 \times 5$ $\mathrm{ml}$ ), the combined aqueous extracts were acidified to $\mathrm{pH} 1$ with $1 \mathrm{M} \mathrm{HCl}$ and extracted with ethyl acetate $(3 \times 5 \mathrm{ml})$, and the combined organic extracts were treated with sodium sulfate and evaporated to dryness, providing Fmoc-glycl-L-glutamine in quantitative yield. ${ }^{1} \mathrm{H}-\mathrm{NMR}\left(400 \mathrm{MHz}, \mathrm{D}_{2} \mathrm{O}, \delta-\mathrm{H}\right): 1.98(\mathrm{~m}, 1 \mathrm{H}$, Asn- $\beta$ ), 2.18 (m, 1H, Asn- $\beta$ ), 2.33 (m, 2H, Asn- $\gamma), 3.90$ (m, 2H, Gly- $\alpha), 4.23$ (m, 1H), 4.31 (m, 1H), 4.47 (dd, 1H, Asn- $\alpha$ ), 7.31 (m, 2H, Ar), 7.38 (m, 2H, Ar), 7.69 (m, 2H, Ar), 7.81 (m, 2H, Ar).

Coupling, Fmoc deprotection, and formamidinylation (reactions f-h in Extended Data Fig. 7b). To a solution of the product of the preceding step $(20 \mathrm{mg})$ and the product of the azide-reduction reaction (30 $\mathrm{mg}, 1.1 \mathrm{eq})$ in dry dimethylformamide $(1.5 \mathrm{ml}), \mathrm{N}, \mathrm{N}^{\prime}$-dicyclohexylcarbodiimide (Sigma-Aldrich; $18 \mathrm{mg}$, $1.2 \mathrm{eq}$ ) and 1-hydroxybenzotriazole (Sigma-Aldrich; $19.5 \mathrm{mg}, 2 \mathrm{eq}$ ) were added, and the reaction mixture was stirred overnight at room temperature, and the solvent was evaporated under reduced pressure. To a solution of the crude coupled product $(12 \mathrm{mg})$ in dimethylformamide $(800 \mu \mathrm{l})$, piperidine $(200 \mu \mathrm{l})$ was added, and the reaction mixture was stirred $10 \mathrm{~min}$ at $25^{\circ} \mathrm{C}$, the solvent was evaporated under reduced pressure, and the residue was washed with methylene chloride $(2 \times 5 \mathrm{ml})$. To a solution of the crude Fmoc-deprotected product (22 mg) in methanol (300 $\mu$ l), 3,5-dimethylpyrazole-1-carboxamidine (SigmaAldrich; $45 \mathrm{mg}, 10 \mathrm{eq}$ ) was added, and the reaction mixture was stirred overnight at room temperature, followed by $6 \mathrm{~h}$ under reflux at $65^{\circ} \mathrm{C}$ to complete the reaction. The solvent was evaporated under reduced pressure, and the solid residue was washed with methylene chloride $(2 \times 10 \mathrm{ml}) .{ }^{1} \mathrm{H}-\mathrm{NMR}(400 \mathrm{MHz}$, 
$\left.\mathrm{D}_{2} \mathrm{O} / \mathrm{CD}_{3} \mathrm{OD}, \delta-\mathrm{H}\right): 1.33$ (s, 3H, $\left.\mathrm{CH}_{3}\right), 1.54$ (s, 3H, $\left.\mathrm{CH}_{3}\right), 2.01$ (m, 1H, Asn- $\beta$ ), 2.17 (m, $1 \mathrm{H}$, Asn- $\beta$ ), 2.37 (m, 2H, Asn- $\gamma), 3.37$ (m, 1H, H-5'), 3.65 (m, 1H, H-5'), 4.04 (s, 2H, Gly- $\alpha), 4.03(\mathrm{~m}, 1 \mathrm{H}), 4.11(\mathrm{~m}, 1 \mathrm{H})$, $4.42(\mathrm{~m}, 1 \mathrm{H}), 4.63(\mathrm{~m}, 1 \mathrm{H}), 7.53$ (s, 1H, H-6).

Acetonide deprotection (reaction i in Extended Data Fig. 7b). A solution of the crude product of the preceding step $(17 \mathrm{mg})$ in acetic acid:water $(7: 3 ; 2 \mathrm{ml})$ was stirred overnight at room temperature and then heated to $50^{\circ} \mathrm{C}$ for $10 \mathrm{~h}$ under argon. The solvent was evaporated under reduced pressure, and the solid residue was washed with methylene chloride $(2 \times 5 \mathrm{ml})$ and methanol $(2 \mathrm{ml})$, yielding a white solid that, when analyzed by LC-MS [performed as described for LC-MS of PUM (Methods, Structure Elucidation of PUM); retention time $=14 \mathrm{~min}], 1 \mathrm{D}$ - and 2D-NMR, was indistinguishable from desoxyPUM obtained by reduction of PUM with $\mathrm{TiCl}_{3}\left(\mathbf{1}\right.$ in Extended Data Fig. 7a). ${ }^{1} \mathrm{H}-\mathrm{NMR}(600 \mathrm{MHz}$, DMSO-d $\left._{6} / \mathrm{D}_{2} \mathrm{O}, \delta-\mathrm{H}\right): 1.75$ (m, 1H, Asn- $\beta$ ), 1.90 (m, 1H, Asn- $\beta$ ), 2.10 (m, 2H, Asn- $\gamma$ ), 3.29 (m, 2H, H$\left.5^{\prime}\right), 3.72(\mathrm{~m}, 2 \mathrm{H}), 3.87$ (s broad, $\left.2 \mathrm{H}, \mathrm{Gly}-\alpha\right), 3.96$ (m, 1H, H-2'), 4.24 (m, 1H, Asn- $\alpha$ ), 4.40 (d, 1H, J=5.3 $\mathrm{Hz}, \mathrm{H}-1$ '), 6.73 (s broad, $\mathrm{CONH}_{2}$ ), 7.32 (s broad, $\mathrm{CONH}_{2}$ ), 7.40 (s, 1H), 8.11 (t broad, 1H, NH), 8.34 (d broad, $1 \mathrm{H}, \mathrm{NH}-\mathrm{Asn}$ ). ${ }^{13} \mathrm{C}-\mathrm{NMR}$ (DMSO-d ${ }_{6}, \delta$-H): 28.4, 31.9, 41.4, 44.0, 53.0, 72.3, 73.7, 79.9, 81.6, $110.4,141.5,152.2,158.2,164.2,168.0,171.3,173.7$.

\section{Data analysis}

Data for RNAP-inhibitory activities, growth-inhibitory activities, resistance, and cross-resistance are means of at least two technical replicates. Data for mouse infection models, resistance-rate assays, and checkerboard interaction assays are means and 95\% confidence intervals for eight biological replicates, at least six biological replicates, and at least five technical replicates, respectively.

\section{Data availability}

Atomic coordinates and structure factors for crystal structures of RPo-GpA-PUM and RPo-GpA-CMPcPP have been deposited in the Protein Data Bank with accession numbers $5 \mathrm{X} 21$ and 5X22. 16S rRNA gene sequences of PUM producer strains ID38640 and ID38673 have been deposited in GenBank with accession numbers JQ929050 and JQ929051. 


\section{REFERENCES}

24. Hudson, B., Quispe, J., Lara-González, S., Kim, Y., Berman, H., Arnold, E., Ebright, R. \& Lawson, C. Three-dimensional EM structure of an intact activator-dependent transcription initiation complex. Proc. Natl. Acad. Sci. USA 106, 19830-19835 (2009).

25. Vrentas, C., Gaal, T., Ross, W., Ebright, R. \& Gourse, R. Response of RNA polymerase to ppGpp: requirement for the $\omega$ subunit and relief of this requirement by DksA. Genes Dev. 19, 2378-2387 (2005).

26. Zhang, Y., Feng, Y., Chatterjee, S., Tuske, S., Ho, M., Arnold, E. \& Ebright, R. H. Structural basis of transcription initiation. Science 338, 1076-1080 (2012).

27. Tang, H., Severinov, K., Goldfarb, A., Fenyo, D., Chait, B. \& Ebright, R. Location, structure, and function of the target of a transcription activator protein. Genes Dev. 8, 3058-3067 (1994).

28. Severinov, K., Mooney, R., Darst, S. A. \& Landick, R. Tethering of the large subunits of Escherichia coli RNA polymerase. J. Biol. Chem. 272, 24137-24140 (1997).

29. Niu, W., Kim, Y., Tau, G., Heyduk, T. \& Ebright, R. Transcription activation at Class II CAPdependent promoters: two interactions between CAP and RNA polymerase. Cell 87, 1123-1134 (1996).

30. Qi, Y. \& Hulett, F. M. PhoP P and RNA polymerase $\sigma^{A}$ holoenzyme are sufficient for transcription of Pho regulon promoters in Bacillus subtilis: PhoP P activator sites within the coding region stimulate transcription in vitro. Mol. Microbiol. 28 (1998).

31. Donadio, S., Monciardini, P. \& Sosio, M. Approaches to discovering novel antibacterial and antifungal agents. Meths. Enzymol. 458, 3-28 (2009).

32. Mazza, P., Monciardini, P., Cavaletti, L., Sosio, M. \& Donadio, S. Diversity of Actinoplanes and related genera isolated from an Italian soil. Microb. Ecol. 45, 362-372 (2003).

33. Ploeser, J. \& Loring, H. The ultraviolet absorption spectra of the pyrimidine ribonucleosides and ribonucleotides. J. Biol. Chem. 178, 431-437 (1949).

34. Mattingly, P. \& Miller, M. Titanium trichloride reduction of substituted N-hydroxy-2azetidinones and other hydroxamic acids. J. Org. Chem. 45, 410-411 (1980).

35. Kettenring J., Colombo, L., Ferrari, P., Tavecchia, P., Nebuloni, M., Vékey, K., Gallo, G. \& Selva, E. Antibiotic GE2270A: a novel inhibitor of bacterial protein synthesis: I. structure elucidation. J. Antibiot. 44, $702-715$ (1991).

36. Sancar, A., Stachelejk, C., Konigsberg, W. \& Rupp, Sequences of the recA gene and protein. Proc. Natl. Acad. Sci. USA 77, 2611-2615 (1980).

37. Sambrook, J. \& Russell, D. Molecular Cloning: A Laboratory Manual (Cold Spring Harbor Laboratory, Cold Spring Harbor, NY, 2001).

38. Schreiber, E., Matthias, P., Müller, M. \& Schaffner, W. Rapid detection of octamer binding proteins with 'mini-extracts', prepared from a small number of cells. Nucl. Acids Res. 17, 6419 (1989).

39. Pfleiderer, C., Smid, A., Bartsch, I. \& Grummt I. An undecamer DNA sequence directs termination of human ribosomal gene transcription. Nucl. Acids Res. 18, 4727-4736 (1990).

40. Dean, N. \& Berk, A. (1988) Ordering promoter binding of class III transcription factors TFIIIC1 and TFIIIC2. Mol. Cell. Biol. 8, 3017-3025.

41. Holowachuk, S., Bal'a, M. \& Buddington, R. A kinetic microplate method for quantifying the antibacterial properties of biological fluids. J. Microbiol. Meth. 55, 441-446 (2003).

42. Clinical and Laboratory Standards Institute (CLSI/NCCLS). Methods for Dilution Antimicrobial Susceptibility Tests for Bacteria that Grow Aerobically; Approved Standard, Eighth Edition. CLIS Document M07-A8. Wayne, PA. (2009).

43. Barry, A., Pfaller, M. \& Fuchs, P. Haemophilus test medium versus Mueller-Hinton broth with lysed horse blood for antimicrobial susceptibility testing of four bacterial species. Eur. J. Clin. Microbiol. Infect. Dis. 12, 548-553 (1993). 
44. Mazzetti, C., Ornaghi, M., Gaspari, E., Parapini, S., Maffioli, S., Sosio, M. \& Donadio, S. Halogenated spirotetronates from Actinoallomurus. J. Nat. Prod. 75 (2012).

45. Hamilton, M., Russo, R. \& Thurston, R. Trimmed Spearman-Karber method for estimating median lethal concentrations in toxicity bioassays. Environ. Sci. Technol. 11, 714-719 (1977).

46. White, R., Manduru, M. \& Bosso, J. Comparison of three different in vitro methods of detecting synergy: time-kill, checkerboard, and E test. Antimicrob. Agents Chemother. 40, 1914-1918 (1996).

47. Meletiadis, J., Pournaras, S., Roilides, E. \& Walsh, T. Defining fractional inhibitory concentration index cutoffs for additive interactions based on self-drug additive combinations, Monte Carlo simulation analysis, and in vitro-in vivo correlation data for antifungal drug combinations against Aspergillus fumigatus. Antimicrob. Agents Chemother. 54, 602-609. (2010).

48. Srivastava, A., Degen, D., Ebright, Y. \& Ebright, R. Frequency, spectrum, and nonzero fitness costs of resistance to myxopyronin in Staphylococcus aureus. Antimicrob. Agents Chemother. 56, 6250-6255 (2012).

49. Ma, W., Sandri, G. \& Sarkar, S. Analysis of the Luria-Delbrück distribution using discrete convolution powers. J. Appl. Probab. 29, 255-267 (1992).

50. Sarkar, S., Ma, W. \& Sandri, G. On fluctuation analysis: a new, simple and efficient method for computing the expected number of mutants. Genetica 85, 173-179 (1992).

51. Hall, B., Ma, C., Liang, P. \& Singh, K. 2009. Fluctuation Analysis CalculatOR: a web tool for the determination of mutation rate using Luria-Delbrück fluctuation analysis. Bioinformatics 25, 1564-1565 (2009).

52. Fralick, J. \& Burns-Keliher, L. Additive effect of tolC and rfa mutations on the hydrophobic barrier of the outer membrane of Escherichia coli K-12. J. Bacteriol. 176, 6404-6406 (1994).

53. Ebright, R. \& Ebright, Y. Antibacterial agents: high-potency myxopyronin derivatives. WO/2012037508 (2013).

54. Ciciliato, I., Corti, E., Sarubbi, E., Stefanelli, S., Gastaldo, L., Montanini, N., Kurz, M., Losi, D., Marinelli, F. \& Selva, E. Antibiotics GE23077, novel inhibitors of bacterial RNA polymerase I. taxonomy, isolation and characterization. J. Antibiot. 57, 210-217 (2004).

55. Wang, D., Meier, T., Chan, C., Feng, G., Lee, D. \& Landick, R. Discontinuous movements of DNA and RNA in RNA polymerase accompany formation of a paused transcription complex. Cell 81, 341-350 (1995).

56. Revyakin, A., Liu, C., Ebright, R. \& Strick, T. Abortive initiation and productive initiation by RNA polymerase involve DNA scrunching. Science 314, 1139-1143 (2006).

57. Otwinowski, Z. \& Minor, W. Processing of X-ray diffraction data collected in oscillation mode. Meths. Enzymol. 276, 307-326 (1997).

58. French, S. \& Wilson, K. On the treatment of negative intensity observations. Acta Cryst. D 34, 517-525 (1978).

59. Strong, M., Sawaya, M., Wang, S., Phillips, M., Cascio, D. \& Eisenberg, D. Toward the structural genomics of complexes: crystal structure of a PE/PPE protein complex from Mycobacterium tuberculosis. Proc. Natl. Acad. Sci. USA 103 (2006).

60. Vagin, A. \& Teplyakov, A. MOLREP: an automated program for molecular replacement. J. Appl. Cryst. 30 (1997).

61. Emsley, P., Lohkamp, B., Scott, W. \& Cowtan, K. Features and development of Coot. Acta Cryst. D 66, 486-501 (2010).

62. Adams, P., Afonine, P., Bunkóczi, G., Chen, V., Davis, I., Echols, N., Head, J., Hung, L., Kapral, G., Grosse-Kunstleve, R., McCoy, A., Moriarty, N., Oeffner, R., Read, R., Richardson, D., Richardson, J., Terwilliger, T. \& Zwart, P. PHENIX: a comprehensive Python-based system for macromolecular structure. Acta Cryst. D 66, 213-221 (2010).

63. Maffioli, S., Marzorati, E. \& Marazzi. A. Mild and reversible dehydration of primary amides with $\mathrm{PdCl}_{2}$ in aqueous acetonitrile. Org. Lett. 7, 5237-5239 (2005). 
64. Leitner, A. \& Lindner, W. Probing of arginine residues in peptides and proteins using selective tagging and electrospray ionization mass spectrometry. J. Mass Spectrom. 38, 891-899 (2003).

65. Lancini, G. \& Sartori, G. Rifamycins LXI: in vivo inhibition of RNA synthesis of rifamycins. Experentia 24, 1106-1106 (1968).

66. Lancini, G., Pallanza, R. \& Silvestri, L. Relationships between bactericidal effect and inhibition of ribonucleic acid nucleotidyltransferase by rifampicin in Escherichia coli K-12. J. Bacteriol. 97, 761-768 (1969).

67. Sergio, S., Pirali, G., White, R. \& Parenti, F. Lipiarmycin, a new antibiotic from Actinoplanes III. Mechanism of action. J. Antibiot. 1975, 543-549 (1975).

68. Irschik, H., Gerth, K., Hofle, G., Kohl, W. \& Reichenbach, H. The myxopyronins, new inhibitors of bacterial RNA synthesis from Myxococcus fulvus (Myxobacterales). J. Antibiot. 36, 1651-1658 (1983).

69. Irschik, H., Jansen, R., Hofle, G., Gerth, K. \& Reichenbach, H. The corallopyronins, new inhibitors of bacterial RNA synthesis from Myxobacteria. J. Antibiot. 38, 145-152 (1985).

70. Irschik, H., Augustiniak, H., Gerth, K., Hofle, G. \& Reichenbach, H. The ripostatins, novel inhibitors of eubacterial RNA polymerase isolated from Myxobacteria. J. Antibiot. 48, 787-792 (1995).

71. Weinzierl, R. The nucleotide addition cycle of RNA polymerase is controlled by two molecular hinges in the Bridge Helix domain. BMC Biol. 8, 134 (2010).

72. Hein, P. \& Landick, R. The bridge helix coordinates movements of modules in RNA polymerase. BMC Biol. 8 (2010).

73. Sweetser, D., Nonet, M. \& Young, R. Prokaryotic and eukaryotic RNA polymerases have homologous core subunits. Proc. Natl. Acad. Sci. USA 84, 1192-1196 (1987).

74. Lane, W. \& Darst, S. Molecular evolution of multisubunit RNA polymerases: sequence analysis. J. Mol. Biol. 395, 671-685 (2010).

75. Jokerst, R., Weeks, J., Zehring, W., \& Greenleaf, A. Analysis of the gene encoding the largest subunit of RNA polymerase II in Drosophila. Mol. Gen. Genet. 215, 266-275 (1989). 


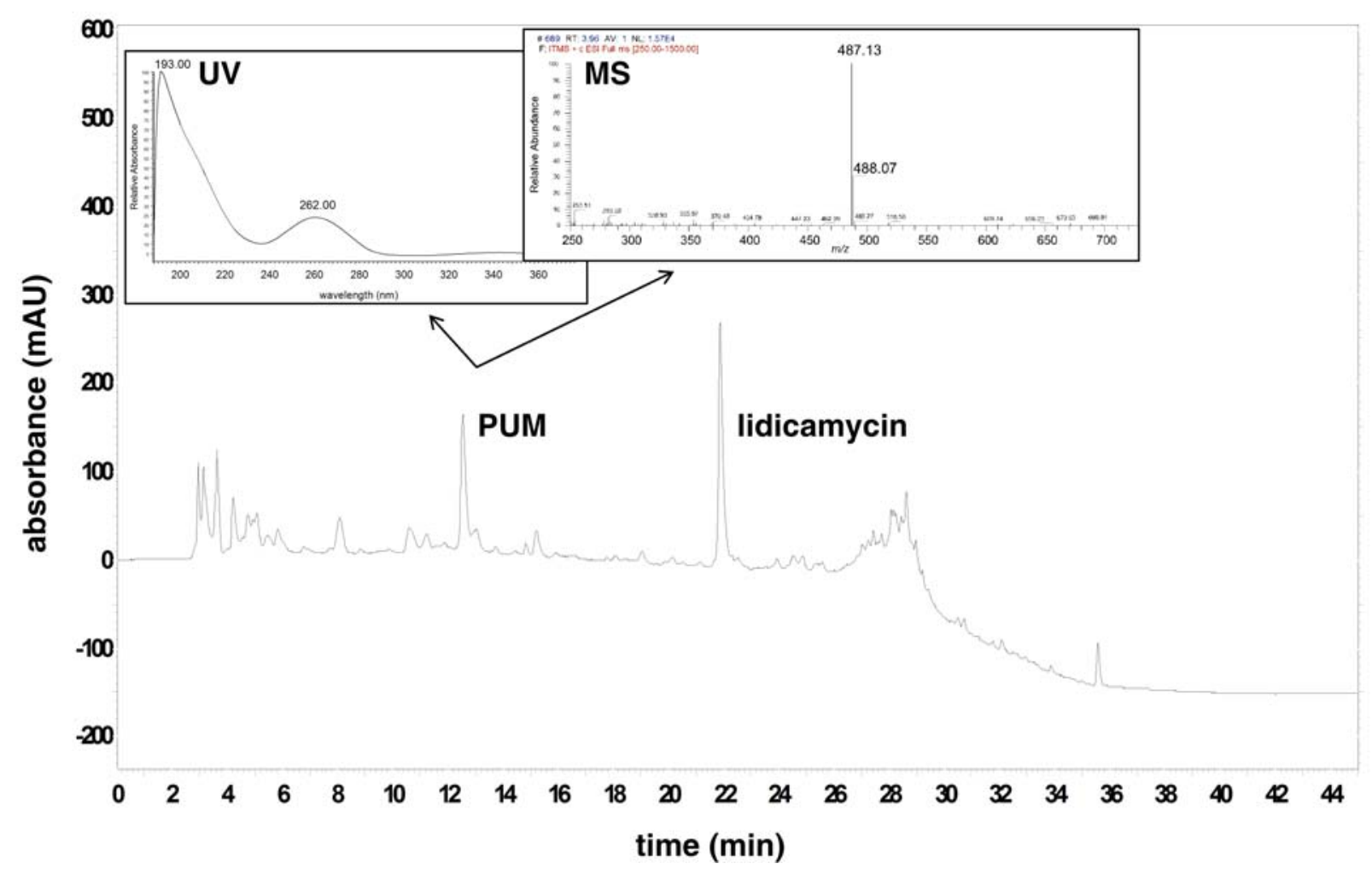

\section{Extended Data Figure 1. Isolation of PUM.}

Chromatographic profile of Streptomyces sp. ID38640 culture extract, showing peaks for PUM and lidicamycin, and UV-absorbance and mass spectra for PUM. 
a
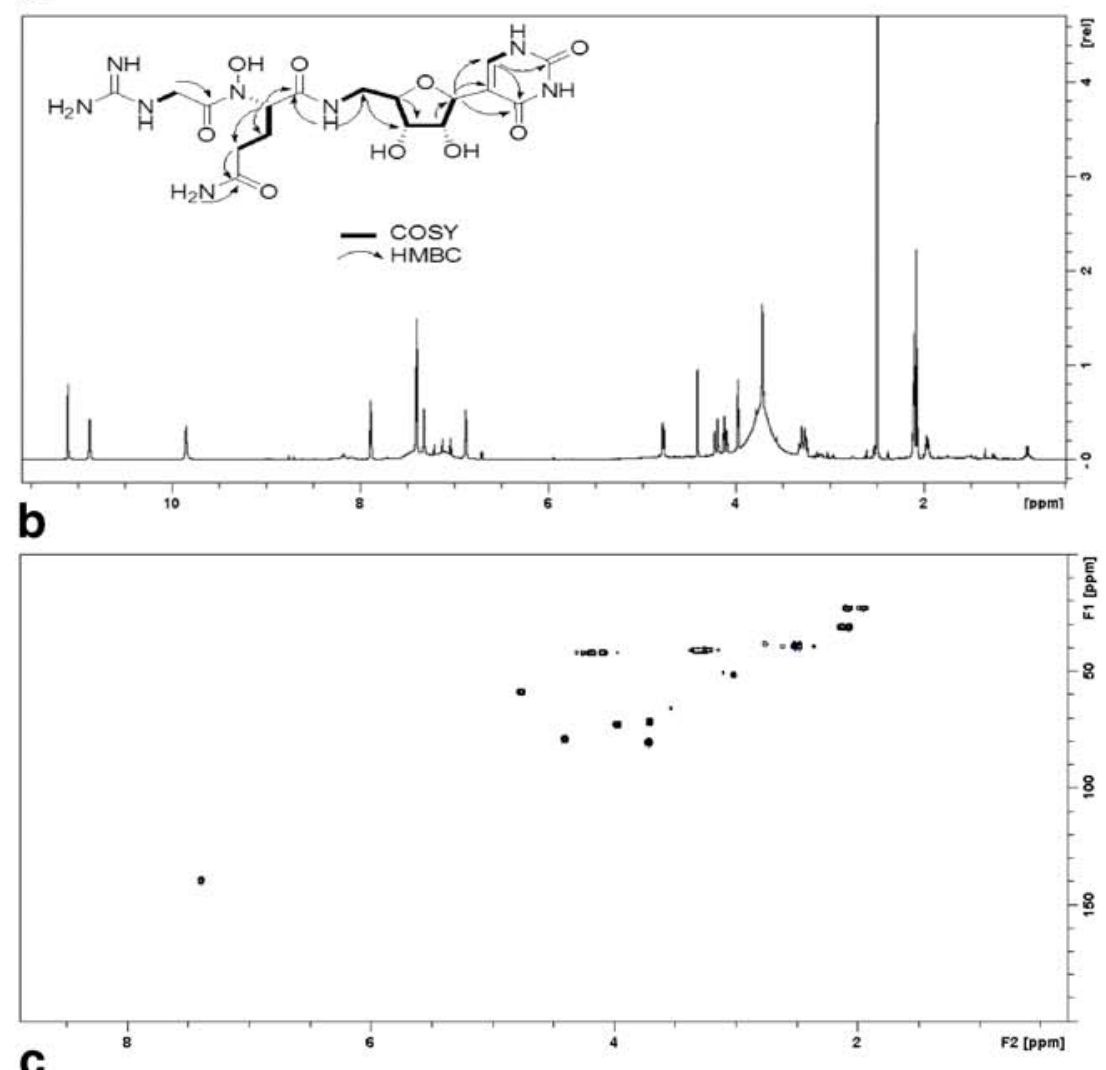

C

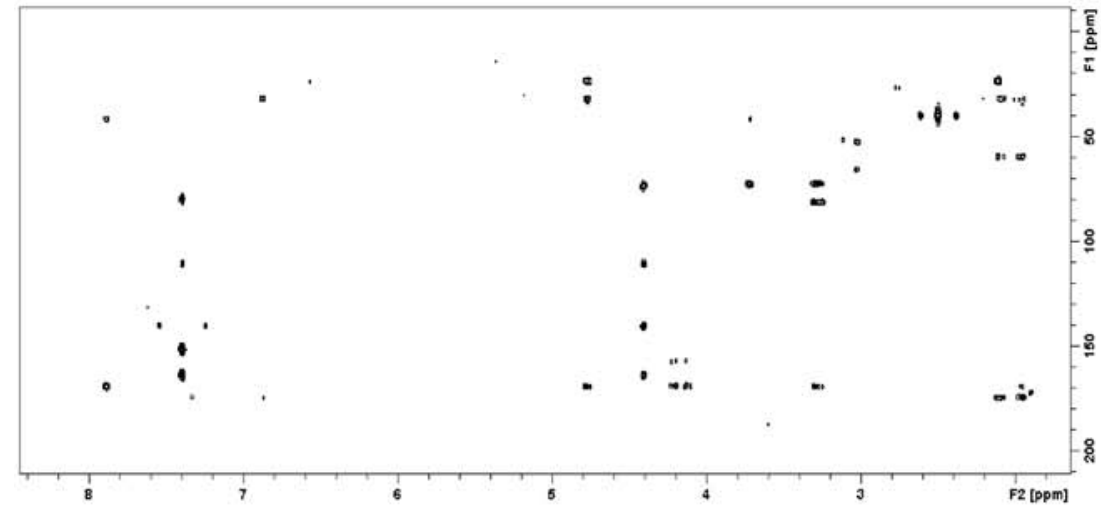

d

${ }^{1} \mathrm{H}-{ }^{13} \mathrm{C}-$, and ${ }^{15} \mathrm{~N}-\mathrm{NMR}$ data of PUM in DMSO-d $\mathrm{d}_{6}$ at $25^{\circ} \mathrm{C}$

\begin{tabular}{|c|c|c|c|c|}
\hline & & 'H ( $\delta$, ppm), multiplicity $(\mathrm{J}[\mathrm{Hz}])$ & ${ }^{13} \mathrm{C}(8, \mathrm{ppm})$ & ${ }^{15} \mathrm{~N}(\delta, \mathrm{ppm})$ \\
\hline \multirow{6}{*}{ ribose } & 1 & $4.34, d(4.70)$ & 79.8 & \\
\hline & 2 & $3.91, \mathrm{dd}(4.70,5.32)$ & 73.8 & \\
\hline & 3 & $3.65, \mathrm{~m}$ & 76.3 & \\
\hline & 4 & $3.65, \mathrm{~m}$ & 81.4 & \\
\hline & $5^{\prime}$ & $3.24, \mathrm{~m} ; 3.14, \mathrm{~m}$ & 42 & \\
\hline & $6^{*}$ & $7.82, t(5.62)$ & & 108.5 \\
\hline \multirow{6}{*}{ pseudouridine } & 1 & & 110.7 & \\
\hline & 2 & & 164 & \\
\hline & 3 & $11.04, d(1.92)$ & & 158.5 \\
\hline & 4 & & 152 & \\
\hline & 5 & $10.8, \mathrm{dd}(1.64)$ & & 131 \\
\hline & 6 & $7.33, d(1.62)$ & 140.4 & \\
\hline \multirow{6}{*}{ Gin } & $\mathrm{C}=\mathrm{O}$ & & 169.5 & \\
\hline & $\alpha$ & $4.72, \mathrm{~m}$ & 59 & \\
\hline & $\beta$ & $2.03, m ; 1.90, m$ & 23.6 & \\
\hline & $\gamma$ & $2.04, m ; 1.91, m$ & 31.7 & \\
\hline & 8 & & 174 & \\
\hline & $\mathrm{NE}$ & 7.26 , bs; 6.81, bs & & 108.9 \\
\hline \multirow{3}{*}{ Gly } & $\mathrm{NH}$ & 7.43, dd $(4.95,5.06)$ & & 75.1 \\
\hline & $\mathrm{C}=0$ & & 157 & \\
\hline & $\alpha$ & $4.22, m ; 4.12, m$ & 43 & \\
\hline
\end{tabular}



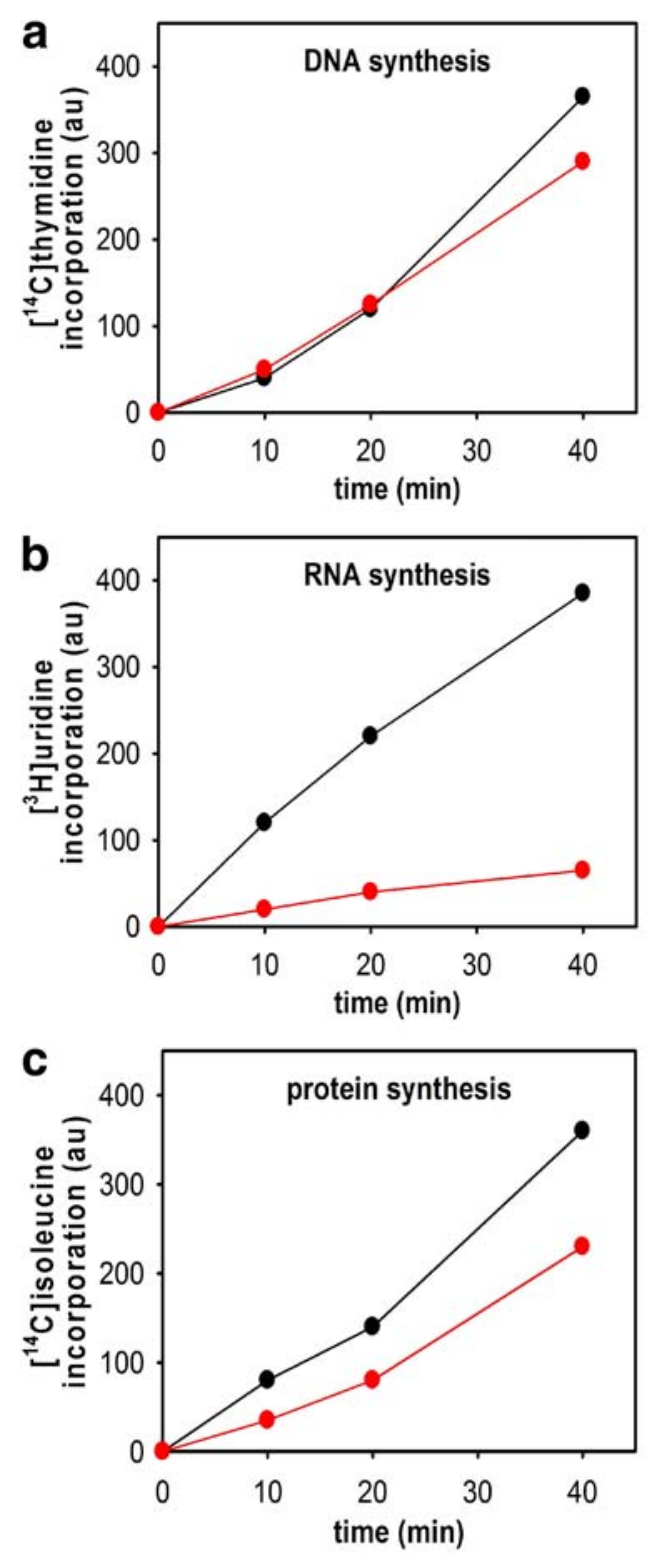

Extended Data Figure 3. Effects of PUM on macromolecular synthesis in bacterial cells in culture: inhibition of RNAP-dependent RNA synthesis.

Effects of PUM on DNA synthesis $\left(\mathbf{a} ;\left[{ }^{14} \mathrm{C}\right]\right.$-thymidine incorporation), RNA synthesis $\left(\mathbf{b} ;\left[{ }^{3} \mathrm{H}\right]\right.$-uridine incorporation), and protein synthesis $\left(\mathbf{c} ;\left[{ }^{14} \mathrm{C}\right]\right.$-isoleucine incorporation) in Staphylococcus simulans in culture. Results match characteristic pattern for inhibition of RNAP-dependent RNA-synthesis ${ }^{18,65-70}$ : i.e., rapid and strong inhibition of RNA synthesis, slower and weaker inhibition of protein synthesis, and little or no inhibition of DNA synthesis. 


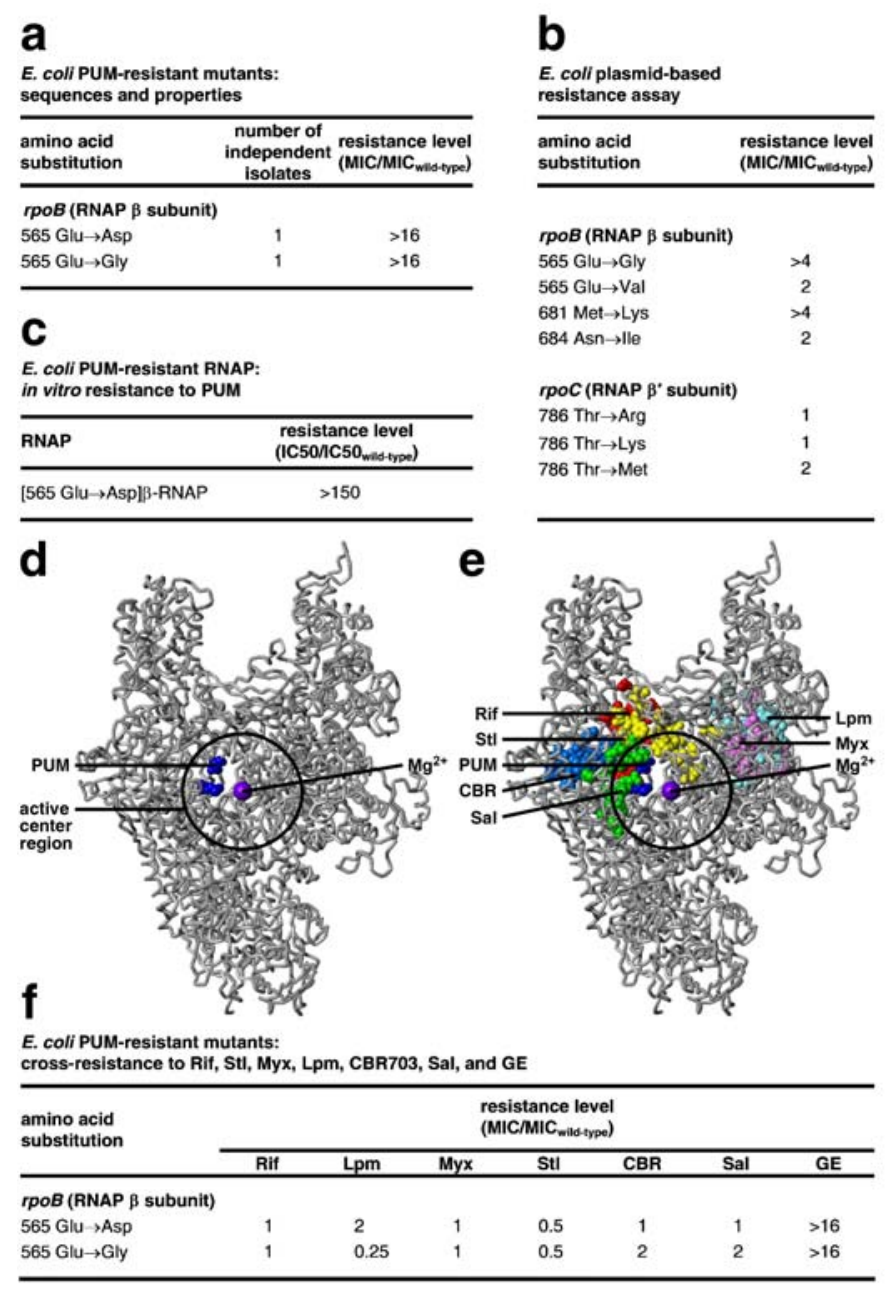

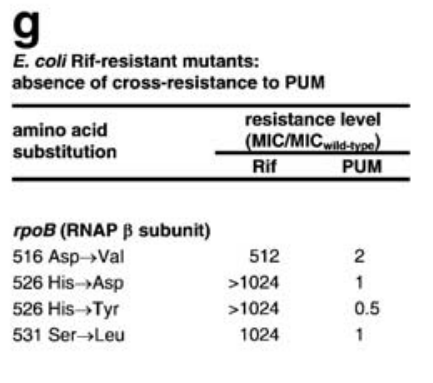

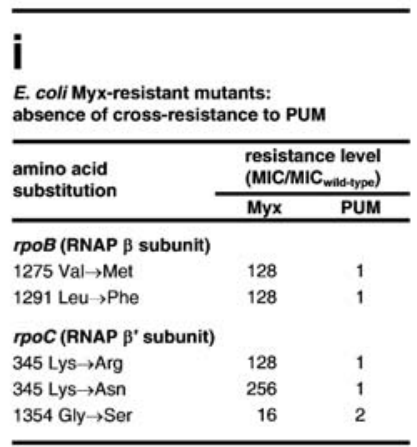

\section{$\mathbf{k}$}

E. coli CBR-resistant mutants: absence of cross-resistance to PUM

\begin{tabular}{lll}
\hline $\begin{array}{l}\text { amino acid } \\
\text { substitution }\end{array}$ & \multicolumn{2}{l}{$\begin{array}{l}\text { resistance level } \\
\text { (MIC/MIC }\end{array}$} \\
\cline { 2 - 3 } & CBR $\quad$ PUM \\
\hline
\end{tabular}

IPOB (RNAP $\beta$ subunit)

552 Pro $\rightarrow$ Met

$618 \mathrm{Gln} \rightarrow$ Leu

642 Ser $\rightarrow$ Phe

654 Asp $\rightarrow$ His

$657 \mathrm{Thr} \rightarrow$ lle n

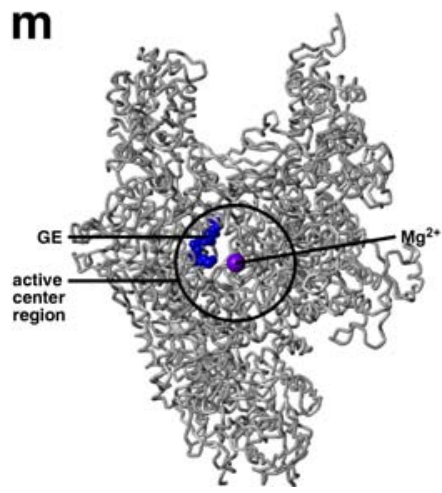

\begin{tabular}{lrl}
$\begin{array}{l}\text { E. coli GE-resistant mutants: } \\
\text { partial cross-resistance to PUM }\end{array}$ \\
\hline $\begin{array}{l}\text { amino acid } \\
\text { substitution }\end{array}$ & \multicolumn{2}{l}{$\begin{array}{l}\text { resistance level } \\
\text { (MIC/MIC }\end{array}$ with-trpe) } \\
\cline { 2 - 3 } & GE & PUM \\
\hline rpoB (RNAP B subunit) & & \\
565 Glu $\rightarrow$ Asp & $>16$ & 10 \\
566 Gly $\rightarrow$ Arg & 16 & 1 \\
566 Gly $\rightarrow$ Cys & 8 & 1 \\
566 Gly $\rightarrow$ Ser & 4 & 1 \\
684 Asn $\rightarrow$ Lys & $>16$ & 2 \\
684 Asn $\rightarrow$ Thr & 4 & 1 \\
\hline
\end{tabular}

h

\begin{tabular}{|c|c|c|}
\hline \multirow{2}{*}{$\begin{array}{l}\text { amino acid } \\
\text { substitution }\end{array}$} & \multicolumn{2}{|c|}{$\begin{array}{l}\text { resistance level } \\
\left.\text { (MIC/MIC } C_{\text {with-med }}\right)\end{array}$} \\
\hline & Lpm & PUM \\
\hline \multicolumn{3}{|c|}{ IPoB (RNAP $\beta$ subunit) } \\
\hline $1251 \mathrm{Tyt} \rightarrow$ Phe & 8 & 1 \\
\hline 1256 Gin $\rightarrow$ Glu & 8 & 1 \\
\hline 1256 Gln $\rightarrow$ Leu & 8 & 1 \\
\hline \multicolumn{3}{|c|}{$\operatorname{rpoC}$ (RNAP $\beta^{\prime}$ subunit) } \\
\hline $337 \mathrm{Arg} \rightarrow \mathrm{His}$ & 8 & 1 \\
\hline $337 \mathrm{Arg} \rightarrow$ Ser & 8 & 2 \\
\hline \multicolumn{3}{|c|}{$\begin{array}{l}\text { J } \\
\text { E. coli Stl-resistant mutants: } \\
\text { absence of cross-resistance to PUM }\end{array}$} \\
\hline \multirow{2}{*}{$\begin{array}{l}\text { amino acid } \\
\text { substitution }\end{array}$} & \multicolumn{2}{|c|}{$\begin{array}{l}\text { resistance level } \\
\text { (MIC/Mic }_{\text {wid-spe) }}\end{array}$} \\
\hline & $\mathrm{StI}$ & PUM \\
\hline \multicolumn{3}{|c|}{$r p o B$ (RNAP $\beta$ subunit) } \\
\hline $543 \mathrm{Ala} \rightarrow \mathrm{Val}$ & 64 & 1 \\
\hline 545 Phe $\rightarrow$ Cys & $>64$ & 0.5 \\
\hline \multicolumn{3}{|c|}{$r p o C$ (RNAP $\beta^{\prime}$ subunit) } \\
\hline 788 Leu $\rightarrow$ Met & 32 & 0.25 \\
\hline 1139 Pro $\rightarrow$ Arg & 8 & 1 \\
\hline 1139 Pro $\rightarrow$ Leu & 8 & 1 \\
\hline \multicolumn{3}{|l|}{ | } \\
\hline \multicolumn{3}{|c|}{$\begin{array}{l}\text { E. coli Sal-resistant mutants: } \\
\text { absence of cross-resistance to PUM }\end{array}$} \\
\hline \multirow[t]{2}{*}{$\begin{array}{l}\text { amino acid } \\
\text { substitution }\end{array}$} & \multicolumn{2}{|c|}{$\begin{array}{l}\text { resistance level } \\
\text { (MIC/MIC }_{\text {mid-oppe) }}\end{array}$} \\
\hline & Sal & PUM \\
\hline \multicolumn{3}{|c|}{ rpoB (RNAP $\beta$ subunit) } \\
\hline 675 Asp $\rightarrow$ Ala & $>256$ & 2 \\
\hline 677 Asn $\rightarrow$ Lys & $>256$ & 2 \\
\hline \multicolumn{3}{|c|}{$r p o C$ (RNAP $\beta^{\prime}$ subunit) } \\
\hline 738 Arg $\rightarrow$ Pro & 128 & 1 \\
\hline 779 Ala $\rightarrow$ Val & 256 & 1 \\
\hline 782 Gly $\rightarrow$ Ala & $>256$ & 0.25 \\
\hline
\end{tabular}

Extended Data Figure 4. Target of PUM: RNAP i+1 NTP binding site: results for Gram-negative bacterium E. coli.

a, E. coli spontaneous PUM-resistant mutants. b, Effects of S. pyogenes PUM-resistant mutants (sequences from Fig. 2b) when analyzed in E. coli plasmid-based resistance assay. Two substitutions confer moderate or higher $(\geq 4 \mathrm{x})$ resistance in E. coli plasmid-based resistance assay: $\beta 565 \mathrm{Glu} \rightarrow$ Gly and $\beta 681$ Met $\rightarrow$ Lys. c, PUM-resistant phenotype of purified E. coli RNAP containing $\beta 565 \mathrm{Glu} \rightarrow$ Asp. d, Location of E. coli PUM target (sequences from a-b) in three-dimensional structure of bacterial RNAP (colors as in Fig. 2c). e, Absence of overlap between PUM target (blue) and Rif (red), Lpm (cyan), Myx (pink), Stl (yellow), CBR (light blue), and Sal (green) targets. f, Absence of cross-resistance of E. coli PUM-resistant mutants (sequences from a-b) to Rif, Lpm, Myx, Stl, CBR, and Sal. g-l, Absence of crossresistance of E. coli Rif-, Lpm-, Myx-, Stl-, CBR-, and Sal-resistant mutants to PUM. m, Location of GE target (blue) in structure of bacterial RNAP. PUM target (d) shows partial overlap with GE target (m). n, Partial cross-resistance of E. coli GE-resistant mutants to PUM. 
a

RPo formation

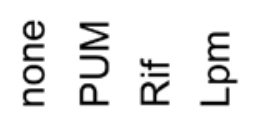

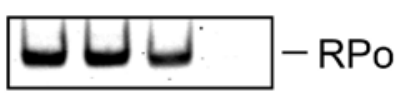

b

nucleotide addition

in initiation

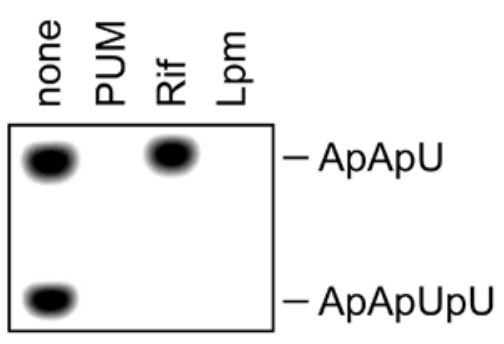

C

nucleotide addition

in elongation

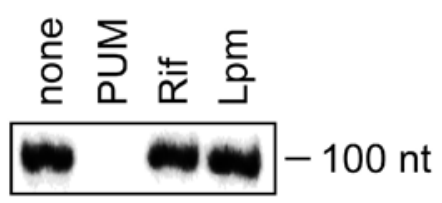

Extended Data Figure 5. Mechanism of PUM: inhibition of nucleotide addition

a, Absence of inhibition by PUM of formation of catalytically-competent RNAP-promoter open complex (RPo). b, Inhibition by PUM of nucleotide addition in transcription initiation. c, Inhibition by PUM of nucleotide addition in transcription elongation. 
bioRxiv preprint doi: https://doi.org/10.1101/106906; this version posted February 8, 2017. The copyright holder for this preprint (which was not certified by peer review) is the author/funder. All rights reserved. No reuse allowed without permission.

a
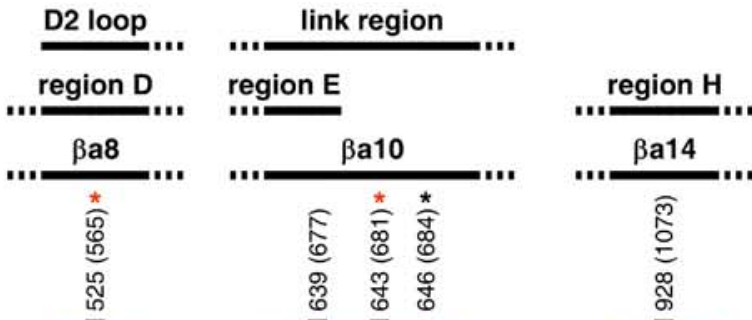

RPOB_ECOLI (562) ET

(674) DDA RAI GANMQR

RPOB_SALTY (562) ETEESPN

RPOB_KLEP7 (562) ET E EPN

RPOB_ENTCC (562) ET E EPN

RPOB_VIBCH (596) ET E EPN

RPOB_HAEIN (562) ETE E GPN

RPOB_CAMJE (577) ET E $E$ SON

RPOB_NEIG1 (589) ETE E $G$ PN

RPOB_STPMP (590) ET EPPN

RPOB_MORCA (572) ETAE SPN

RPOB_ACIBC (571) ET E EPN

RPOB_PSEAE (567) ET E EPN

RPOB_STAAU (517) ETEE EPN

RPOB_STAEQ (517) ETEE EPN

RPOB_ENTFA (525) ETE E $=P N$

RPOB STRP1 (522) ETEEGPN

RPOB_STRP2 (522) ET EEPN

RPOB_CDIFF (538) ET E EPN

RPOB_MYCTU (487) ET E EPN

RPOB_MYCA1 (487) ETEE EPN

RPOB_MYCA9 (483) ETEE GPN

RPOB_THEAQ (442) ET E EAN

RPOB_TTHER (442) ET E EAN

(674) DDA RAIY GANMQR

(674) DDA RAI GANMQR

(674) DDA RAI M GANMQR

(708) DDP RAI GANMQR

(675) DDA RAI GANMQR

(689) DDA RAI MSSNMQR

(701) DDP RAI GANMQR

(702) DDA RAI MANMQR

(684) DDA RAI Y GSNMQR

(683) DDA RAI GSNMQR

(679) DDA RAI GSNMQR

(631) DDSNRAI GANMQR

(631) DDSNAII GANMQR

(639) DDS RAI GANMQR

(636) DDSNRAI GANMQR

(636) DDSNRAI GANMQR

(653) DDA NAI GANMQR

(600) DDA RAI GANMQR

$(600)$ DDA RAI GANMQR

(596) DDA RAL IANMQR

(553) DDA RAI SSNMQT

(553) DDA NAI MSNMQT

\begin{tabular}{l|l|l} 
& & \\
$(1070)$ & HGN & SVI \\
$(1070)$ & HGN & SVI \\
$(1070)$ & HGN & GVI \\
$(1070)$ & HGN & GVI \\
$(104)$ & HGN & GVI \\
(1071) HGN & GVI
\end{tabular}

Gram-negative

(1099) HG

bacterial RNAP

RPOB_DEIRA (491) ETEE EAN (603) DDA NAI GSNMQS

RPA2_HUMAN (445) HT

RPB2_HUMAN (513) ETEE SHA (717) NQSERNTY SSAMGK

RPC2_HUMAN (483) DTEEEA (678) NOSERNTYLCAMGK

(1111) HGN GVV

(1111) HGN LVV

(1092) HGN

(1091) HGN

(1087) HG

(929) HGI

(929) HG

(928) HG

(925) HGN GVV

(925) HG

(942) HGN SVI

(889) HGN GVI

(889) HGN GVI

(885) HG

(843) HG

(843) HGN GVV

(902) HGN SVV

(831) HGF SIL

(939) HGd GTC

Deinococcus

bacterial RNAP

Human

RNAP I, II, III

b

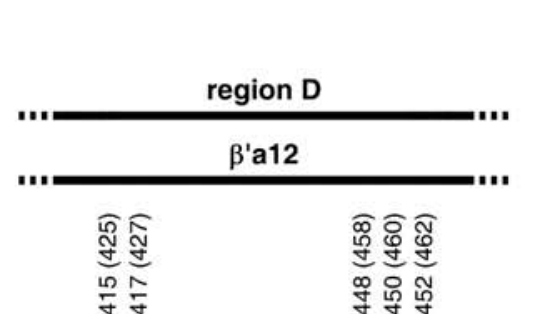

RPOC_ECOLI (422) LLN RPOC_SALTY (422) LLN RPOC_KLEP7 (422) LL RPOC_ENTCC (422) LLV RPOC_VIBCH (422) LL RPOC_HAEIN (423) LL? RPOC_CAMJE (444) ML RPOC_NEIG1 (424) MLN RPOC_STPMP (422) MLl RPOC_MORCA (424) LL RPOC_ACIBC (427) MLI RPOC_PSEAE (422) LL RPOC_STAAU (411) LL RPOC_STAEQ (411) LL RPOC_ENTFA (411) LL RPOC_STRP1 (412) LL RPOC_STRP2 (412) LI RPOC_CDIFF (411) LLN RPOC_MYCTU (497) LL RPOC_MYCA1 (497) LI RPOC_MYCA9 (497) LL? RPOC_THEAQ (701) LL RPOC_TTHER (701) LLY RPOC_DEIRA (718) LL RPA1_HUMAN (549) LLl RPB1_HUMAN (457) IFI RPC1_HUMAN (461) LF

年

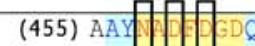

(455) AAY (455) AA (455) AAY (455) AAY (456) $\mathrm{AAF}$

(477) AAF

(457) AAF

(457) AAE

(455) AAY

(444) TAY

(444) TAY

(444) EA

(445) EA

(445) EAY

(444) TAY

(530) EA

(530) EAF

(530) EAF

(734) EAF

(734) EAF

(751) EAF

(583) KAY

(490) TPY

(494) TPY bridge helix
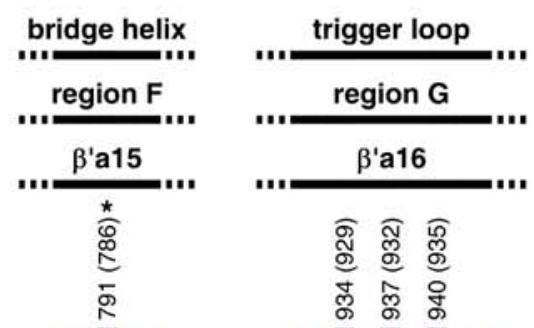

\section{(783) LAD ALK}

(783) LAD ALK

(783) LAD ALK

(783) LAD LLK

(783) LAD ALK

(784) LAD ALK

(781) LA ALK

(785) LAI ALK

(783) LAD ALK

(786) LAD ALK

(788) LAD ALK

(783) LAD ALK

(791) LAD ALK

(791) LAD ALK

(787) MT ALK

(788) MT ALK

(787) MTL LLK

(759) LAD AIR

(860) LAC ALR

(860) LAI ALR

(859) LAD ALR

(1081) GA ALR

(1081) GA ALR

(1099) GAC ALR

(975) IV

(847) LID AVK

(858) LV

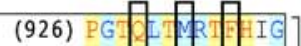

(926) PG (926) PG (926) PG L NRT IG (926) PG \& $D$ RIG (927) PG 
bioRxiv preprint doi: https://doi.org/10.1101/106906; this version posted February 8, 2017. The copyright holder for this preprint (which was not certified by peer review) is the author/funder. All rights reserved. No reuse allowed without permission.

Extended Data Figure 6. Interactions between RNAP and PUM: sequence alignments.

Locations of residues that contact PUM in the sequences of RNAP $\beta$ subunit (a) and RNAP $\beta^{\prime}$ subunit (b). Sequence alignments for $\beta$ and $\beta^{\prime}$ subunits of bacterial RNAP (top 24 sequences in each panel) and corresponding subunits of human RNAP I, RNAP II, and RNAP III (bottom three sequences in each panel), showing locations of RNAP residues that contact PUM (black rectangles; numbered as in $S$. pyogenes and, in parentheses, as in E. coli; identities from Fig. 4a), locations of residues at which substitutions conferring PUM-resistance are obtained in both S. pyogenes and E. coli (red asterisks; identities from Fig.. 2b and Extended Data Fig. 4a-b), locations of residues at which substitutions conferring PUM-resistance are obtained in S. pyogenes but not E. coli (black asterisks; identities from Fig.. 2b and Extended Data Fig. 4a-b), locations of RNAP structural elements ${ }^{71-72}$ (top row of black bars), and RNAP conserved regions ${ }^{73-75}$ (next two rows of black bars). Species are as follows: E. coli (ECOLI), Salmonella typhimurium (SALTY), Klebsiella pneumoniae (KLEP7), Enterococcus cloacae (ENTCC), Vibrio cholerae (VIBCH), Haemophilus influenzae (HAEIN), Campylobacter jejuni (CAMJE), Neisseria gonorrhoeae (NEIG1), Stenotrophomonas maltophilia (STPMP), Moraxella catarrhalis (MORCA), Acinetobacter baumannii (ACIBC), Pseudomonas aeruginosa (PSEAE), Staphylococcus aureus (STAAU), Staphylococcus epidermidis (STAEQ), Enterococcus faecalis (ENTFA), Streptococcus pyogenes (STRP1), Streptococcus pneumoniae (STRP2), Clostridium difficile (CDIFF), Mycobacterium tuberculosis (MYCTU), Mycobacterium avium (MYCA1), Mycobacterium abscessus (MYCA9), Thermus aquaticus (THEAQ), Thermus thermophilus (THETH), Deinococcus radiodurans (DEIRA), and Homo sapiens (HUMAN). 


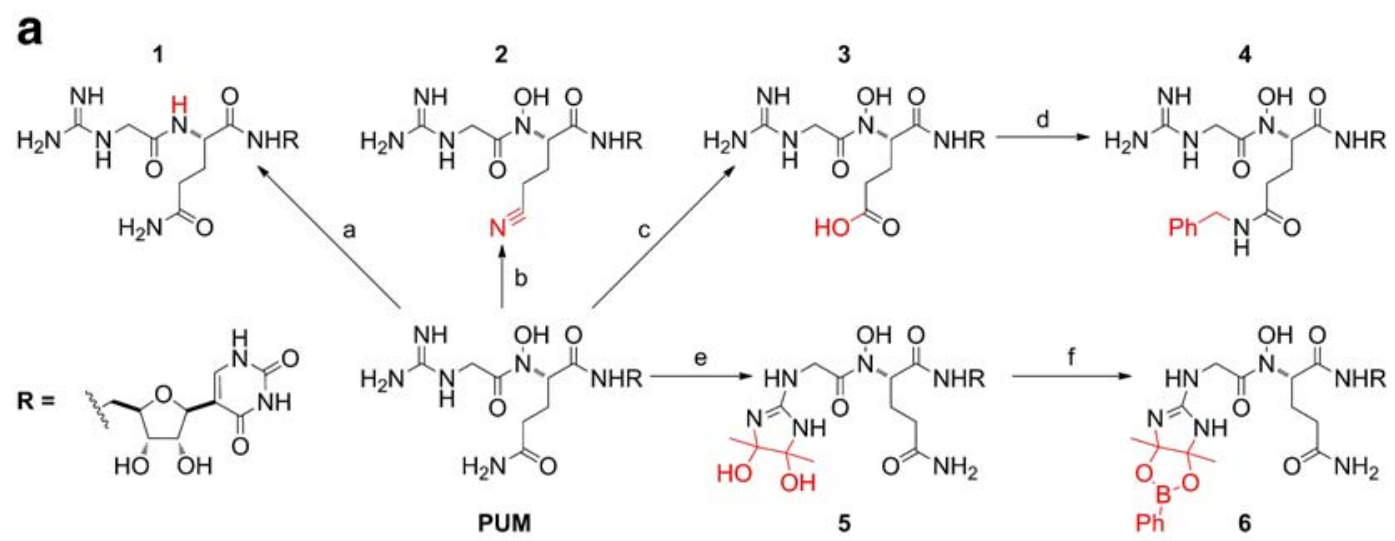

(a) $\mathrm{TiCl}_{3}, 1 \mathrm{M} \mathrm{NaOAc}$ (pH 7), RT 2h, 100\%; (b) PdCl $, 1: 1 \mathrm{ACN}: \mathrm{H}_{2} \mathrm{O}, \mathrm{RT} 2 \mathrm{~h}, 90 \%$; (c) $0.1 \%$ TFA, RT 3 days, $100 \%$;

(d) $\mathrm{BnNH}_{2}$, DMF + PyBOP, RT 30min, $100 \%$; (e) 2,3-butanedione, $10 \mathrm{mM} \mathrm{NH}_{4} \mathrm{OAc}$ (pH 8), RT 30min, $100 \%$;

(f) $\mathrm{PhB}(\mathrm{OH})_{2}, 10 \mathrm{mM} \mathrm{NH}_{4} \mathrm{OAc}$ (pH 8), RT 2h, 100\%

b

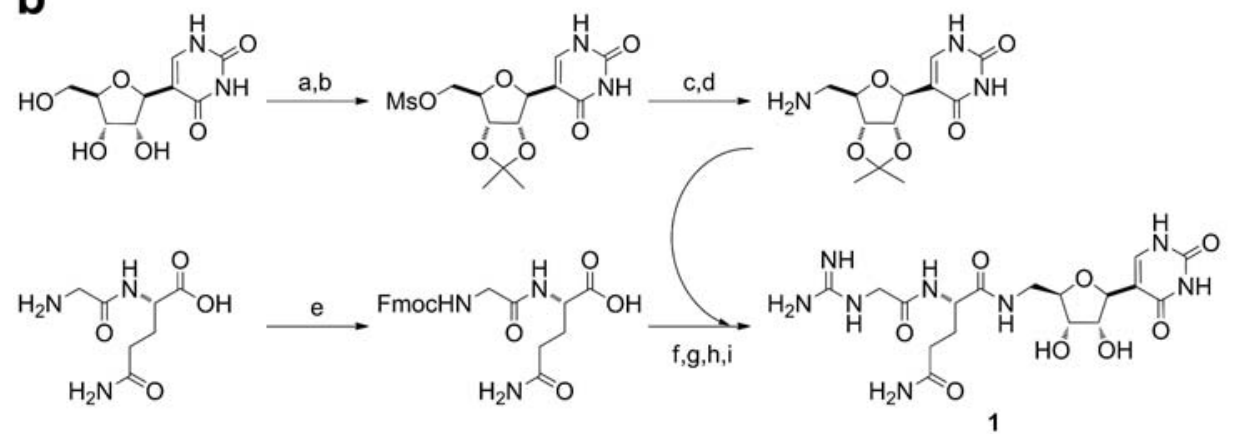

(a) $\mathrm{Me}_{2} \mathrm{C}(\mathrm{OMe})_{2}, \mathrm{DMF}, \mathrm{HCl}, \mathrm{RT} 5 \mathrm{~h}, 100 \%$; (b) $\mathrm{MsCl}, \mathrm{Pyr}, 0^{\circ} \mathrm{C}+\mathrm{RT} 16 \mathrm{~h}, 95 \%$; (c) $\mathrm{NaN}_{3}, \mathrm{DMF}, 100^{\circ} \mathrm{C} 4 \mathrm{~h}, 86 \%$; (d) $\mathrm{Me}_{3} \mathrm{P}, \mathrm{THF}+\mathrm{H}_{2} \mathrm{O}, \mathrm{RT} 2 \mathrm{~h}, 95 \%$; (e) $\mathrm{Na}_{2} \mathrm{CO}_{3}+\mathrm{FmocCl}$, dioxane $+\mathrm{H}_{2} \mathrm{O}, \mathrm{RT}$ o/n, $100 \%$;

(f) DCC-HOBT, dry DMF, RT o/n, $95 \%$; (g) piperidine, DMF, $25^{\circ} \mathrm{C} 10 \mathrm{~min}, 100 \%$;

(h) 3,5-dimethylpyrazole-1-carboxyamidine, $\mathrm{MeOH}, \mathrm{RT}$ o/n $+65^{\circ} \mathrm{C} 6 \mathrm{~h}, 100 \%$;

(i) $7: 3 \mathrm{AcOH}-\mathrm{H}_{2} \mathrm{O}, \mathrm{RT}$ o/n $+50^{\circ} \mathrm{C}$ 10h under $\mathrm{Ar}, 100 \%$

C

RNAP-inhibitory activity (E. coli RNAP)

\begin{tabular}{lc}
\hline PUM derivative & $\begin{array}{c}\text { IC50 } \\
(\boldsymbol{\mu M})\end{array}$ \\
\hline PUM & 0.3 \\
1 & 4 \\
2 & $>50$ \\
3 & 4 \\
4 & 1 \\
5 & $>50$ \\
6 & $>50$ \\
\hline
\end{tabular}

d

antibacterial activity (S. pyogenes)

\begin{tabular}{lc}
\hline PUM derivative & $\begin{array}{c}\text { MIC } \\
(\boldsymbol{\mu} \mathbf{g} / \mathbf{m l})\end{array}$ \\
\hline PUM & 2 \\
1 & 16 \\
2 & $>64$ \\
3 & 16 \\
4 & 16 \\
5 & $>64$ \\
6 & $>64$ \\
\hline
\end{tabular}

Extended Data Figure 7. Semi-synthesis, synthesis, and analysis of PUM derivatives.

a, Semi-synthesis of PUM derivatives lacking PUM N-hydroxy group (1), having alterations of PUM glutaminyl sidechain (2-4), or having alterations of PUM guanidinyl sidechain (5-6). b, Synthesis of PUM derivative lacking PUM N-hydroxy group (1). c-d, RNAP inhibitory activities and antibacterial activities of PUM derivatives. 
bioRxiv preprint doi: https://doi.org/10.1101/106906; this version posted February 8, 2017. The copyright holder for this preprint (which was not certified by peer review) is the author/funder. All rights reserved. No reuse allowed without permission.

Extended Data Table 1. Selectivity of RNAP-inhibitory activity

\begin{tabular}{|c|c|c|}
\hline enzyme & IC50 $(\mu \mathrm{M})( \pm$ SEM) & selectivity ratio \\
\hline \multicolumn{3}{|c|}{ promoter-dependent transcription } \\
\hline \multicolumn{3}{|l|}{ E. coli RNAP } \\
\hline $6.25 \mu \mathrm{M}$ UTP & 0.1 & [1] \\
\hline $50 \mu \mathrm{M}$ UTP & 2 & [1] \\
\hline $250 \mu \mathrm{M}$ UTP & 8 & [1] \\
\hline \multicolumn{3}{|c|}{ human RNAP I } \\
\hline $6.25 \mu \mathrm{M}$ UTP & $>50$ & $>500$ \\
\hline $50 \mu \mathrm{M}$ UTP & ND & ND \\
\hline $250 \mu \mathrm{M}$ UTP & ND & ND \\
\hline \multicolumn{3}{|c|}{ human RNAP II } \\
\hline $6.25 \mu \mathrm{M}$ UTP & 1 & 10 \\
\hline $50 \mu \mathrm{M}$ UTP & 7 & 4 \\
\hline $250 \mu \mathrm{M}$ UTP & $>20$ & $>3$ \\
\hline \multicolumn{3}{|c|}{ human RNAP III } \\
\hline $6.25 \mu \mathrm{M}$ UTP & 9 & 90 \\
\hline $50 \mu \mathrm{M}$ UTP & ND & ND \\
\hline $250 \mu \mathrm{M}$ UTP & ND & ND \\
\hline \multicolumn{3}{|c|}{ promoter-independent transcription } \\
\hline \multicolumn{3}{|l|}{ E. coli RNAP } \\
\hline $1.56 \mu \mathrm{M}$ UTP & $0.9( \pm 0.1)$ & [1] \\
\hline $25 \mu \mathrm{M}$ UTP & $4( \pm 0.7)$ & [1] \\
\hline $400 \mu \mathrm{M}$ UTP & $10( \pm 2)$ & [1] \\
\hline \multicolumn{3}{|c|}{ HeLa nuclear extract (human RNAP I / II / III) } \\
\hline $1.56 \mu \mathrm{M}$ UTP & $4( \pm 0.1)$ & 4 \\
\hline $25 \mu \mathrm{M}$ UTP & $15( \pm 6)$ & 4 \\
\hline $400 \mu \mathrm{M}$ UTP & $51( \pm 30)$ & 5 \\
\hline
\end{tabular}


bioRxiv preprint doi: https://doi.org/10.1101/106906; this version posted February 8, 2017. The copyright holder for this preprint (which was not certified by peer review) is the author/funder. All rights reserved. No reuse allowed without permission.

Extended Data Table 2. Antibacterial activity in vivo (mouse S. pyogenes peritonitis model; 7 day survival)

\begin{tabular}{|c|c|c|c|c|c|}
\hline \multirow{2}{*}{\multicolumn{2}{|c|}{$\begin{array}{l}\text { intravenous (iv) administration, } \\
10 \mathrm{~min} \text { and } 6 \mathrm{~h} \text { post-infection }\end{array}$}} & \multirow{2}{*}{\multicolumn{2}{|c|}{$\begin{array}{l}\text { intravenous (iv) administration, } \\
10 \text { min post-infection }\end{array}$}} & \multirow{2}{*}{\multicolumn{2}{|c|}{$\begin{array}{l}\text { subcutaneous (sc) administration, } \\
10 \text { min post-infection }\end{array}$}} \\
\hline & & & & & \\
\hline $\begin{array}{l}\text { PUM total dose } \\
(\mathrm{mg} / \mathrm{kg})\end{array}$ & survivors / total & $\begin{array}{l}\text { PUM total dose } \\
(\mathrm{mg} / \mathrm{kg})\end{array}$ & survivors / total & $\begin{array}{l}\text { PUM total dose } \\
(\mathrm{mg} / \mathrm{kg})\end{array}$ & survivors / total \\
\hline 50 & $7 / 8$ & 40 & $5 / 8$ & 40 & $6 / 8$ \\
\hline 20 & $6 / 8$ & 16 & $4 / 8$ & 16 & $2 / 8$ \\
\hline 8 & $5 / 8$ & 6.4 & $0 / 8$ & 6.4 & $1 / 8$ \\
\hline 3.2 & $0 / 8$ & 2.56 & $2 / 8$ & 2.56 & $1 / 8$ \\
\hline \multirow[t]{2}{*}{0} & $0 / 8$ & 1.024 & $0 / 8$ & 1.024 & $0 / 8$ \\
\hline & & 0 & $0 / 8$ & 0 & $0 / 8$ \\
\hline
\end{tabular}


bioRxiv preprint doi: https://doi.org/10.1101/106906; this version posted February 8, 2017. The copyright holder for this preprint (which was not certified by peer review) is the author/funder. All rights reserved. No reuse allowed without permission.

Extended Data Table 3. Data collection and refinement statistics.

\begin{tabular}{|c|c|c|}
\hline & $\begin{array}{l}\text { RPo-GpA-PUM } \\
\qquad(5 \times 21)\end{array}$ & $\begin{array}{c}\text { RPo-GpA-CMPcPP } \\
(5 \times 22)\end{array}$ \\
\hline \multicolumn{3}{|l|}{ Data collection } \\
\hline Space group & $\mathrm{C} 2$ & $\mathrm{P} 2_{1}$ \\
\hline \multicolumn{3}{|l|}{ Cell dimensions } \\
\hline$a, b, c(\AA)$ & $186.8,103.1,296.2$ & $186.4,104.3,297.3$ \\
\hline$\alpha, \beta, \gamma\left({ }^{\circ}\right)$ & $90.0,98.7,90.0$ & $90.0,98.4,90.0$ \\
\hline Resolution (Å) & $40.00-3.30(3.36-3.30)^{\star}$ & $50.00-3.35(3.41-3.35)^{*}$ \\
\hline$R_{\text {sym }}$ or $R_{\text {merge }}$ & $0.138(0.633)$ & $0.197(>1.0)$ \\
\hline$I / \sigma(l)$ & $8.4(1.7)$ & $7.7(1.8)$ \\
\hline Completeness (\%) & $0.920(0.874)$ & $0.956(0.891)$ \\
\hline Redundancy & $3.4(3.4)$ & $5.3(5.3)$ \\
\hline \multicolumn{3}{|l|}{ Refinement } \\
\hline Resolution (Å) & $50.00-3.32$ & $50.00-3.33$ \\
\hline No. reflections & 70085 & 147976 \\
\hline$R_{\text {work }} / R_{\text {tree }}$ & $0.232 / 0.280$ & $0.208 / 0.250$ \\
\hline \multicolumn{3}{|l|}{ Number of atoms } \\
\hline Protein/DNA/RNA & 28662 & 56787 \\
\hline Ligand/ion & 42 & 76 \\
\hline Water & 35 & 0 \\
\hline \multicolumn{3}{|l|}{$B$ factors } \\
\hline Protein & 61.6 & 41.8 \\
\hline Ligand/ion & 31.8 & 21.0 \\
\hline Water & 34.3 & - \\
\hline \multicolumn{3}{|l|}{ R.m.s deviations } \\
\hline Bond lengths $(\AA ̊)$ & 0.002 & 0.007 \\
\hline Bond angles $\left(^{\circ}\right)$ & 0.542 & 0.834 \\
\hline
\end{tabular}

*Values in parentheses are for highest-resolution shell. 